\title{
METHODS OF
}

ATTRACTING BIRDS

CUL BLRT Y. TRAFTON

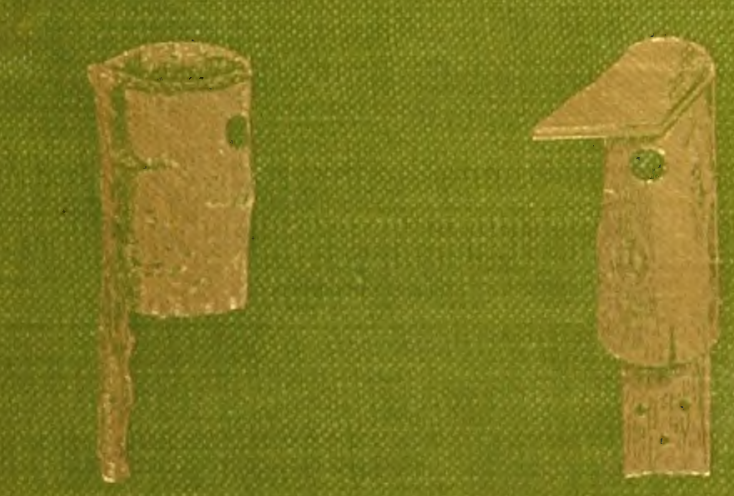




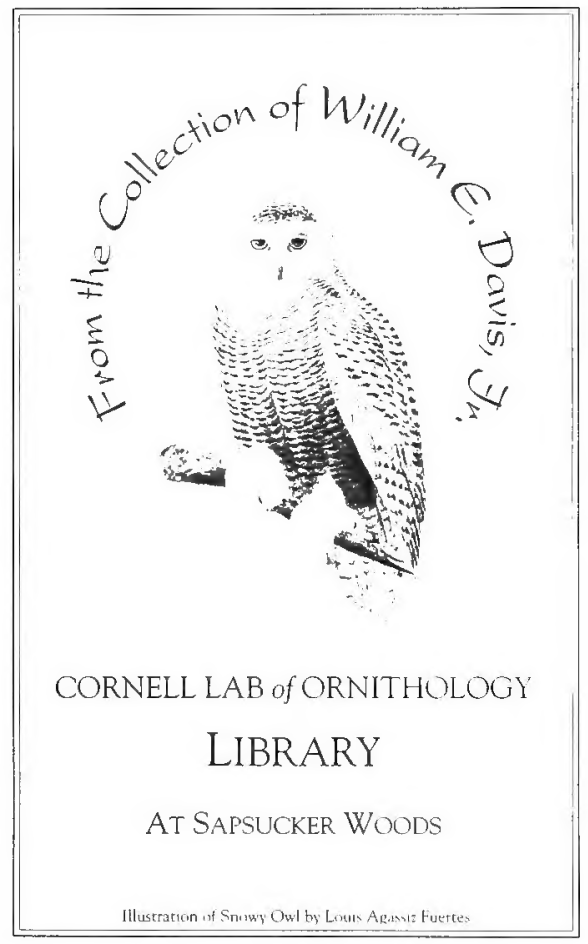


DATE DUE

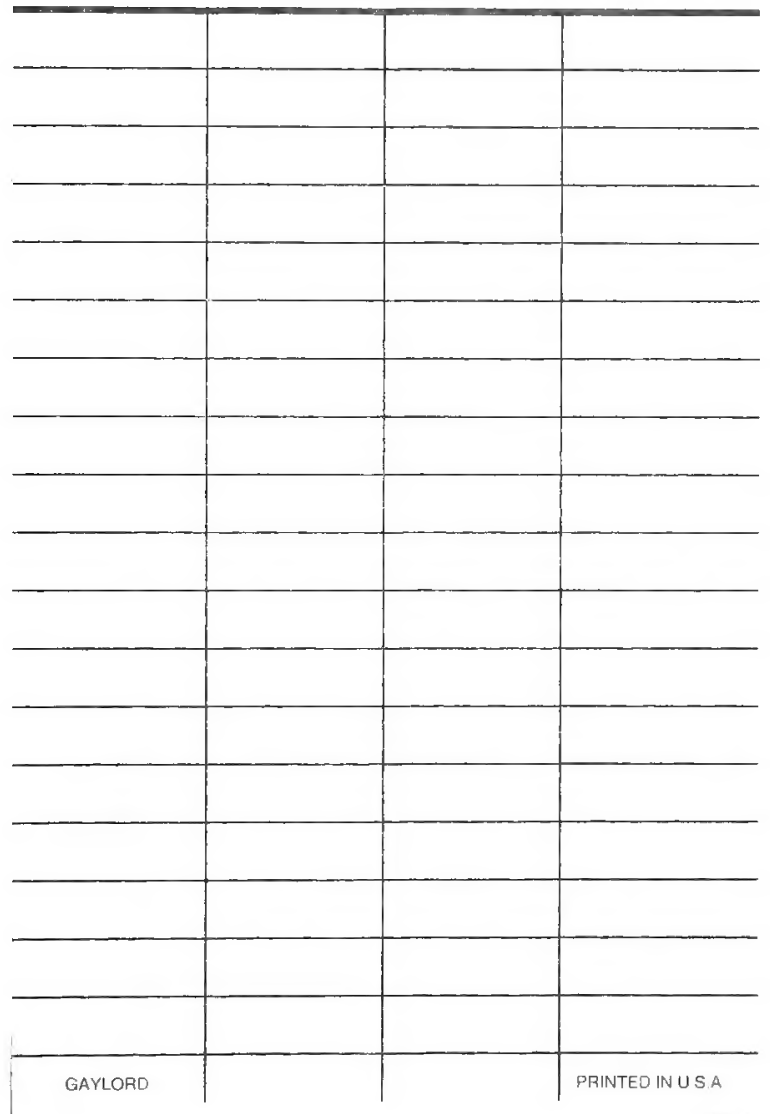




\section{Cornell University Library}

The original of this book is in the Cornell University Library.

There are no known copyright restrictions in the United States on the use of the text.

http://www.archive.org/details/cu31924090259239 


\section{METHODS OF ATTRACTING BIRDS}






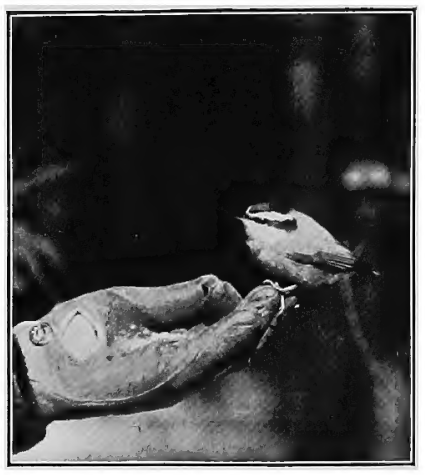

RED-BREASTED NUTHATCH

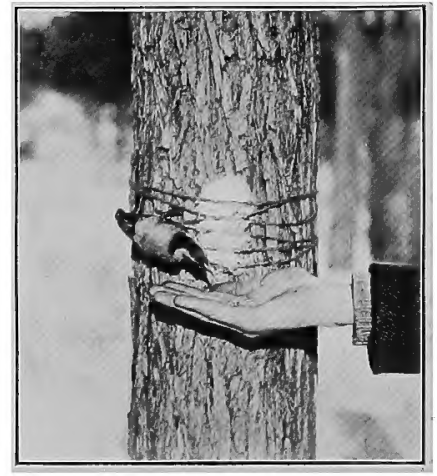

WHITE-BREASTED NUTHATCH

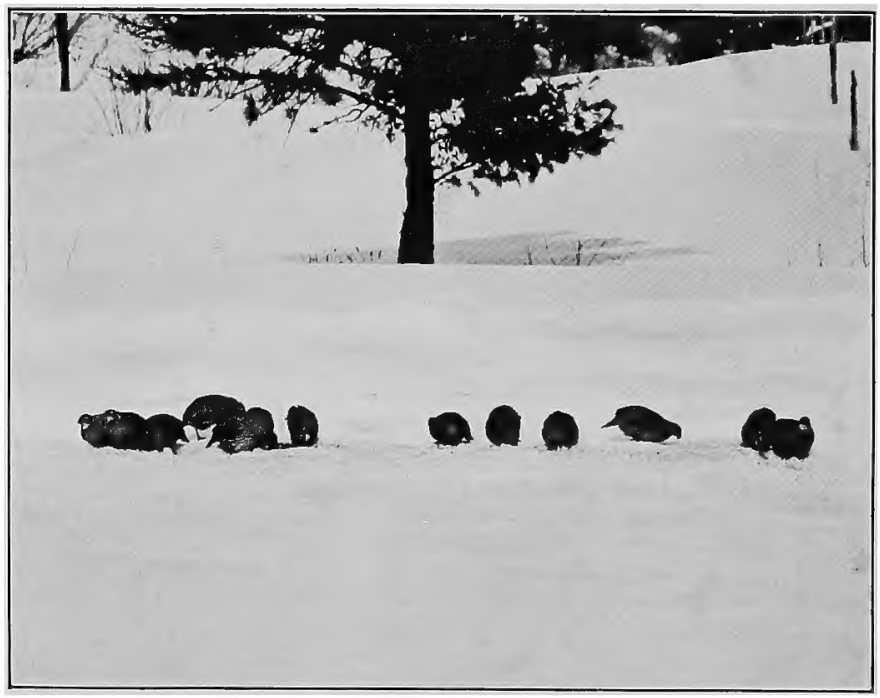

BOB-WHITE AT FEEDING-STATION 




\section{METHODS OF \\ ATTRACTING BIRDS}

BY

GILBERT H. TRAFTON

Supervisor of Nature-Study, Passaic, N. J.

WITH ILLUSTRATIONS

PUBLISHED UNDER THE AUSPICES OF

THE NATIONAL ASSOCIATION OF

AUDUBON SOCIETIES

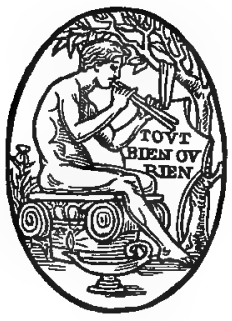

BOSTON AND NEW YORK

HOUGHTON MIFFLIN COMPANY

(Cbe Aituratide prega Cambridge 


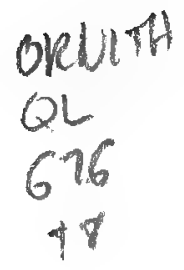

COPYRIGHT, I9IO, BY GILBERT H. TRAFTON ALL RIGHTS RESERVED

Published September rqro 


\section{TO THE AUDUBON SOCIETIES \\ IN APPRECIATION OF THEIR WORK IN \\ THE CAUSE OF BIRD-PROTECTION \\ THIS BOOK IS DEDICATED}





\section{PREFACE}

THe importance of attracting birds around our homes was first impressed upon the author through his experience with children in connection with the work in nature-study in the public schools. This was encouraged chiefly from the child's standpoint, on account of the educative value of this kind of work on the child. Furthermore, from the standpoint of the birds, this means of encouraging and protecting them is a very efficient one, which may be applied by all birdlovers, adults as well as children.

Hence this book has been written from two view-points, that of birds and that of human beings; for the protection of the former and the pleasure of the latter.

The author has not attempted to restrict himself to his own experiences, but has drawn freely upon the experiences of any who could be reached. And, indeed, the chief value of these pages lies in the fact that they represent the results of so many observers, giving a brief summary of the work that is being done throughout the country.

To those who have assisted him in the preparation of this book, the author wishes to extend 
his sincere thanks. The columns of "Bird-Lore" have furnished much valuable material, other magazines and bird-books have been consulted, and through personal correspondence much of value has been acquired. From these same sources have been secured many of the illustrations, credit for which is given in connection with each photograph. A list of those to whose contributions in any of these ways the author has had access, is printed in an appendix.

The author takes special pleasure in acknowledging his indebtedness to Mr. Edward Howe Forbush, whose wide experience renders his various publications most helpful, and who has read the entire manuscript, offering many valuable suggestions.

Special thanks, also, are due Edward Uehling for many valuable suggestions and results which his ingenuity and persistence have made possible.

A brief summary has been given of some very interesting experiments carried on in Germany by Baron von Berlepsch, whose work has been described by Martin Hiesemann in a book entitled "How to Attract and Protect Wild Birds," which has now appeared in an English translation.

For illustrations used in this book thanks are due to Messrs. Ernest Harold Baynes, J. S. 
Becker, Clarence D. Brown, Edwin C. Brown, Frank M. Chapman, C. E. Hamilton, John D. Haney, Robert W. Hegner, D. Lange, and Laurence J. Webster, to Dr. A. K. Fisher, The Macmillan Company, "Bird-Lore," and "Forest and Stream," and especially to Mr.E.H.Forbush, who has furnished the drawings for a number of cuts originally published in his "Useful Birds and their Protection," as well as his photograph of the screech owl in its nesting-box.

The author will welcome any correspondence regarding experiences along the lines here described, either as suggestions regarding the improvement of any methods here given, or as additional information.

The preparation of this book was carried on with the support of the National Association of Audubon Societies after consultation with its officers, with whose express approval it is now issued. 



\section{CONTENTS}

\section{CHAPTER I}

The Need and Value of Attracting Brrda . . . 1

\section{CHAPTER II}

Nesting-houses . . . . . . . . . . . . . 13

\section{CHAPTER III}

Attracting the Winter Birds . . . . . . 80

\section{CHAPTER IV}

Drinking- and Bathing-fountains . . . . . . 115

\section{CHAPTER V}

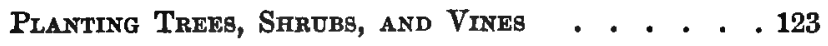

\section{CHAPTER VI}

BIRD-PROTECTION IN SCHOOLS . . . . . . . 136

\section{CHAPTER VII}

BIRD-PHOTOGRAPHY . . . . . . . . . . 155 APPENDIX . . . . . . . . . . . . . 165 INDEX . . . . . . . . . . . 169 



\section{ILLUSTRATIONS}

Red-Breasted Nuthatch, Perched oN haNd Photograph by Laurence J. Webster

White-Breasted Nuthatch, Feeding From HAND

Photograph by Edwin C. Brown

Bob-White at a Feeding-station provided By the High-school Boys at Stoneham, Mass. Photoyraph by John Tresilian

Bluebird at Entrance to Nesting-Box . . . . . 14 Photograph by Author

House Wren and Tomato-can House . . . . . 14 Photograph by Author

Tref Swallow at Nesting-Box . . . . . . . 14 Photograph by W. H. Phillips

Martin-house, accommodating Five Thousand Birds 14 Photograph by C. E. Hamilton

Hollow Limb Box . . . . . . . . . . 16

Brrch-Bark HoUse . . . . . . . . . . . 17

Bluebird Box . . . . . . . . . . . . 18

Obgervation Box, closed . . . . . . . . . 20

Obgervation Box, OPEN . . . . . . . . . . 21 
Two Virws of a Martin Colony . . . . . . . 22 Photograph by J. S. Becker

Clay Negting-boxes . . . . . . . . . . . . 22

Photograph by Robert W. Hegner

Box with Slmorg Cover . . . . . . . . 23

Wood Ducr Houge . . . . . . . . . . . 29

Barrel House for Martins . . . . . . . . 39

Designed by E. H. Forbush

Screech OWL in Negting-Box . . . . . . . . 40

Photograph by E. H. Forbush

Shelf for Pherbe's Nest . . . . . . . . . 54

Drawn by $E$. H. Forbush

Tin or Zinc Cat-guards . . . . . . . . . . . 62

Drawn by E. H. Forbush

Barbed-Wire Cat-guard . . . . . . . . . . . 63

A Cat-Proof Fence . . . . . . . . . . . . 64

Song Sparrow at Lunch-counter . . . . . . 80

Downy WoOdpecker at Lunch-COUNTER . . . . 80

Chickader feeding from Hand . . . . . . 80

Four photographs by Author

Hermt Throgh at Lunch-counter . . . . . 80

A Bird's Tepee, made of Bean-poles with the Vines STILI ATtached . . . . . . . . . . . . . . 80

Photograph by Frank M. Chapman 
A Selt-supplying Feed-box . . . . . . . . . 80 Photograph by Edwin C. Brown

Sheiter for Brrds' Food (Fifteen Birds feedng, -

Song Sparrows, Tree Sparrows, Juncos) . • • 90

Photograph by William C. Horton

Window and Moving Food-shelves . . . . . 90 Photograph by Author

Feeding-house . . . . . . . . . . . . . . 101

From Berlepsch's "Der Gesamte Vogelschutz"

Food-Bell . . . . . . . . . . . . . . . . 102 From Berlepsch

Crosg-section Diagram of Birdg' Drnnking-fountan 117

Bird Fountan of C. D. Brown, Rutherford, N. J. 118

Bird Fountain in Yard of Franklin School, Pas-

BAIC, N. J. . . . . . . . . . . . . . . . 118 Photograph by Author

A Birds' Bath . . . . . . . . . . . . . . . 118 Photograph by Robert W. Hegner

Fruits Valuable as Bird-Food . . . . . . . . 127

Drawn by $\boldsymbol{E}$. H. Forbush

Children with Bird-houges, Lincoln School, PagSAIC, N. J. . . . . . . . . . . . . . • . 138

Photograph by Author

Brrd-houses made by Childrex of Public School No. 5, Bronx, New York City . . . . . . . 138 Photograph by John D. Haney, Principal 



\section{METHODS \\ OF ATTRACTING BIRDS}

\section{CHAPTER I}

THE NEED AND VALUE OF ATTRACTING BIRDS

THE reasons for attracting birds around our homes are twofold: first, the protection of the birds, and second, the resulting benefits that accrue to man, both on account of the great economic value of these birds to the farmer in his struggle with injurious insects, and also on account of the pleasure derived in helping and watching the birds.

During the winter season the opportunity offered for studying birds, at a time when Nature's activities are at their lowest ebb, is most welcome, and especially so because the birds may become so tame that they will feed from the window-sills while one is sitting just inside the window, thus affording opportunity to observe them at close range. 


\section{Destruction of Nesting-sites}

With the rapid increase in population in our cities and large towns, and their corresponding growth countryward, roadside shrubbery, orchards, decaying trees, and other nesting-sites are steadily disappearing as the real-estate agent extends his operations and begins to "improve"the land.

In the suburbs of cities, birds that nest in cavities are forced to hunt very closely to find a nesting-site. One spring, on entering a little shed which had remained closed for several months, the author found inside two pairs of dead bluebirds, which had evidently entered a knot-hole on the side of the building in their quest for a nesting-place, and had not been able to find their way out again. Wood ducks, screech owls, and flickers have been found dead in stove-pipes leading from tile chimneys in summer cottages and workshops. Bluebirds have been found drowned in water-barrels in the country, having entered through holes in the conductors.

Even in the country, sometimes the farmer thinks he must clear up the shrubbery and the tangles by the roadside and along the fences, which, however, furnish one excellent means 
NEED AND VALUE OF ATTRACTING BIRDS 3 of inducing the birds to remain and nest, and thus aid the farmer in his struggle with the insects.

The excessive demand for wood, both for fuel and for building, is causing the rapid cutting of trees both in large forests and in small lots, as a result of which the birds which seek shelter or nesting-sites in the woods are each year finding it more difficult to secure the conditions neeessary for their maintenance.

\section{Winter Protection}

The winter is a season, when, from the birds' standpoint, assistance in obtaining food is particularly welcome. When heavy snows lie on the ground, much of the supply of the seed-eating birds is hidden; and when the tree-trunks are covered with ice, insect-eating birds find it difficult to break through this coating, to secure insects and their eggs in the bark beneath. Under ordinary conditions our birds can withstand quite cold weather if they are well supplied with food; but this is digested so quickly that birds require a large amount and frequent access to it. Many birds perish from exposure to severe storms and weather, as well as from starvation, so that shelter as well as food is necessary to protect the winter birds. 


\section{Winter Mortality among Birds}

In order to emphasize the need of furnishing food and shelter for the winter birds as a practical means of protecting them from the inclemencies of the elements, a few statistics are given showing the effect of the winter of 1903 and 1904 upon the birds. This summary' is taken from a report by Edward Howe Forbush, based upon observations of seventy-five correspondents in Massachusetts, and fifteen from neighboring states. While this winter was an unusually severe one, yet these reports suggest the dangers to which birds are exposed during average winters, as well as the extreme perils of an occasional severe one.

During the first half of the winter birds were present in about their usual numbers, but as the severity of the weather increased the number of birds began to decrease, till about the end of the winter a very noticeable mortality was universally reported, and many birds were found dying of cold and hunger; and it was the opinion of those best fitted to judge that most of the birds which usually wintered there were either starved or frozen.

Among the greatest sufferers were the bobwhite, partridge, meadowlark, and flicker. In 
NEED AND VALUE OF ATTRACTING BIRDS 5

some localities the bob-white was apparently entirely exterminated, Mr. Forbush estimating that it had been reduced at least ninety-five per cent.

\section{Effect of feeding Birds}

The important part of the report is that which shows the protection afforded the birds by feeding them. Mr. Forbush says : "Reports that have come in from all portions of the state lead to the conclusion that large numbers of birds have been saved from starvation during the winter by people who have fed them. Most of the reports indicate that where birds were well fed, nuthatches and downy woodpeckers wintered very well; elsewhere they had a hard time. The trees were frozen so hard that drilling into them for insects was difficult, and woodpeckers have been operating on cedar rails and posts, and under the eaves of $\log$ and slab shanties in the woods. My own experience indicates that nearly all birds were scarce except where they were fed. Many people were feeding them, and they were attracted to these feeding-places, so that they appeared at such places to be in their usual numbers.

"The mortality seems to have been least among those familiar species that seek the habitations of man, thus finding the food exposed for them; and greatest among those like the mead- 
owlark and quail, that have most reason to fear man and therefore usually keep at a safe distance from human habitations."

Value of attracting Birds to the Farm

The farmer will find it a profitable business undertaking to make efforts to attract birds around his dwellings and orchard for the return which the birds give in destroying the insects that attack his crops. The real practical value to the farmer, from a business standpoint, of taking the steps necessary to encourage the presence of birds around the farm, is generally unappreciated. The progressive farmer does not begrudge the expense entailed in securing a spraying outfit, and the annual outlay involved in its use. With an expense so small that it hardly needs to be taken into account, the farmer may have very efficient insect-destroyers in the flocks of birds which may be attracted around the farm, - destroyers which do not require the time and supervision of the farmer to render them effective, but which of their own accord are constantly at work from sunrise until sunset, freeing the farm from its insect enemies. Some enterprising farmers are taking steps to attract birds around their farms. A successful fruit-grower in Georgia has erected a series of tall poles in his 
peach orchard, from which are hung gourds for the martins to nest in.

Not only may there be freedom from large insect outbreaks and the expense involved in keeping them in check, but under the ordinary conditions, when insects may do only slight damage, undoubtedly even this slight amount is lessened and the quantity of crops harvested correspondingly increased, through the activities of the birds.

There are on record enough instances to show the resulting benefits, when systematic efforts are made to encourage the presence of birds.

Mr. Forbush cites an instance of four young apple trees which were infested with plant-lice. Two of the trees, which were located near houses containing families of bluebirds and chickadees, were almost entirely cleared of the lice by these birds, while the other two, which were some distance away, finally died from the effect of the pests.

Evidence of the value of attracting birds also comes from Germany, where systematic experiments have been carried out. In the spring of 1905 the larvæ of a moth attacked a large wood, near Eisenach, and stripped it almost entirely of its foliage; while in a neighboring wood at Seebach, in which nesting-houses had been 
systematically placed, the trees were uninjured. A similar effect was noticed in the orchards. At Seebach the trees always escaped the devastation of insects, while the neighboring orchards frequently suffered from their attacks. The inhabitants of the neighboring villages noticed this difference and began to hang up bird-houses, as a result of which a decrease in the caterpillar plague was noticed.

Those native birds which may be induced to live in artificial houses or around buildings are very valuable from the economic standpoint of the farmer. In tabular form below are given the essential facts regarding the food-habits of these birds, and also a table showing the frequency with which the young are fed. It is especially at this time, when the birds are feeding their young, that they are of great value on account of the enormous amount of food required by the nestlings. For the first days of their existence they eat more than their own weight of food in a day, and gain in weight from twenty to fifty per cent during the same period. The work of feeding begins at sunrise and continues without intermission until sunset, food being brought to the nestlings every four or five minutes. This consists almost entirely of insects, even for the young of the seed-eating birds. 
NEED AND VALUE OF ATTRACTING BIRDS 9

In the following table the figures indicate the per cent of total food.

\begin{tabular}{|c|c|c|c|c|c|c|}
\hline & \multicolumn{2}{|c|}{ Total Food } & \multicolumn{2}{|c|}{ To Birds' Credil } & \multicolumn{2}{|c|}{$\begin{array}{l}\text { To Birds' } \\
\text { Discredit }\end{array}$} \\
\hline & $\begin{array}{l}\text { Animal } \\
\text { Food }\end{array}$ & $\begin{array}{l}\text { Vegetable } \\
\text { Food }\end{array}$ & $\begin{array}{l}\text { Insect } \\
\text { Pesta }\end{array}$ & $\underset{\text { Peats }}{\text { Mammal }}$ & Grain & $\begin{array}{l}\text { Cuiti- } \\
\text { vated } \\
\text { Fruit }\end{array}$ \\
\hline $\begin{array}{l}\text { Bluebird } \\
\text { Chickadee }\end{array}$ & 76 & 24 & 53 & & 9 & \\
\hline (winter) & 77 & 23 & 28 & & & \\
\hline Flicker & 59 & 41 & 43 & & & 1 \\
\hline $\begin{array}{l}\text { Sereech Owl } \\
\text { Phobe }\end{array}$ & & & & 75 & & \\
\hline $\begin{array}{l}\text { Phoebe } \\
\text { Robin }\end{array}$ & 93 & 7 & 75 & & & \\
\hline $\begin{array}{l}\text { Robin } \\
\text { House Wren }\end{array}$ & $\begin{array}{l}42 \\
98\end{array}$ & 58 & $\begin{array}{l}35 \\
52\end{array}$ & & & 4 \\
\hline $\left.\begin{array}{c}\text { Martin and } \\
\text { Swallows }\end{array}\right\}$ & $\begin{array}{r}\text { Al } \\
\text { among }\end{array}$ & $\begin{array}{l}\text { are almo } \\
\text { the most }\end{array}$ & $\begin{array}{l}\text { st ent } \\
\text { valuab }\end{array}$ & $\begin{array}{l}\text { ely insec } \\
\text { birds to }\end{array}$ & & mer. \\
\hline
\end{tabular}

TABLE OF THE FEEDING OF NESTLINGS

\begin{tabular}{|c|c|c|c|}
\hline $\begin{array}{l}\text { Times } \\
\text { fed in } \\
\text { hour. }\end{array}$ & $\begin{array}{l}\text { Times } \\
\text { between } \\
\text { meals. }\end{array}$ & $\begin{array}{l}\text { Age of } \\
\text { Nestlings. }\end{array}$ & $\begin{array}{c}\text { Number } \\
\text { of } \\
\text { Young. }\end{array}$ \\
\hline
\end{tabular}

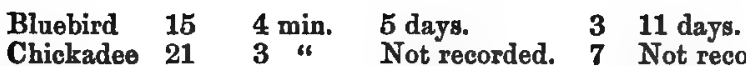

Martin 13 4-5 " Not recorded. 4 24-28 days.

Phobe $\quad 17$ 3-4 " 4 days. $\quad 2 \quad 15$ days.

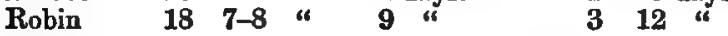

Tree

House

Swallow $14 \quad 4$ " 13 " $\quad 6 \quad 15$ "

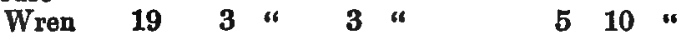

\section{Value of Winter Birds}

Not only in spring and summer may the birds be of great value to the farmer, but during the winter as well; so that efforts should be made during this season to attract birds around the 
orchard, that they may feed upon the eggs of the insects during the winter, and remain in the spring to attack the larvæ that may hatch from the uneaten eggs.

A very instructive experiment was tried by Mr. Forbush in Massachusetts. An old neglected orchard was selected, and during the winter months special effort was made to attract the birds by means of suet and other food. By this means chickadees, nuthatches, woodpeckers, and creepers were attracted to the orchard, remaining during the winter months. Observations of the feeding-habits and examination of the stomachcontents of a few chickadees showed that they were eating large numbers of eggs of the fall canker-worm moth, and the larvæ and pupæ of other injurious insects. In the spring, when the female canker-worm moths appeared in the orchard, the chickadee fed on these. While the trees in the neighboring orchards were badly infested with the worms, comparatively few were found in the orchard which had been frequented by the winter birds, and the few which did appear were easily disposed of by the summer birds which came to the locality. The trees in other orchards were almost stripped of their foliage, while this one retained its leaves, and with one exception was the only orchard in the neighbor- 
hood to produce any fruit. It should be noted that the exception was the nearest orchard to the one on which the experiment was tried.

Mr. Mann, a pear-grower of Rochester, New York, reports that one year the tree psylla had destroyed his entire crop, and that he thought there were no prospects of a crop the following year; but nuthatches came and worked in flocks in his orchard all winter, and in the spring he could find hardly an insect. Thus these nuthatches saved him thousands of dollars in one winter.

Such facts as these are worthy of the careful consideration of every fruit-grower and farmer.

\section{Problems of Bird Life}

The chief problems in the bird's life have to do with the securing of food and water, the rearing of the young, and protection at all times from the dangers to which they are exposed. Effective means of attracting birds must take all these problems into account. The food-requirement may be partly met by feeding birds in winter and planting shrubs and trees which provide fruit. The demand for water may be met by providing fountains which may serve for bathing as well as drinking purposes. The problem of rearing young may be solved by furnishing nest- 
ing-houses, nesting-material, and by planting shrubs and trees which provide nesting-sites. The question of protecting the birds may be partly met by furnishing shelter in the winter, and must always be taken into account in using the means mentioned above to attract birds around our homes, to see that they are not unduly exposed to such dangers as are found around human habitations.

In the following pages of this book the various means of meeting these demands of bird life are discussed under the following headings: nesting-houses and nesting-material; feeding winter birds ; drinking- and bathing-fountains ; shrubs, trees, and other plants to attract birds. 


\section{CHAPTER II}

\section{NESTING-HOUSES}

Adaptability of Birds. - Many birds have adapted their nesting-habits, in part, at least, to the changed conditions brought about through man's agency, where the changes have not been of too radical a nature. And some, indeed, seem to prefer these new conditions to the original ones ; chimney swifts have changed their nestingsites from caves and hollow trees to chimneys; the phobe rather prefers the beams of a shed or bridge to the cliffs, caves, and overhanging banks which probably formed its original nesting-site; the eave swallow nests under eaves as well as on cliffs; the barn swallow now nests almost entirely in barns, in preference to cliffs and caves, where it was once wont to nest; the robin frequently selects some portion of a building; the Carolina wren has been found nesting in a barn; several species quite commonly nest in artificial houses provided for them.

When the birds have shown such powers of adaptability without much effort on man's part to assist, there certainly is a large opportunity still 
further to draw birds around habitations, when man makes some special effort to attract them. It is the purpose of this book to render some suggestions looking toward this end. Not only may we hope to increase the number of individuals of those birds now known to nest around buildings and in bird-houses, but we may expect to domesticate other species of birds, whose nesting-habits are such that we may imitate their nesting-sites by means of artificial houses.

The birds which have been known to nest in bird-houses, as far as the author has been able to secure any records, are the following :-

\section{BIRDS USING NESTING-HOUSES}

(Those marked with an asterisk use houses quite commonly). Bluebirds :

*Eastern (Sialia sialis).

*Western (Sialia mexicana occidentalis).

Mountain (Sialia arctica).

Chickadees :

*Black-capped (Penthestes atricapillus).

*Oregon (Penthestes atricapillus occidentalis).

Carolina (Penthestes carolinensis).

Duek, Wood (Aix sponsa).

*Finch, House (Carpodacus mexicana frontalis).

Flicker (Colaptes auratus luteus).

Flycatcher, Crested (Myiarchus crinitus).

Hawk, Sparrow (Falco sparverius\}.

*Martin, Purple (Progne subis).

Owl, Screech (Otus asio).

Robin (Planesticus migratorius).

*Sparrow, English (Passer domesticus). 


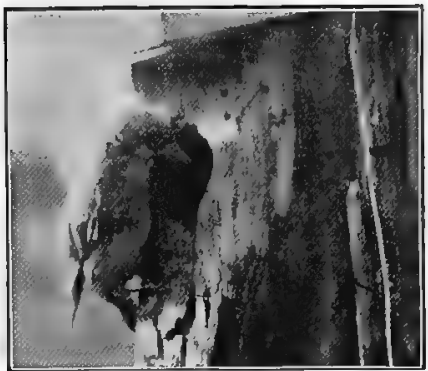

BLUEBIRD AT ENTRANCE TO NESTING-BOX

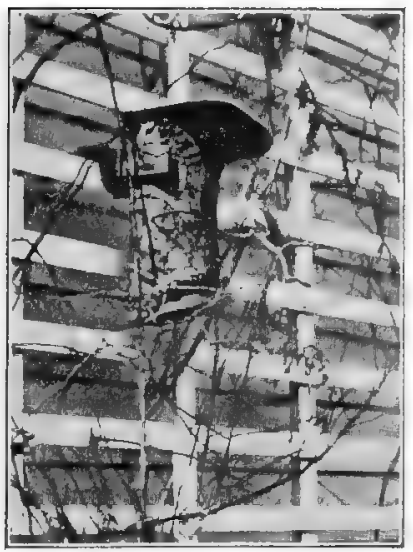

TREE SWALLOW AT NESTING-BOX

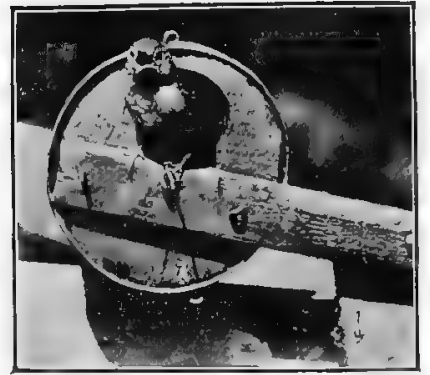

HOUSE WREN AND TOMATO-CAN HOUSE

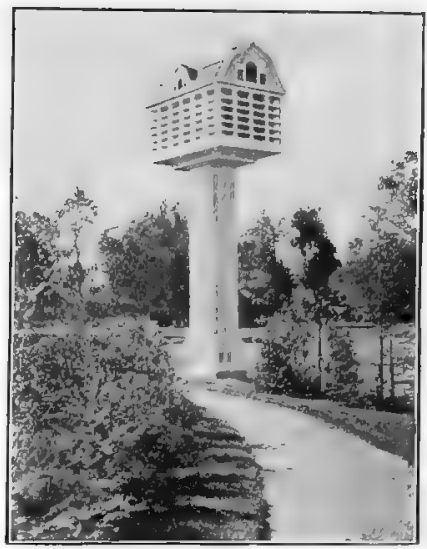

MARTIN-HOUSE

accommodating five thousand birds 

Starling (Sturnus vulgaris).

Swallows :

*Tree (Iridoprocne bicolor).

*Violet-green (Tachycineta thalassina lepida).

Titmouse, Tufted (Bceolophus bicolor).

Woodpecker, Red-headed (Melanerpes erythrocephalus).

Wrens :

*House (Troglodytes aëdon).

* Parkman's (T'roglodytes aëdon parkmanii).

Bewick's (Thryomanes bewickii).

*Vigors's (Thryomanes bewickii spilurus).

Texas Bewick's (Thryomanes bewickii cryptus).

The following nest in hollow trees and so might possibly be induced to occupy nestinghouses :

The woodpeckers, nuthatches, Carolina wren, barn owl, barred owl, and saw-whet owl.

There are other birds which may be attracted around buildings by putting up shelves or open boxes, or leaving openings in the barns; such as the phœbe, robin, barn swallow, eave swallow, chimney swift, and Say's phœebe.

In building a bird-house one must take into account the species for which the house is intended; but the author will first take up the discussion of a few general considerations before treating the question of special adaptations for each bird.

Hollow Limbs. - We may evidently hope to be most successful with that kind of house which 
most closely imitates the natural nesting-site of the birds. Those birds which have been induced to nest in artificial houses are of species which naturally select a hollow tree or limb in which to locate their nest. Sections of such hollow trees or limbs make some of the very

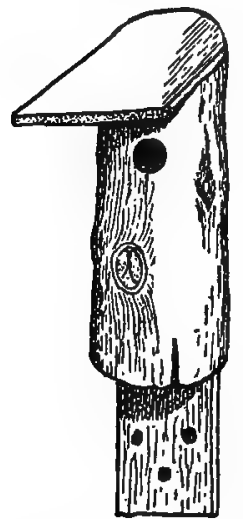

HOLLOW LIMB BOX best bird-houses. Sometimes pieces may be found with the centre already decayed, in which case it is necessary only to saw off a section of the desired length, fasten on a floor and roof, and make the entrance hole. It is desirable that the roof be put on in such a way as to be readily removed. To hollow out a solid limb, saw it in halves from one end to about three inches from the other, where a cross-cut is made at right angles. The two pieces may be gouged out to the desired size and wired or screwed together, so that they can be easily taken apart if desired. Or, if one has a large auger, a hole may be bored. If one happens to have a section of the wooden tubing of an old-fashioned pump, this may be made to serve as a substitute for a hollow limb.

Bark Houses. - Very attractive houses can 
be made entirely of bark. Limbs of trees, or small trees of the desired size, should be cut into sections of ten or twelve inches in length, about the latter part of June, when the bark can be easily removed. Elm, chestnut, or birch is especially recommended, and limbs which are free from knots should be chosen. About two or three inches from one end bore an entrance hole of the desired size through the bark. On the opposite side of the section make an incision lengthwise through the entire bark. By means of a wooden wedge carefully remove the bark. Saw off sec-

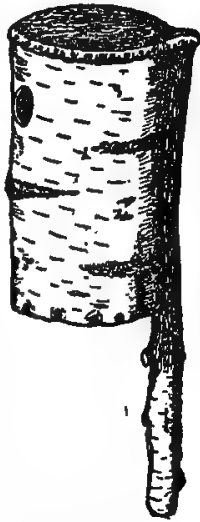

BIRCH-BARK HOUSE tions of the wood about an inch thick for the top and bottom. Trim these off a little, so that when the bark is placed around them the edges overlap about a half-inch. Nail the bark to these sections, and along the slit at the back attach a strip of wood which may be used to fasten up the box in the desired locality. To make the roof waterproof a piece of tin or zinc may be fastened over the top. In order that the box may be opened for cleaning or examination, in place of the section of wood the bark may be fastened to a hoop and the box covered by means of a cap of 
wood or tin fitting on over the top like the cover of a pail.

Very good imitations of tree-trunks may be secured by constructing boxes out of slabs with the bark on, or pieces of bark may be fastened on boards.

Board Houses. - It is not necessary, however, to use old limbs or bark to build a house which the birds will use. A satisfactory box can be made out of ordinary boards, the older the better, as the birds are apt to be frightened away by

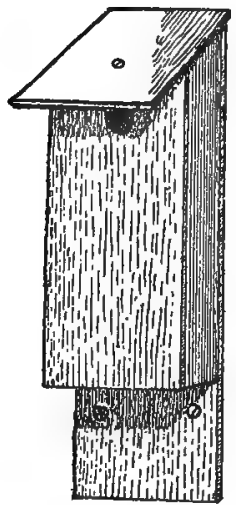

BLUEBIRD BOX new boards; but if these are used they should be smeared with moist soil and exposed to the weather as long as possible before the birds are expected to use the house, or they may be stained green or brown. In the construction of these houses a few points are to be noted. (1) The box should be very deep, that is, with the large dimension vertical; (2) the hole should be well up near the top, within two or three inches, with no perch near; (3) the roof should slope from the back toward the front and project out about three inches. The first two points make it 
difficult for the young birds to leave the house, with the result that when they do leave they are strong and better able to care for themselves than they would be had they left the house earlier. The combination of the three serves a twofold purpose: it prevents the rain from beating in and keeps the cats out. This is practically a cat-proof house. From whichever position the cat may attempt to reach the hole, whether from above or below, the projecting roof renders it extremely difficult for the animal to gain a position from which it can reach into the nest. The difficulty of reaching the house may be still further increased by attaching the house to a long slender support. The roof should be attached by hinges or in some other method so that it may be easily lifted. On the whole the author considers this the best type of house for bluebirds and chickadees that he has ever used. A projecting roof can be easily placed on the hollow limbs previously described, and the author also advises that a roof of this kind be put on the bark houses, if any danger from cats is anticipated.

Observation Box. - An observation box constructed like that shown here allows a splendid opportunity for studying intimately the home life of the birds. One side is attached by a hinge 
so that it can be opened, and inside is fastened a pane of glass. By this means the door can be opened by any one who wishes and a close

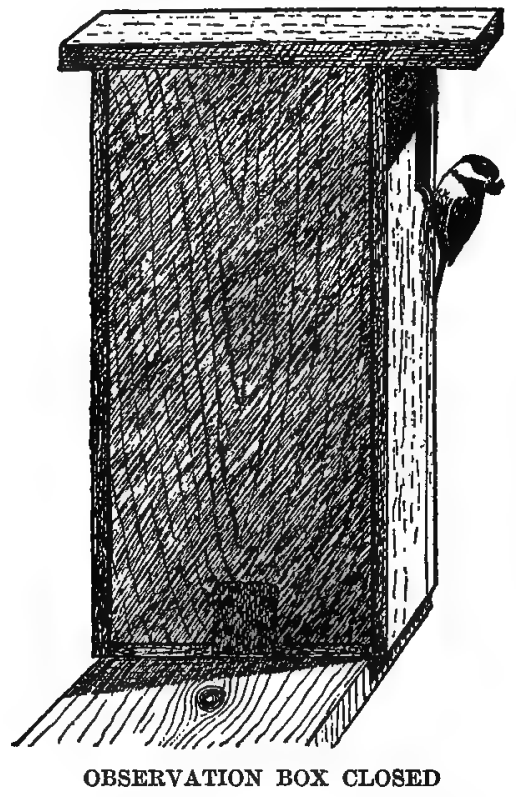

observation made of what passes inside; but the door should be kept closed at all other times to protect the young birds from the sun's heat. It should be so situated that the sun cannot shine in when the door is open. 
Tin Houses. - Quite a variety of houses may be made from various kinds of tin receptacles, such as tomato-cans, varnish-cans, coffee-cans,

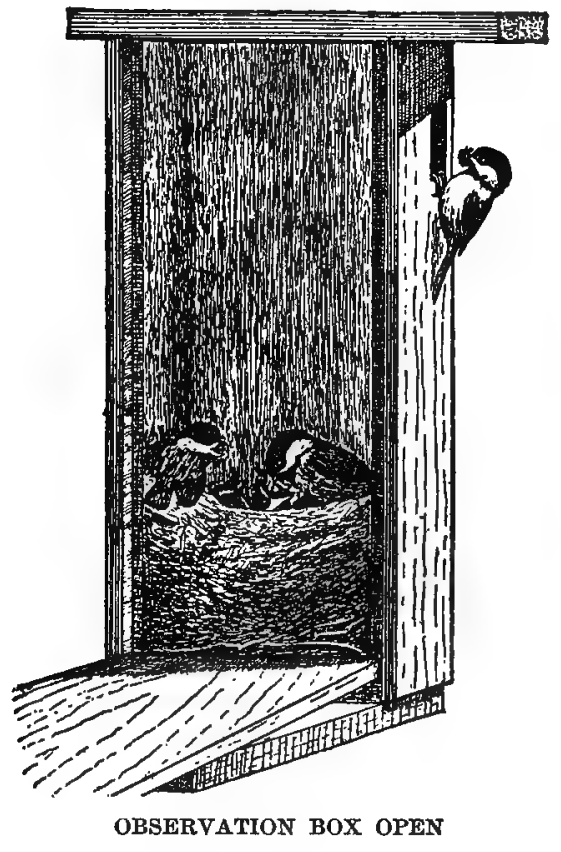

etc., by fitting in at one end a circular piece of wood, containing the entrance hole. It is well to place tin receptacles where they will be somewhat shaded, to prevent disaster to the young birds from the excessive heating of the metal. 
Gourds. - It is worth while to buy a package of gourd-vine seeds and plant them where they may be utilized to screen some unsightly objects; and when the gourds are matured they may be hollowed out and put out for nesting-houses, which may often attract the wren and perhaps some others.

Clay Houses. - In the School of Education of Chicago University the children modeled birdhouses from clay. These were baked a brownish color, and made with concave backs to fit the trees, to which they were fastened by means of wire. One house was provided with a movable concave cover to catch the rain. The overflow from this led to a little cup on the outside, and this in turn connected with a cup on the inside which kept the birds provided with drinking-water.

There should be only one compartment and one entrance hole for all birds, except the martins, which are the only ones to nest in colonies. If two compartments are made, they will seldom, if ever, both be occupied; and they lead to fights, and furnish an additional opportunity for the sparrow to become troublesome.

Ventilation. - In addition to the entrance hole, there should also be some openings to allow 

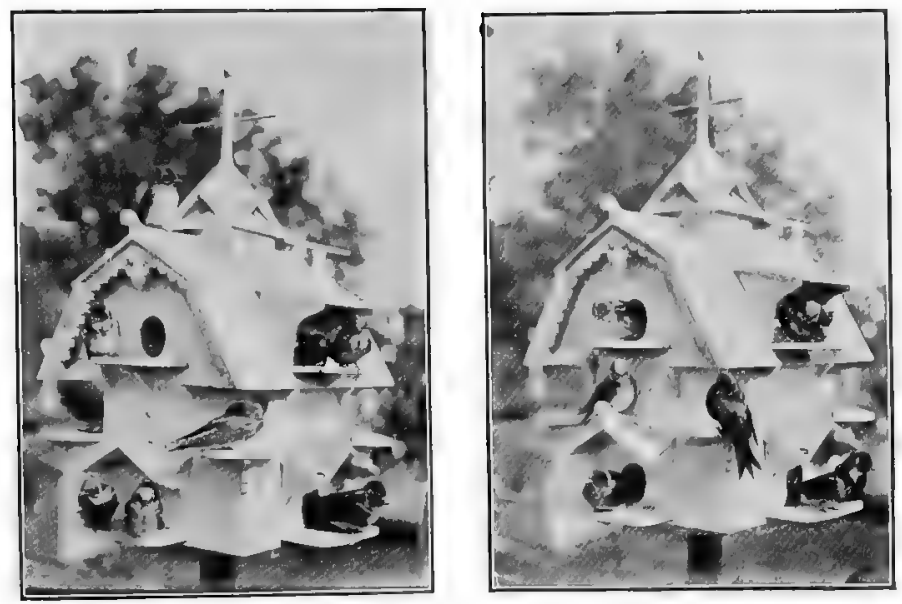

TWO VIEWS OF A MARTIN COLONY

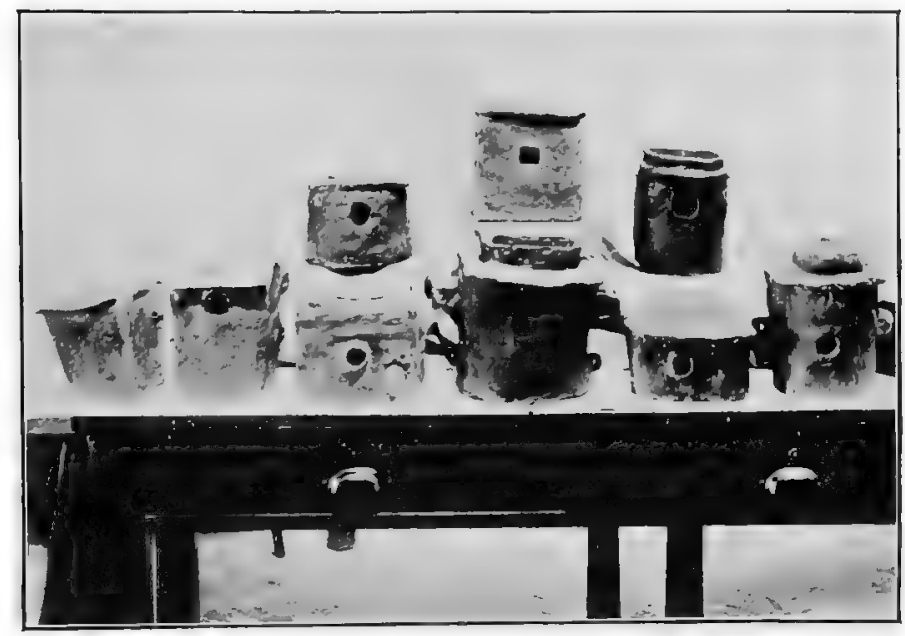

CLAY BIRD-HOCSES 
ventilation. During the heat of the day, especially if the boxes are not in the shade, the air inside becomes very hot and impure, and doubtless the young must suffer considerably unless arrangements are made for a change of air.

In constructing the houses of boards, a narrow slit may be left on each side under the roof. A series of small holes may be bored in the upper part of the hollow limbs or bark houses; nailholes may be made in the tin receptacles.

Drainage Holes. - It is also well to bore a few small holes somewhere in the bottom of the boxes to allow any water to drain out that may beat into the boxes during storms ; and, of course, there should be no openings left on top by which the water can enter.

Movable Covers. - It is very convenient to have some arrangement by which the houses can be opened for examination if desired. This will allow opportunity for removing the eggs of the English sparrow, and for cleaning out the box at the end of the season. This may be arranged in several ways. The author has

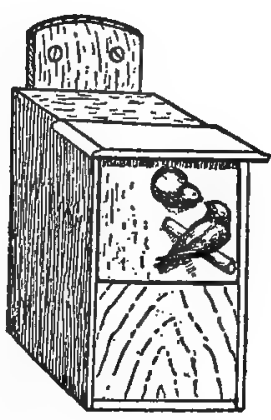

BOX WITH SLIDLYG COVER 
found it very convenient to attach the roof by means of hinges at the back and a little wire clasp on the side in front.

Time to put out. - The earlier the boxes are put out, the better. For some weeks before the birds seem to be ready to begin nesting, they are undoubtedly flying around searching for a site, and these houses, if placed early, may induce some birds to stay, of whose presence we might not otherwise have had even the least intimation. It is also well to have the houses out early so that they may become weather-beaten. Some birds rear two broods, in which case a house may be occupied which is not put out until late in the season; but it is much better to have the houses out by the time the birds are beginning to return. The boxes may also be put out in the late fall, so that they may serve as a shelter for the winter birds. The different houses should not be placed too close together, as the first-comer is apt to prevent the other birds from nesting in the houses near.

In case one has an orchard near at hand, this makes an ideal location for placing the boxes. In the yard the boxes may be fastened to trees, posts, grape-arbors, or even to the piazza-posts or side of the house. It will afford better protection 
from the elements if the box is put up with the entrance hole facing away from the direction from which the prevailing storms come, although with the kind of roof shown on page 18, this matter becomes of less importance.

Ernest Thompson Seton gives the following general suggestions: "As a general principle I find that the birds like a tight fit. Small birds will not nest in a large hole. I find it a good plan, in some cases an essential, to go around in the spring. and dust the nesting-houses with powdered sulphur. They become so infested with parasites that the birds cease to use them. In fact I believe it a good plan to clean out the old nests completely every year. As a practical detail, I have found it worth while to have each nest with a hinge door which would admit of easy inspection without disturbing the inside arrangements; and second, to place none so that they cannot be reached by a convenient ladder."

The chief things to be taken into account in adapting a house to a particular bird are, - size of house, size of entrance hole, location of the house, and the kind of house preferred. The second point is especially important, as the regulation of the size of the hole allows one to keep out all birds larger than the one for which the 
house is intended. A circular entrance hole is to be preferred.

Bluebirds. - The boxes should be about twelve by six by six inches, fastened with the longer axis vertical. If a hollow limb is used, a diameter of five inches, or a little less, will be sufficient. The entrance hole should be one and a half inches in diameter. The two-inch hole often recommended is too large, as martins and blue jays may enter this. Occasionally they will use a smaller hole, down to one and a quarter inches, but an inch and a half is the smallest hole to use to make sure that the houses will be occupied. Place from eight to fifteen feet high. They may be fastened to trees, posts, grapearbor, tops of poles, and buildings. Put out by the first of March or sooner.

In the Eastern States the bluebird is one of the most common house-tenants. Mr. Frank Bond writes that in Cheyenne, Wyoming, while the English sparrows were killed off, the mountain bluebird was among the most common bird-box occupants. In Oregon the western bluebird is a common tenant.

Chickadees. - The boxes should be about ten by four by four inches, placed with the long axis 
vertical. The entrance hole may be one and a quarter to one and an eighth inches. The smaller size would be more effective in keeping out the English sparrow. Place on a tree, post, or even on the house, by a window ; from ten to twenty-five feet high. These birds are permanent residents, and do not begin to nest until the middle of May, but Mr. Forbush, who has had considerable success with domesticating chickadees, recommends that the house be put out in the fall, so as to furnish the birds with shelter during the winter. These are among the easiest birds to attract during the winter by providing food, and if they remain during the cold season and use the box as a shelter, they will be more likely to stay and make their nest here. Mr. Forbush writes: "Success in domesticating the chickadee seems to turn mainly on four conditions : first, the locality must be well supplied with trees; second, the English sparrow must be banished from the neighborhood; third, the chickadees must be accustomed to remain about the locality by providing food for them in winter; fourth, the boxes must be properly constructed and located."

Sometimes the chickadees may be induced to build in partially decayed birch-stumps, by boring one and an eighth inch auger holes in the sheltered side. On finding these holes begun, the 
chickadee may finish the excavation and build a nest there. Mr. Reed states that one summer four pairs of chickadees found the locations selected by him satisfactory and reared their families.

In the Eastern States the black-capped chickadee nests occasionally in boxes, but is not a common occupant. On the Pacific coast the Oregon chickadee uses boxes, and from the reports received, apparently more commonly than the black-capped does in the East.

Carolina Chickadee. - The only reference the author finds to this bird is in "Bird-Lore," by Mr. Robert Ridgway of the National Museum, who writes: "Each spring a pair of Carolina chickadees build their nest in one of our birdhouses, and have begun incubation by the time the house wrens arrive, but that is as far as the poor chickadees ever get, for the wrens immediately oust them and destroy their eggs."

Wood Duck. - This beautiful bird is rapidly decreasing and seems in a fair way to extinction, unless some very unusual efforts are made in its behalf. It nests in a hole in a tree or stump, and has been known to nest in houses provided for it. Dr. A. K. Fisher, of the Bureau of Biological Survey, writes: "Almost any box or keg of 
proper size is a suitable nesting-place for the wood duck. A good, stout nail-keg with the head replaced, or a box a foot square and ten inches high, made of three-quarter-inch stuff, will be large enough. The oval entrance on the side should be six inches long by four inches wide. I know of a number of instances where wood ducks have nested in places pre. pared for them." Ernest Thompson Seton writes: "Wood ducks do not seem to desire being very near water. Wood ducks and whistlers like a drop of a foot or two from the entrance hole to the nest-level. They will not use a box in which they can be seen

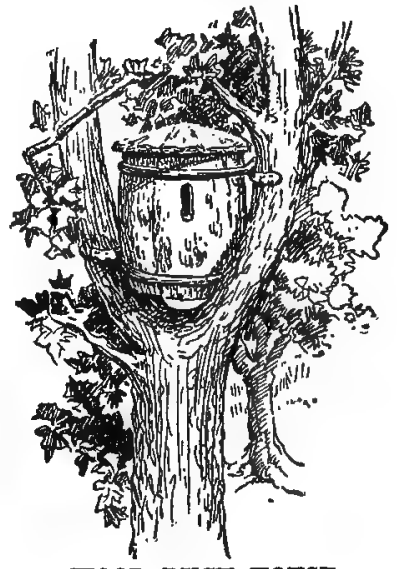

WOOD DUCK HOUSW while setting." The cut shows a box suggested by Dr. Fisher.

House Finch. - Mr. Frank Bond writes that when living in Cheyenne, Wyoming, the house finch was amongst the most common bird-box occupants, when the English sparrows were killed off. 
Dr. W. H. Bergtold of Denver writes that the house finch is very abundant in Colorado cities and villages, and takes advantage of any box, shelf, etc., about a house, to build its nest.

Flicker. - The author has been able to secure but two definite records of the flicker using a nesting-box. One is furnished by William Brewster, who writes: "In the spring of 1899 a pair of flickers lived in an imitation stub that I put up for them in the garden here. It was simply a long, narrow rectangular box, made of boards covered outwardly with spruce bark and having an entrance hole of suitable size (three and a half inches diameter) bored in one side near the upper end. Eight eggs were laid, but none of them hatched, although the birds brooded them for nearly six weeks. Last spring (1908) I put up a box of similar construction in an orchard at Concord, Mass. Although the flickers did not build in it, they must have frequented it more or less as a sleeping-place, for when I examined it this autumn, I found their feathers clinging to the wood about the entrance hole."

Under date of May 24, 1910, Mr. F. C. Pellett writes that a pair of flickers is occupying one of his houses, in which seven eggs have been laid. Instances have been reported in which flickers 
have enlarged the holes to bluebird boxes so that they could get in, but the boxes were too small to nest in.

In Burns's monograph on the flicker are given the following figures regarding the inside dimensions of flickers' nests, the data being gathered from various sections of the United States:-

$\begin{array}{lccc} & \text { Minimum. } & \text { Maximum. } & \text { Average. } \\ \text { Diameter of entrance } & 2.20 & 5.00 & 3.28 \\ \text { Diameter of cavity near bottom } & 4.50 & 10.00 & 7.67 \\ \text { Depth of cavity from entrance } & 6.00 & 36.00 & 15.79 \\ \text { Total length of cavity } & 9.00 & 40.00 & 18.50\end{array}$

The figures given in the average column will suggest the dimensions of a nesting-box for the flicker.

Crested Flycatcher. - The author has found five records of the nesting of the crested flycatcher in boxes. One pair nested in the hollow limb described on page 44 , after it had been left by the titmice. It was also used the following season by the flycatchers. In two other cases these birds nested in one of the compartments of a martin-house.

Mrs. G. K. Holmes, of Summit, New Jersey, reports a pair nesting in a box in the spring of 1908. "It was a little house of about six and one half by eight and one half inches, with an opening 
two and one eighth inches across, and was old enough and time-colored enough to please any bird visitors." It was placed in the crotch of a dead peach tree nine feet from the ground. It was about ten feet from the house and near a path in constant use. Two young birds were successfully reared.

Sparrow Hawk. - In the spring of 1910 a pair of sparrow hawks occupied one of Mr. Pellett's nesting-boxes, in which, at the time of the last report received by the author, five eggs had been laid.

Purple Martin. - The purple martin is common in the South, where gourds and boxes are put out for its use. In the North, however, it is rather rare and very local in its distribution, and has been decreasing for quite a number of years, partly on account of unfavorable seasons, but chiefly, it is probable, on account of the English sparrows. One of the chief causes for the disappearance of the martin from many localities, was the cold, wet June of 1903. The birds found it impossible to secure food for their young, so that many nestlings, as well as adults, perished. Before that year, however, the martin had been decreasing on account of the persecutions of the 
English sparrow. In the following spring many of the houses were visited by the martins, but few occupied. In some cases failure to reoccupy the houses may have been due to the fact that they had not been cleaned, but still contained the remains of the birds which had died the previous year. Several observers reported that the houses which had been cleaned were occupied by the martins, while those which had not been cleaned were not used. It seems to be a precaution worth noting to clean the houses each year before the migrants return.

As the result of extensive correspondence, Mr. Forbush could find authentic records of the breeding of the purple martin in only five localities in Massachusetts during the season of 1904. During the season of $1908 \mathrm{Mr}$. Horton was able to find records of only one colony breeding in the eastern part of Vermont, that at Lyndonville. For the same season, Mr. Forbush writes : "Martins are still very plentiful in Eastern Maine, where the bad weather of 1903-04 hardly made itself felt at all. Also there are a good many in Connecticut and Rhode Island, and quite a few in New Hampshire."

The martins are valuable birds from the economic standpoint, and it is well worth while to make efforts to induce them to return to the 
localities where they formerly nested. They have the habit of returning to the same houses, year after year, both old and young, till their numbers compel them to seek quarters elsewhere. Thus there is the best opportunity for establishing a new colony in the vicinity of other colonies, the overflow of which is compelled to seek elsewhere for a nesting-site.

Attempts to rëstablish Martins. - Various attempts have been made to establish new colonies at a long distance from breeding colonies. The general plan pursued is to raise young birds in the locality where it is desired to establish a colony, with the hope that in the following spring these birds will return to their new home and breed there.

In the spring of 1907 eggs were sent by J.W. Jacobs of Pennsylvania to W. C. Horton, Brattleboro, Vermont, where they were placed in the nest of a tree swallow which had taken possession of a deserted martin's house. The eggs hatched and the young were fed by the parent swallows for two weeks, at which time all the young were killed by some unknown cause. The following year (1908) two pairs of martins which had begun to nest were sent to the same locality, where they were placed in the house which had 
been arranged for them, but the birds deserted it immediately, and nothing more was seen of them till about six weeks later, when a single male, which may have been one of these, was seen in a neighboring town.

For several years eggs were sent to Charles H. Kingsbury, Barnard, New York, and placed in the nest of barn swallows. In nearly every instance the eggs hatched, but some accident befell the young birds. In 1907 six young birds were sent to the same locality and were raised by hand. Three of these were successfully raised and liberated. Mr. Kingsbury stated it was wonderful the number of insects these youngsters devoured; one of his farm-hands spent his entire time in attending to their wants.

In the spring of 1908 martins' eggs were sent by Mr. Jacobs to Mr. Daniel C. Robinson, Manchester, Maine, who placed them in the nest of a phobe. The bird continued to sit upon the eggs, but they had been injured so that they never hatched.

Mr. Robinson also tried another experiment the same season. A house full of martins, both old and young, was brought by night from a neighboring locality and set up on a pole in his yard. The old birds deserted the house, and so the young were fed by hand on grasshoppers, a mix- 
ture of bread-crumbs and hard-boiled eggs, and some prepared food for soft-billed birds, furnished by a bird-dealer. In this way a few birds were successfully reared.

The following account of another experiment along this line is taken from Circular No. 56 by H. W. Henshaw of the Bureau of Biological Survey:-

"In the Zoölogical Gardens of Philadelphia, in $1889, \mathrm{Mr}$. Robert D. Carson, by means of a trap-house, secured a colony of nine pairs with thirty-two young from the grounds of Mr. Josiah Hooper of West Chester, transporting them the distance of about twenty miles by train at night. When released next morning the old birds deserted the young and returned to West Chester. The temptation of the old home so close by proved too strong even for parental affection. Most of the young, however, were successfully raised by hand-feeding, being fed chiefly cockroaches, grasshoppers, crickets, meal-worms, and prepared food. This is a mixture intended for insectivorous birds, and according to Mr. Carson was well liked by the nestlings and agreed well with them. It consists of ground and dried beefheart, mawmeal, ground zwieback, boiled and mashed white potatoes, grated raw carrot, and grated hard-boiled eggs. Probably any similar 
mixture would answer equally well. A small colony resulted from this experiment, which would probably have proved permanent but for the fact that additional houses were put up in West Chester, and after two years the colony deserted the old neighborhood. Though only temporary success was achieved, the experiment is encouraging and points the way to ultimate success. For the above facts I am indebted to Mr. Charles J. Pennock of Kennett Square, Pennsylvania.

"As the young can be raised by hand without serious difficulty, it may be easier to start the new colony with nestlings alone, feeding them on meal-worms, grasshoppers, and the like. Six or eight pairs can well be spared from a strong colony without unduly weakening it. This method promises well, and if the experiment can be tried from year to year, even on a small scale, a gradual increase in the number of martin colonies is likely to result and new centres of distributions to be formed."

Martin-houses. - The martins prefer to nest in colonies, so that houses should be provided which contain a number of compartments. Each dimension of a single room should be about six or seven inches. The entrance hole may be either square or circular, and should be about two and 
a half inches across. The best height for erecting the house is from fifteen to twenty feet, although houses placed much higher may be used, cases being recorded in which houses placed as high as fifty feet were occupied. To prevent the English sparrow from getting established early in the season, it is well to keep the holes covered till the return of the martins, or to arrange the house so that it can be taken down in the fall and put up again in the spring.

Barrel House. - The following suggestions for making a martin-house are taken from Edward H. Forbush's "Useful Birds and Their Protection":-

"A house for a large martin colony ordinarily involves the expenditure of a considerable sum; but a very good house, that will accommodate a colony of ordinary size, may be made from a flour barrel. The roof is of zinc, or of wood covered. with painted canvas. The martin-house should be placed on a pole at least fifteen to twenty feet high. It should have several large rooms, with entrances two to three inches in diameter, that it may provide room enough for several pairs of birds, and that each tenement may be readily inspected and cleaned when necessary, and the whole house should be painted in light colors, 
that the young birds may not suffer too much from the rays of the hot sun. It should be so constructed that the young birds may not be readily crowded out of the nest, and so become the prey of cats. Such a catastrophe may be guarded against by having a shelf or piazza extending round the house beneath each tier of doorways, and constructing a railing at least three inches high around the platform. Each of these platforms should have a slight downward pitch, to carry off the rain and prevent it from driving into the doorways below. There should be no brackets beneath the box, for they afford the cat a foothold. Many other designs will suggest

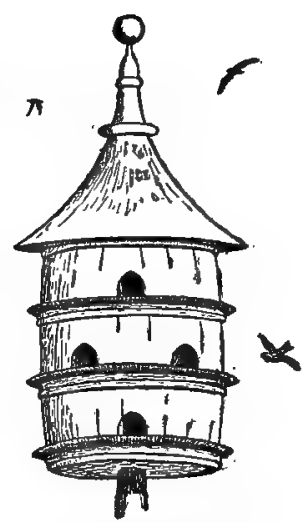

BARREL HOUSE FOR MARTINS

(Designed by E. H. Forbush) themselves. A barrel might be covered and roofed with bark and the railings made of twigs. In fitting up the rooms, a square box should first be made to go up the centre of the barrel. All the rooms will be backed by this, and the pole will go into it. Rooms may be fitted into the barrel by merely fastening cigar or other boxes back of each hole. The pole may be made 
to go into a socket in the ground, and then both pole and house may be taken down in the fall and kept under shelter until the martins return in the spring; or, if the pole is hinged near the bottom, the box may be still more readily taken indoors. This will prevent the sparrows from intrenching themselves within. If a cedar pole is used, the bottom should be well tarred wherever it comes in contact with the ground. It should be set deep in the ground to give it the requisite firmness. If the nests of martins are dusted occasionally with fresh insect powder, it will relieve them of the vermin which always congregate in large occupied bird-houses."

Screech Owl. - Only one record has come to the author's notice of the nesting of the screech owl in artificial boxes, - that by Mr. E. H. Forbush, in "Useful Birds and Their Protection." "A box of 12 inches square and 15 inches high is probably none too large for the screech owl, as three or four young birds soon render the nest very filthy, and on this account require extra room. Nevertheless a pair of screech owls, at our home in Wareham, reared a brood of four young in the grocery box shown in the illustration. Allowing the birds to be the best judges of what they want, the dimensions of this box, seven by 


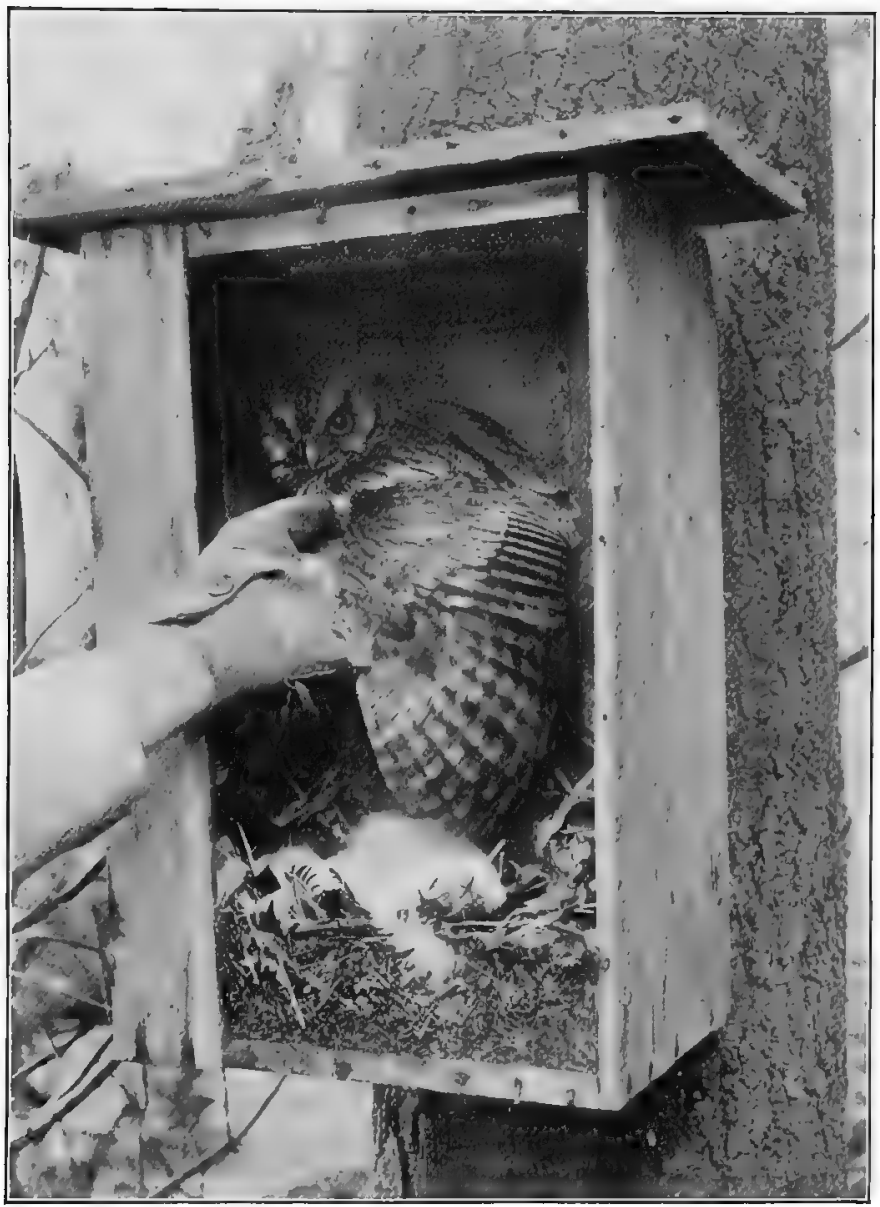

MR, FORBUSH'S SCREECH OWL IN NESTING-BOX 
eleven by fifteen inches, and size of entrance hole, three by four, may be useful to those who wish to attract this bird."

The following very interesting note concerning the value of this bird in keeping in check the English sparrow, comes from Pennsylvania: "In West Chester, a town of 11,000 people, there are dozens of little red and gray screech owls hiding in the old dead trees in the daytime and at night sallying forth to make a meal on the English sparrow. They are making their mark, too, for the sparrows are becoming less abundant to a considerable extent, and the people have come to a realization of the good the owls do, and are giving them protection."

Robin. - In the fall of 1907 the author gathered statistics from the school children of Passaic, N.J., relative to their experiences with bird boxes during the spring and summer, special effort having been made during the previous winter to interest the children in birds and the construction of bird houses. Five cases were reported in which the robins began to nest in these houses and one in which they successfully reared their young. The author took special pains to investigate these cases as thoroughly as could be done in the fall, and was convinced that in two 
instances the reports were correct, one being the case in which the young had been successfully reared. Medium-sized soap-boxes had been used, with holes three or four inches in diameter. While the natural nesting-sites of the robin would not suggest that it might select such a closed box, yet the friendly way in which it has domiciled itself in all sorts of locations around buildings renders the above instances not at all improbable. Undoubtedly, however, the robin will be attracted more by platforms and open boxes as suggested further on in the chapter.

Starling. - Several instances have come to the author's notice where the starling has nested in houses and kegs. There is little doubt that these birds can be induced to nest in houses if we wish to have them. As yet, however, the bird is of so comparatively limited a range, and its habits are so little known, that we do not yet know whether it is to prove a beneficial species, whose presence is to be encouraged, or another nuisance like the English sparrow, only a larger one. The reports from different observers so far are conflicting; but judging from the majority of reports received and from the fact that it seeks hollow trees and other cavities for its nesting-site, it 
seems probable that as it increases it will help drive away some of our more valuable native birds and become eventually a pest like the English sparrow. On the whole, probably it is not worth while to make any attempts to attract this bird to our nesting-houses, for the present, at least, till more is known about its habits and value.

Tree Swallows.-The tree swallow is a not uncommon house-tenant in some sections of the East. The boxes should be about twelve by six by six inches, fastened with the longer axis vertical. The entrance hole should be one and one half inches in diameter. The boxes may be fastened to trees, poles, or buildings. Place from eight to twenty feet high. They should be put out just as soon as the birds return in the spring. In some instances these birds have been reported as nesting in martin-houses which had not been occupied by the martins.

Violet-green Swallow. - This is one of the commonest house-tenants in Oregon. Supt. L. R. Alderman of Eugene, Oregon, writes: "We have found that the violet-green swallow is eager to inhabit any house that is out of the reach of cats, and is firmly attached to any building, if it is 
placed on the east or north side. We have had the best luck, however, with a house made from a round trunk of a tree. Take a trunk, say 8 inches through and 12 inches long; saw off from one end a piece 2 inches long, with brace and bit dig out an opening 8 inches long and 6 inches wide. Then nail on the end sawed off. Make a suitable ventilation at top; bore entrance 1 inch in size near upper end of cavity. Make perch of twigs." Dr. E. J. Welty of Portland, Oregon, writes: "The violet-green is very partial to boxes; he likes his nailed up in a safe place on the side of the house or under the eaves."

Tufted Titmouse. - The author has found but one record of this bird nesting in a house; this record is given by Mr. Earnest Seeman, of North Carolina, in "Bird-Lore": -

"A hollow section of dogwood, over a yard in length, and with an inside diameter of 5 inches, was strapped to the trunk of an orchard tree. The lower end was simply plugged with a few old chips and sticks, while a small board tacked over the top served to keep out the rain and sun. An irregular opening was cut inside the log, measuring about four by two and a half inches. A pair of tufted titmice were the first occupants. They reared a family of five." 
Red-headed Woodpecker.-Mr. F. C. Pellett of Iowa reports that a pair of red-headed woodpeckers occupied a house which he had set up. The box was made of an old rabbit-trap and placed about fifteen feet high in the edge of a grove. This was first occupied by a pair of bluebirds, but these were driven out by a pair of redheads after they had enlarged the hole so they could enter. They remained about the house all summer; but Mr. Pellett saw no indications of young birds, and not wishing to disturb the birds, he did not attempt to look into the box.

House Wren.-The boxes should be about seven by five by five inches, placed with the long axis horizontal. This position is preferable on account of the habit the birds have of filling the fore part of the house full to the hole with sticks, and leaving a hollow in the rear for the eggs and young. These little houses may be made quite ornamental by putting on a roof and staining the whole house green or brown. The entrance hole should be one inch in diameter, placed in the upper half. The size of the hole is important, as this size keeps out the English sparrow. The wrens like to nest very near the ground - from six to eight feet. Put out by the middle of April or earlier. 
The author has been very successful with house wrens by using an old tomato-can. An empty can was placed upon a hot stove, with the cut end down, till the solder melted, and then the rest of the cover was knocked off with a poker. A circular piece of wood from a half-inch board was cut out so as to fit into the can. A one-inch hole was bored into the circle a little above the centre, and then the board was fastened in place by driving tacks through the tin. Nails were driven obliquely through the rear of the can into a strip of wood, by means of which the house was fastened in the desired position; or the can may be suspended by means of wire placed around it. In one can of this sort, made by the author, there were successfully reared, in four successive seasons, five broods of house wrens, making a total of from twenty-five to thirty young birds. The wrens seem to be not at all particular as to what they use, as long as there is a hole by which to enter and a place for building the nest. A large funnel may be fastened up to a board.

The house wren is one of the common housetenants, and owing to the fact that it can enter a smaller hole than the English sparrow, there is a better opportunity of protecting it from the persecutions of this pest than there is of protecting 
some of our larger birds, such as the bluebird, the swallow, and the martin.

Parkman's Wren. - On the Western coast the place of the house wren is taken by Parkman's wren, which is a common bird-house occupant. Dr. Welty writes that these wrens require an entrance hole quite large enough for the English sparrow to enter easily.

Vigors's Wren. - Vigors's wren also nests in bird-houses in Oregon, but is smaller than the preceding species, so that the hole may be made small enough to keep out the sparrows.

Bewick's Wren. - Two observers have furnished data regarding this bird. Mr. O. Widmann of St. Louis writes : "Bewick's wrens have made nests and laid eggs in my boxes at Old Orchard, Mo. (a suburb of St. Louis), in two years, both broods being unsuccessful. As the Bewick's wren comes to us about the middle of March, a month earlier than the house wren, it had already laid eggs when the latter appeared on the scene and wanted possession of the box. There was some quarreling going on for a few days, after which the Bewicks left the place entirely."

Mr. W. G. Savage, of Monteer, Mo., writes: 
"The Bewick's wrens will place their nest in many kinds of places, and it is very easy to get them to breed near the house, or if they can get in, they will build in the house. Quart tin cans tacked up in some out-building where they can get in are very agreeable to them, and they will place their nest therein and be perfectly at home. I have one in my barn where they rear two broods each year when not molested. They will use any kind of a bird-house placed in almost any location, excepting too high up. They are very easily suited, and all they need is a little protection."

Mr.Harry C.Oberholser writes that in the West the Texas Bewick's wren readily adopts artificial houses.

The author has been able to find no other records of birds using artificial houses than those previously discussed, buta few general suggestions are given for houses to attract some other birds, which it would seem might eventually be induced to occupy them.

Woodpeckers. - The author has not been able to find any records in this country of nestinghouses being occupied by woodpeckers, excepting the flicker and the red-headed woodpecker, although these are the birds par excellence of hol- 
low excavations. In looking over a German publication on methods of attracting birds, the author finds that woodpeckers are very common occupants of artificial nesting-houses in Germany, and a description of the houses used there may give the clue which will lead to success in this country.

Experiments in Germany. - Baron von Berlepsch in Germany has made a life-study of woodpeckers' nests, collecting hundreds of them, and he finds that they all agree in certain features, namely : the opening is always circular and of unvarying size for each species; the entrance holes all incline upwards at a certain angle, to prevent the rain from coming in ; the lower portion of the nesting-cavity is enlarged in a gourd shape, and ends in a pointed trough at the bottom; the inner walls are roughened somewhat to allow the birds to cling to them more easily; and in the extreme point of the nest are a few fine shavings.

Baron von Berlepsch has constructed a nestinghouse embodying all these features. The results following the use of this house are very remarkable. Of five thousand boxes hung up by Baron von Berlepsch in his own woods, and of about ten thousand hung up in other localities by state authorities, ninety per cent or over were occupied. 
And this was true in some localities where unsuccessful experiments had been tried, in previous years, with other kinds of nesting-houses. These houses are being made and sold in large quantities by a German manufacturer, and in one case are being made and used on a large scale by German state authorities.

Maurice Thompson is authority for the statement that all of our woodpeckers, except the ivory-billed, construct their nests in the form of a gourd or gradually widening pocket. This is similar to the shape of the nests of European woodpeckers as found by Baron von Berlepsch. The houses constructed in this country have usually been made with flat bottoms, and so have been occupied by birds which construct a nest, and have not been adapted to the use of woodpeckers, which make no nest and have the bottom of the cavity so formed that the eggs will be kept together. So many birds use deserted woodpeckers' holes, that it may be worth while to construct our houses of this shape even when they are intended for other birds than woodpeckers. This shape of nesting-site is especially adapted for the flickers, which usually incubate by squatting on their eggs in an upright position. Perhaps other woodpeckers may have the same habit. One correspondent suggests that cement 
or mortar may be modeled in the shape of the nest and placed on the floor of the house.

Houses made after the model of those used in Germany would certainly give much promise of success. They should be made of sections of limbs or small tree-trunks. These may be easily split and the inside hollowed out in the proper shape, and then the pieces fastened together again. The size of the cavity and the entrance hole must depend upon the species for which the box is intended, the hole varying from an inch and a quarter for the downy to three and a quarter inches for the flicker. The largest internal diameter of the cavity just before it begins to taper toward the bottom should be from two and a half to three times the diameter of the entrance hole.

To furnish the slight amount of material found in the woodpecker's nest for the eggs to rest on, there may be placed in the bottom a little of a mixture of earth and sawdust, the amount depending on the size of the box. To prevent rain from beating into the box, it should be fastened vertically, or with the upper end leaning in the direction of the opening, and the opening should face away from the direction of the prevailing storms.

Nuthatches. - The nuthatches become so tame during the winter while seeking food that may be 
placed out for them, that it would seem that they might be induced to remain and nest. In order to make the house as attractive as possible, one will probably stand a better chance of success if hollow limbs or bark houses are used, a foot or more in length and five to six inches in diameter, with an entrance hole of about one and a half inches for the white-breasted and one inch for the red-breasted. To find the most attractive location, the house may be attached to a tree in an orchard or woods. The best way to attract these birds, and also woodpeckers, is to leave standing old trees which have hollows in them suitable for nesting-sites. Mr. Forbush writes that a pair of mated red-breasts at his house were looking for a nest in the house, and the female crept into a partly raised window upstairs and fluttered herself to death.

Carolina Wren. - The author has not been able to find any record of this bird using a nesting-box, but from the nature of the localities which it selects for its nesting-sites there seems little doubt that it might easily be induced to do so. Following are the locations in which it has been reported as nesting: in a broken gourd thrown on an arbor of a grape-vine ; in a wash-basin left on a mantel of an abandoned negro cabin; 
among boards in the garret of a barn; in an old cap hanging on a nail inside of the lattice-work of an outhouse; under roofs of porches of occupied houses; on a pantry shelf adjoining a kitchen, the pantry being visited many times daily; behind a bookcase in a study.

\section{Birds around Buildings}

In addition to those birds which nest in closed houses, there are some others for which inducements may be held out to nest around buildings.

Robins. - For robins shallow trays may be placed in suitable locations. Mrs. M. O. Wright, in " Bird-Lore," writes: "Three years ago I tried the experiment of having some flat, shallow trays about six inches square, bracketed in suitable locations so as to form attractive nesting-places for nest-building robins, who, as we all know, are fond of straddling a tree-crotch with their compound of clay and grass or utilizing any flat beam or odd nook that will go for a nesting-place. These boxes had a few holes in the bottom so that they should not hold water, and were placed so that a branch or other protection afforded at least partial top shelter. The first season the robins examined but distrusted the contrivance; 
the second, two were used; while last year five were occupied by robins and the sixth was appropriated by a phobe, who has thus kindly given me a hint for more trays to be placed in locations likely to suit this lovable worker for garden good."

Phobe. - The phœbe prefers some covering above its nest, and for this bird, shelves or open boxes may be nailed

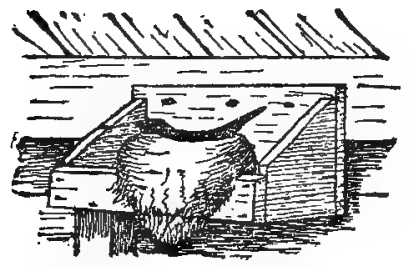

SHELF FOR PHGEB'S NEST

(Drawn by E. H. Forbush) to plates or rafters in barns, cellars, and low sheds.

\section{Barn Swallow. -} For barn swallows cleats may be nailed horizontally to the rafters of the barn, or bracket-shelves may be put up. A hole should be made in the barn and left constantly open, so that the birds may come in at will. Perhaps the scarcity of these birds in some localities may be due to the modern style of barn, with its tightly closed sides. An ornamental opening can easily be made in the gable, which will in no way detract from the appearance or use of the building. If desired, this can be closed during the winter. 
Eave Swallow. - For the eave swallows a long shelf or cleat may be fastened just under the eaves of a barn.

Chimney Swift. - It is worth while to experiment with the chimney swifts, by making artificial chimneys of wood in imitation of the old-fashioned chimneys so commonly frequented by these birds. A few cleats nailed horizontally may assist the birds in attaching their nest. Such a box may be placed anywhere on the roof. This board chimney has been successfully tried.

Nesting-material. - There are still other birds, which, while they will not allow us to choose the exact site of their nest for them, may sometimes be induced to locate their nest in our immediate vicinity if some materials which can be utilized in the construction of the nest are placed in a conspicuous place which is easily accessible. A careful examination of a large number of nests over large areas would probably show that there are few of our common species that do not occasionally use materials which have been manufactured by man, such as yarn, string, paper, etc. This follows naturally from the habit which many birds have of nesting near human habitations. There are certain species, however, which use an 
unusually large proportion of such material, - as the Baltimore oriole and the vireos. The chipping sparrow nearly always lines its nest with horsehair. In the nest of a kingbird, which was located in the gutter of a house, the following materials were found: strings, cotton, three kinds of cloth, tape, knit goods, and linen. Robins very commonly use large pieces of cloth.

Material to be exposed. - Some of the materials which may be exposed on fences, bushes, trees, etc., are the following: yarn, string, thread, rags, horsehair, straw, tufts of cotton and wool, small strips of cloth, pieces of grape-vine bark, feathers. The yarn, strings, etc., should be of sombre color, as these are preferred by the birds to the brilliant colors, which would tend to make the nest conspicuous; and these pieces should be cut into lengths of not over twelve inches, lest the birds become entangled and hang themselves. Tragedies of this kind do occur occasionally. If any of the material is taken by the birds, it furnishes opportunity for locating the nest, so that such means may be taken as are necessary to protect the occupants.

Mud. - The robin, swallow, and phobe use mud in their nests, so that if in dry seasons pans 
of mud are set in easily accessible but protected places, they may be found and used by these birds.

\section{Feeding Young Birds}

Many opportunities will occur in which some care must be given to young birds just out of the nest, either to protect them from cats or to furnish them with food. Occasionally wounded birds will be found, or nestlings forsaken by their parents, in which case it will be necessary to take entire care of the birds and feed them till they are able to look out for themselves. In a great many more cases, however, one will find young birds just learning to fly and unable to escape the clutches of the cat. This is one of the most critical periods in the life of the nestlings in this cat-ridden country. In such cases as these, which will be of frequent occurrence, it is necessary to protect the birds for a few days till they can fly, but in such a way that they can still be fed by the parents. The follow. ing plan is suggested in "Bird-Lore" by Elizabeth A. Reed :

"Mr. O. A. Stemple of Clearwater, Florida, has evolved a scheme which promises to save many young birds if bird-lovers will only put it in practice. It is simply this : Catch the young birds and put them into a clean flour-barrel standing in the shade of a tree near enough to the house to be easily 
watched. Leave it open at the top and put in food and a shallow dish of fresh water with the young birds. The parents will soon find and feed them, and when they are able to fly upwards and out of the barrel, they will take care of themselves. Of course they must be watched by day and securely covered at night until they are strong enough to fly out of their place of refuge."

This plan was successfully tried with some young cardinals, which were fed in the barrel by the female. If, however, the parents do not come to the barrel, the young should be fed about once an hour till the adult birds do resume their duties.

Another means of protecting the young birds is to place them in a cage with oilcloth over the top, and suspend it in a tree near the nest. The parents may then come and feed the fledglings through the bars. They should be kept in the cage a few days till their wings are stronger, and then released. But they should be watched and fed till the parents do come to the cage, so that if deserted they may be reared by hand. If the weather is cold or stormy, the cage should be taken down and put in a warm place during the night. In catching the young bird special caution should be taken not to frighten it. It is better to wait till the parents have ceased their cries of alarm and have departed for food, before attempting to take 
the young bird. One should approach slowly and lift the bird gently without any suggestion of grabbing. It will be useless to return the bird to its nest, but some plan such as previously suggested must be tried.

Kind of Food. - While even in cases of this kind it may be necessary to feed the young for a little while, instances will sometimes occur with wounded or deserted birds in which they must be fed entirely by hand till they are able to care for themselves. Meal-worms are the best food for insectivorous birds. "Ants' eggs" and mockingbird food, sold at the bird-stores, may also be used. Nearly all birds will eat grasshoppers and hairless caterpillars. Robins are fond of earthworms, and these will be eaten also by many other birds. Spiders seem to have a stimulating effect on the young birds. Bread and milk and the yolks of hard-boiled eggs will serve as a good substitute for insect food. Finely chewed nuts and cooked meat and chopped lean meat will also be relished. The mixture used for rearing young martins, described on page 36, may also be used for insectivorous birds. It will probably be better to use several kinds of food, rather than to rely on one. While caring for the young birds, one must remember that they cannot pick up food 
for themselves, but it must be placed in their mouths, and they should be fed about once an hour during the hours of daylight. It may take several days for them to learn to feed themselves.

For a further discussion of this subject of taming and feeding birds the reader is referred to Hodge's "Nature Study and Life," Chapter xxI, from which many of the above suggestions are taken.

\section{Difficulties}

In attempting to induce birds to nest in houses, there are two difficulties met with everywhere, the cat and the English sparrow. The latter is much the more troublesome; the cat can be outwitted quite readily, but not so the sparrow, which possesses a persistence difficult to overcome. The cat brings trouble only after the houses have been occupied and the young hatched; the sparrow brings trouble weeks before the other birds are due to begin nesting, by preëmpting all claims to any available nesting-sites; and when other birds do return, the sparrows prevent them from attempting to nest in most cases, and keep up a constant quarreling with those birds that may begin nesting. In many cases they go even further and destroy the eggs and nestlings and adults of the native birds which may have succeeded in establishing themselves in a nesting-site. 
Outwitting the Cat.-The cat does its damage while the young are in the nest, by sneaking around and pawing out the nestlings, and oftentimes catching the parent birds as they are coming in or going out, or as they are defending the young. It also does much harm by catching young birds just out of the nest before they are able to fly readily. By observing a few simple precautions in the construction and location of the houses and their subsequent protection, it is possible almost entirely to eliminate the cat as an obstructing factor. In the construction of the house, if it is made deep, the hole located near the top, and the roof made to project well out as described on pages 18, 19, a nearly cat-proof house will be the result. When the young do leave such a house, they will be strong enough to learn to fly quickly. If the house is mounted on a pole which is slim and slippery, the cats will find it difficult to climb. But the surest protection, where the only approach to the house is up the support to which it is attached, may be secured by placing something on the support below the house, over which the cats cannot climb. This should be placed so high that the cats cannot jump above it from the ground. The simplest method is to wrap around the support a piece of tin or zinc, of such width that the cats cannot 
reach across it; from two to three feet is wide enough and possibly a narrower piece will suffice. To render it less conspicuous, it may be painted the color of the support. If more perfect protection is desired, a piece of zinc or wire-netting may be modeled in the shape of a

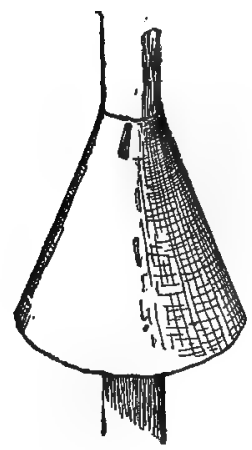

TIN OR ZINC CAT-GUARDS

(E. H. Forbush) cone with the large end down, as shown in the cut; or a circle may be cut out of the tin, of the same diameter as the pole, and the tin made to surround the pole like the brim of a hat. Another device is made by wrapping several strands of barbed wire around the support, attached to two pieces of board as shown in the cut on page 63, or a bunch of stalks of rose-bushes, or other branches with thorns, may be tied around the support. Still another method is to place a piece of heavy poultry-wire netting or a piece of tin on top of the post, at right angles to it.

One correspondent writes that the house wrens were successfully protected from the cat by using poultry-wire netting with an inch mesh. A piece 
was formed into the shape of a rather small, deep bowl and put over the front of the house, being securely tacked around. This held the cat at such a distance that it could not reach further than the entrance. In this case the netting was not put on till after the birds began to nest. Whether such an arrangement, if put on early in the season, would frighten the birds away, can be determined only by experiment.

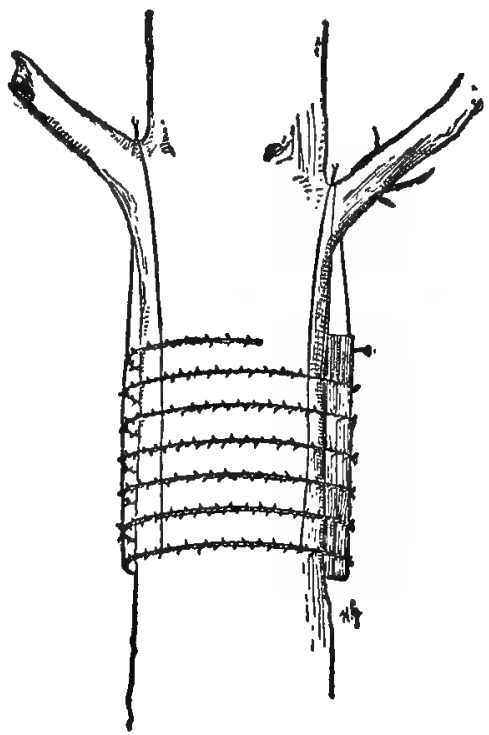

BARBED-WIRE CAT GUARD (From Lange's " Our Native Birds")

Traps for Cats. - If it is desired to settle the cat question permanently, a box-trap, baited with catnip, may be effective in enticing them into such small quarters that further disposition may be made of them.

Cat-proof F'ences. - In some cases it may be desirable to surround a yard with a fence to ex- 
clude cats. In the cut below is shown a cat-proof fence, the description of which is taken from Lange's "Our Native Birds": -

"To one who will go to the expense and trouble I recommend a fence of wire netting from 6 to 8 feet high. Near the upper edge of this netting fasten from six to ten wires, with close

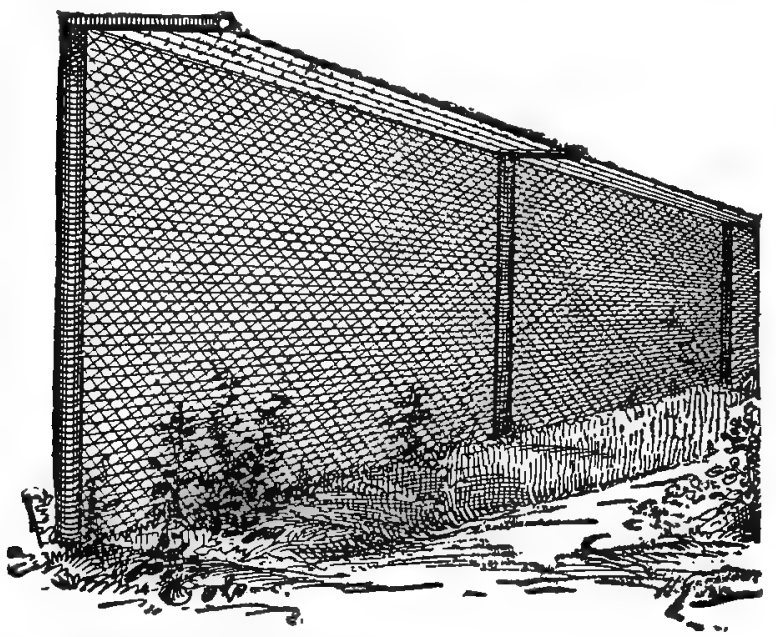

A CAT-PROOF FENCE, SEEN FROM THE OUTSIDE (From Lange's "Our Native Birds")

sharp barbs. The space between the barb-wires should be from $\frac{1}{2}$ to 1 inch wide. Another way would be to nail to the posts cross-pieces from 10 to 18 inches long. These pieces should project at right angles to the outside. Connect these 
cross-pieces by closely drawn wires or by wire netting. A few barbed wires should be strung along the outer horizontal edge of this fence. Cover the outer ends of cross-pieces by a coil of barbed wire. The meshes in the wire must, of course, not be too large, there must be no holes left near the ground, and no posts, walls or trees from which cats can jump into the enclosure. The appearance of such fences can be much improved by using them as a support for such annual climbing plants as do not form wood enough for cats to climb on. Instead of wire netting, a strong well-tarred fish-net six feet or more in height may be used with good results. From time to time the net must receive a fresh application of tar."

Mr. William Brewster at Cambridge, Mass., has an excellent cat-proof fence for a city garden. It is made of wire netting about six feet high, surmounted by a fish-seine of heavy twine, fastened to the top of the wire. The top of the net is looped to the ends of long flexible stakes. This gives so easily and furnishes so uncertain a footing that cats are not able to climb over it.

English Sparrow.- It is difficult for one who has had much experience with bird-houses to restrain his selection of words on referring to this 
persistent, quarrelsome, indefatigable nuisance, which brings to naught so many efforts in behalf of our native birds. The author feels very strongly on this matter, on account of his experience with children, as supervisor of naturestudy. The children easily become enthusiastic over building bird-houses, so that our suburbs and towns might soon become thronged with our beautiful and useful birds, were it not for the English sparrow. But whenever the children put out bird-houses, in the great majority of cases it is the sparrow which is the tenant; and after a few experiences of this kind both children and teachers naturally become discouraged and cease their efforts.

For a number of years the author has tried various devices for outwitting the English sparrow and has eagerly looked for any suggestion along this line. At the outset, he must confess that his efforts in this direction have proved mostly failures, but he will give the results of his experiences and of those of others concerning which he has been able to secure any record.

The various devices which have been used to combat the sparrow may be grouped into two classes: those whose purpose is simply to keep out the sparrows without harming them; and those which tend to decrease their numbers, 
or drive them away, by killing them. The author has taken a special interest in trying the first class of devices, as he was desirous of finding some method which could be recommended to children, which cannot be done of course with the second method.

Perches. - The first suggestion to which the author's attention was called was that the sparrows would not nest in houses not provided with perches. Universal experience shows that this is a useless precaution; the author believes, however, that it is a little better to construct houses without perches, which only tend to give the sparrows a better opportunity to stand by the entrance and annoy the other birds.

Boxes placed low. - Another suggestion, which also proves useless, is that if the boxes are placed near the ground, from eight to ten feet, the sparrows will become discouraged when they see that the houses can be reached from a chair. All the data that the author has been able to obtain indicate that this makes practically no difference in the nesting of the sparrows.

Trap-door on House. - A third suggestion tried was to trap the sparrow while in the house. 
A swinging cover was screwed just above the entrance, and a long string attached to this so that it could be pulled down and made to cover the hole. The house was watched until a sparrow was seen to enter, which was trapped inside. It was kept overnight and then the cover was removed; but the bird seemed in no hurry to leave the box, and it was only after renewed pounding on the box that she was driven out. Investigation showed that she was incubating her eggs, and that the trap-door merely forced her to do what she would naturally have done anyway.

Swinging Houses. - The device of a swinging house seemed at first to promise satisfactory results, because the principle had worked perfectly during a winter's experience while feeding birds on a swinging lunch-counter. In order to try this plan on a large scale the author visited the schools situated in the more favorable districts of the city where he lived, and explained the matter to the children and asked their coöperation. Some bird-cage springs were furnished to the children; but as the supply was soon exhausted, the children were told simply to suspend their houses by wire. As a little incentive, a prize was offered for the best account of experiences with the bird-houses. The children responded 
in large numbers with great enthusiasm, which showed how easily this locality might be made a paradise for birds were it not for the discouraging intervention of that annoying pest, the English sparrow.

In the fall statistics were gathered from the children relative to their experiences with the bird-houses, and the results are given below.

In 33 moving or suspended houses 34 pairs of birds began to nest (12 of bluebirds, 12 of wrens, 3 of robins, 1 starling, 6 of English sparrows); young were reared in 8 ( 2 bluebird, 4 wren, 2 sparrow); birds were driven away from 6 houses by the sparrows ( 3 bluebird, 2 wren, 1 robin). In three other moving houses the sparrows attempted to drive out the inmates, but were unsuccessful. They also tried to dislodge the starlings, but were unable to do so, one of the sparrows being killed in the fight.

In 27 stationary houses 25 pairs of birds began to build nests ( 13 of bluebirds, 7 of wrens, 2 of robins, 3 of sparrows); 15 reared young ( 8 bluebird, 5 wren, 1 robin, 1 sparrow); the birds were driven from three houses ( 2 wrens, 1 robin) by the English sparrow.

The results show that the English sparrows were not outwitted by the device of a moving house. The sparrows began to build in six of 
these houses and two pairs successfully reared young, and doubtless others would have done so, had they not been driven away by the children. In nine cases the sparrows attempted to drive out birds that had begun to build in the moving houses, and in six cases were successful.

The following season the author advised the children to build more houses for the wren, and make the hole so small that the English sparrow could not enter; in the fall statistics were taken and showed a large increase in the number of wrens nesting and a slight decrease in the number of bluebirds.

Of 43 stationary houses, the bluebirds reared young in 5, the house wren in 21, and the English sparrow in 7 . Of 12 moving houses, the bluebirds reared young in 3 , the wrens in 3 , and the English sparrow in 1.

During the third season, in 56 stationary houses, 56 pairs of birds began to nest (13 of bluebirds, 20 of wrens, 23 of sparrows); 34 reared young ( 7 bluebirds, 15 wrens, 12 sparrows). In 7 moving houses, 6 pairs began to nest ( 2 of wrens, 4 of sparrows); 3 reared young ( 2 wrens, 1 sparrow).

The results of the three seasons are summarized in the following table, which includes only those birds that reared young :- 


\begin{tabular}{|c|c|c|c|c|c|}
\hline & \multirow[b]{2}{*}{$\begin{array}{c}\text { Total } \\
\text { Number }\end{array}$} & \multicolumn{4}{|c|}{ Per cent occupied } \\
\hline & & Total & By Wren & By Blue- & $\begin{array}{c}\text { By English } \\
\text { Sparrow }\end{array}$ \\
\hline $\begin{array}{l}\text { Stationary houses } \\
\text { Moving houses }\end{array}$ & $\begin{array}{r}126 \\
52\end{array}$ & $\begin{array}{l}64 \% \\
34 \%\end{array}$ & $\begin{array}{l}32 \% \\
17 \%\end{array}$ & $\begin{array}{r}16 \% \\
9 \%\end{array}$ & $\begin{aligned} 16 \% \\
8 \%\end{aligned}$ \\
\hline Total & $\overline{178}$ & $56 \%$ & $28 \%$ & $14 \%$ & $\overline{14 \%}$ \\
\hline
\end{tabular}

These figures suggest that all the birds preferred the stationary house, and that by suspending the houses the percentage of sparrows using them was not decreased any more than the percentage of other birds.

The author's personal experience and that of others of whose observations he has been able to obtain records indicate that the moving birdhouse is not a very successful device for outwitting the sparrow; these experiences show, however, that our native birds will use such houses; and after careful consideration of all the evidence at hand, the author believes that they may help a little toward the desired end, as the sparrows seem to prefer a stationary to a moving house. But there is the probability, however, that the sparrows, though a little cautious at first, would soon become as accustomed to the latter as to the former.

Removing the Eggs. - The author has constructed his houses so that the top could be easily 
lifted, and he has tried removing both nest and eggs; but this plan has not proved successful, as the sparrows would begin building again the same day. Several observers have reported that if the nest is left undisturbed but the eggs alone removed, the sparrows become discouraged after a while and desert the box. The following is taken from Weed and Dearborn's "Birds in Their Relation to Man" :

Mrs. Mary Treat has recorded an ingenious experiment in discouraging the English sparrow on her premises. "A few years ago," she writes, " they were here in great numbers, driving bluebirds and wrens and martins from their boxes. At last I had boxes made on purpose for the plagues, with a hinged cover, and allowed each occupant to lay the requisite number of eggs, usually six, and commence to incubate, when I would destroy the eggs without disturbing the nest. At first the little simpletons, after making great ado, would in a few days thereafter again lay eggs in the same boxes. Sometimes over thirty eggs were laid in one box. But even the English sparrow finally learns prudence. Each year they appeared in diminished numbers, and last year only one pair attempted to preëmpt a box and they left after the first setting of eggs were destroyed, and the bluebirds and wrens had peace." 
The above was written about six years ago, and so the author wrote Mrs. Treat, inquiring whether her experience since that time had been equally successful, to which she replied:-

"Yes, I find removing eggs of the English sparrow a perfect success. None of the pests are allowed to hatch on my premises and it is very seldom they attempt it. They seem to have learned their lesson well."

Professor Forbush also writes that he considers it more effective to remove the eggs only rather than the whole nest.

This is the most promising suggestion of those that do not require the killing of the sparrow, that has come to the author's attention. The sparrows begin nesting so early that many of them might be discouraged before the native birds were ready to begin.

This method of repeatedly destroying the eggs for a few years offers an opportunity of reducing the number of sparrows without resorting to killing them, where a systematic effort is made throughout a whole locality, or possibly just in large parks.

Keep Holes covered. - The advantage which the sparrows obtain over our native birds by being with us all the year round and by beginning 
to nest so early, may be entirely neutralized either by taking down the houses in the fall and not putting them up till the birds return in the spring, or by covering up the holes after the, birds are through with the nest, and keeping the cover on till the nesting-time of the bird which we wish to induce to nest there. Or, as previously suggested, we may let the sparrows nest early and try to discourage them before the other birds are ready.

Small Holes. - There is considerable satisfaction in being able to record one device which is almost entirely successful in keeping out the sparrows, and that is, making the hole so small that the sparrows cannot enter, but large enough for the wrens and chickadees. An inch hole is large enough for the wren, and keeps out the sparrows; an inch and an eighth will do for the chickadee, and will usually keep out the sparrow, although the author finds observations recorded in which the sparrow entered even this size; but this is probably exceptional. Even with the wrenhouses there may occasionally be a little trouble. In one case the sparrow was seen to enlarge the hole till it was large enough for it to enter. In a few cases the sparrow is reported as staying around the house and troubling the wrens as they 
enter or leave. In the majority of cases, however, these small openings seem to have been effective in keeping out the sparrow. To what extent, however, wrens may even then become discouraged through the presence and persecution of the sparrows, it is difficult to say.

As a means of keeping the English sparrow out of the martin-houses it has been suggested that the entrance be placed underneath. In one case in which this was tried by making holes underneath the jut of an old house, it worked well the first year, being used by the martins, but not by the sparrows; it was not so successful the second year, and now the sparrows have taken all the holes. However, this plan might be tried elsewhere, not only with the martins, but also with the bluebird and tree swallow houses as well. It seems very probable that the swallows might be able to use such a house.

Killing the Sparrows. - The devices so far explained have sought to keep out the sparrows without injuring them; but there is one other plan left, namely, to trap or shoot them. After trying quite a variety of devices personally, and after reading the results of others' experiences, the author is forced somewhat reluctantly to the conclusion that this is the only successful way to 
deal with this pest, - reluctantly, because it cannot be recommended to children, who are among our most enthusiastic, as they are our most numerous bird-protectors.

Shooting the Sparrows. - The kind of frearm generally recommended is a small rifle, in which may be used the ordinary or fine shot-cartridge, although a shotgun may prove a more effective implement for one who is not a good marksman with the rifle. One correspondent suggests the use of an air-rifle, because it makes so little noise and thus lessens the possibility of frightening away desirable birds. If the sparrows become wary, the shooting may be done from the house through an open window, using smokeless powder. In this manner, too, very little noise is heard outside, and the other birds are not disturbed.

A very effective way to break up the nesting of the sparrows is to shoot only the females. This shooting should be started in the winter, so that on the arrival of the nesting-season, the males shall very greatly outnumber the females. This preponderance of males will render the successful mating of any pairs improbable, the success of this method depending upon the extent to which this preponderance in number of one sex over the other is maintained. 
In this connection the question has been raised whether shooting would not drive away other birds. But all the records which the author has been able to obtain, together with his own experience, indicate that this fear is entirely groundless. The native birds seem almost to understand and appreciate the help that is given them in fighting their enemy. Nor do other birds which nest in trees and bushes around the yard, such as chipping sparrows, robins, song sparrows, yellow warblers, etc., seem to be frightened by the shooting.

Trapping the Sparrows. - In cities, where the sparrows are most troublesome, there is usually an ordinance against the use of firearms, without special permission from the authorities. Another method of killing the sparrows, without the use of firearms, is to trap them. This method, together with the use of poisoned food, can be used to the best advantage, perhaps, in the winter, regarding which more will be said in the chapter on feeding winter birds; and if the flocks that frequent our yards during the winter are disposed of, there will be so many less to make trouble in the nestingseason. But the author would suggest the following plan for trapping them in the spring. He has not yet tried it, nor does he know whether 
it has ever been attempted, but he believes it is worthy of a trial. The plan is to make the nesting-houses bird-traps. Arrangements may be made whereby the weight of the bird as it entered would release a catch which would trap the sparrow inside. This could be arranged by having a false bottom suspended about an inch above the true bottom, in such a way that the weight of the bird on this would cause a cover to fall, closing the entrance.

Another arrangement, which may be more easily made, is to attach a swinging cover to the outside of the house beside the hole, with a long string fastened to the cover by means of which it may be pulled down to close the hole and trap the sparrow. This may be done either at night or at any other time whenever the sparrow is found inside. At first the birds may be cautious of this addition to the box, but they will soon become accustomed to it and enter the box as usual.

The house should be so arranged that it can easily be taken down and immersed in water, to drown the sparrows. And, indeed, it is well to put up all bird-houses so that they may be easily removed. For this purpose the following method is satisfactory: A strip of wood a little longer than the house is attached to its back. At each extremity of this strip is made a narrow slit about 
two inches long and a half-inch wide. Two large staples are driven part-way into the support on which the house is to be placed, at such distance apart as to fit into the slits. Wooden plugs are then whittled out to fit into the staples, thus holding the box firmly in place and also allowing it to be quickly and easily removed.

In a Farmers' Bulletin recently issued by the Department of Agriculture is given the suggestion that the sparrows may be caught at night by means of a long-handled net with a deep bag and a hoop of the right shape to fit over the front of the house. By rapping on the box the occupant may be driven into the net. 


\section{CHAPTER III}

ATTRACTING THE WINTER BIRDS

IN making plans for attracting the winter birds, one needs to consider four things : the kinds of food to be used ; methods of exposing it ; means of shelter from the severity of the weather; and the protection of the birds from their enemies. A study of the habits of the birds which we expect to attract will give the clue to the successful solution of the problems involved in these considerations. As regards their food, our winter birds may be grouped in two classes, insect-eating birds, such as the chickadees, woodpeckers, nuthatches ; and seedeating birds, such as the sparrows and juncos. In general animal food will attract the first class and vegetable food the second, but insect-eating birds often eat vegetable food, and seed-eating birds often eat animal food.

Foods preferred

As far as possible one should put out the kinds of food which birds prefer, if one would be most successful; but in times of great hunger birds will eat many foods which under ordinary circum- 


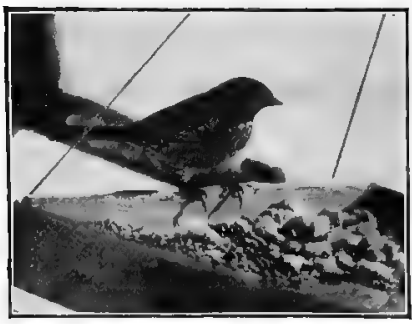

SONG SPARROW

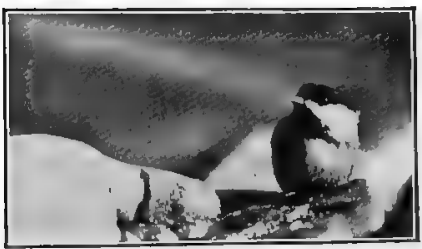

CHICKADER

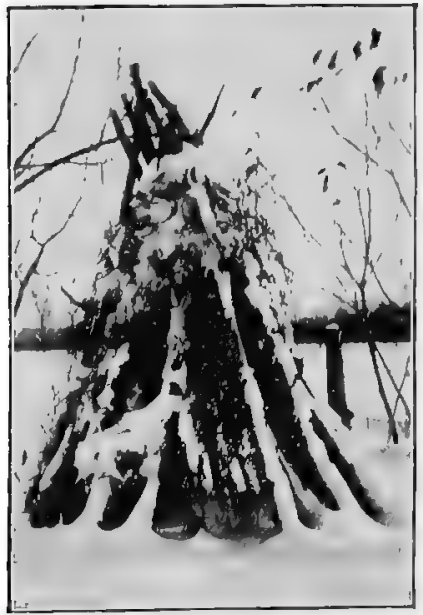

A BIRD'S TEPEE

made of bean-poles with the vines still attached

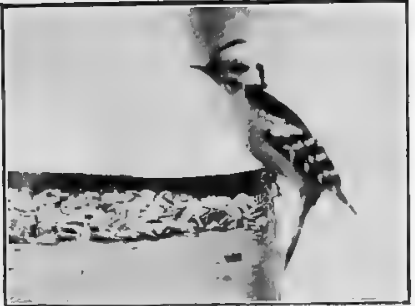

DOWNY WOODPECKER

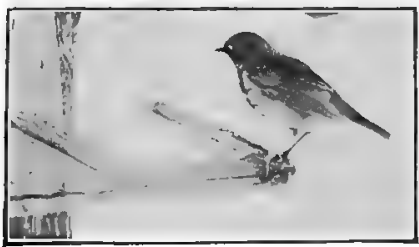

HERMIT THRUSH

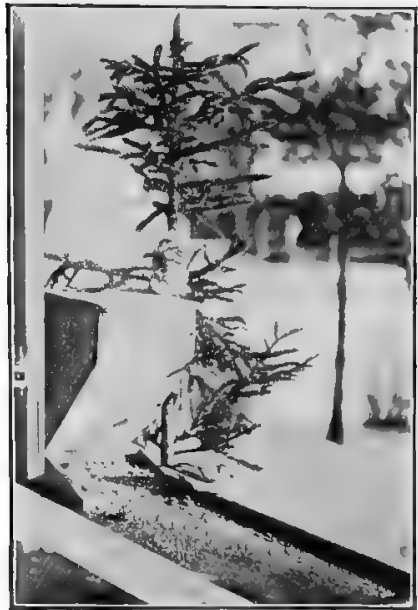

SELF-SUPPLYING FEED BOX 

stances would not be attractive to them. The various records to which the author has had access indicate that the same species, in different localities, may prefer different kinds of food. Following are some of the preferences shown by the birds as reported by different observers :-

"The chickadee preferred the raw pork rinds to the suet. However, nothing seems to tempt the appetite of these birds like the seeds of the sunflower." - A. C. Dike.

"The white-breasted nuthatch ate everything from cracked corn to suet, but seemed particularly fond of walnut meats." - Edwin C. Brown.

"Hungry birds will eat many things that do not belong strictly to bird-diet; but two articles I have found will suffice for all species, suet in good-sized lumps, that will not be torn to shreds too soon for the woodpeckers and all other tree-trunk-climbing birds, and any one of the various dog-biscuits, broken into pieces of various sizes, ranging from that of a chestnut, which jays and nuthatches love to pound up to suit their tastes, to crumbs that tempt the junco, tree sparrow, purple finch, snowflake, and even the robins and bluebirds; and the chickadee will take both meat and bread." Mabel Osgood Wright. 
"The woodpeckers eat nothing but suet, while the juncos eat nothing but crumbs and seeds. The birds have a decided preference for doughnutcrumbs, although they are very fond of breadcrumbs. The brown creeper likes crumbs and suet, while the chickadees and nuthatches, although they will eat anything I give them, like nuts and squash-seeds best. I crack nuts for them and give them shells and all, while I simply break the squash-seeds in two." - Samuel D. Robbins.

"There is no better food to attract jays than chestnuts. Whole corn comes next and afterwards meat.

"A first-class bird-food is the berry of the myrtle, bayberries; practically all birds eat them.

"Quail are fond of picking over hayseed and chaff for the weed and grass in it. In fact all the sparrows are as fond of this as of anything.

"I think that the Japanese barnyard millet is the favorite among all seeds for the majority of our birds in Massachusetts. Fox sparrows are fond of this. They took it from our shelf all winter. The white-throated sparrow is a glutton for Japanese millet.

"The goldfinch prefers sunflower-seeds to all others." - E. H. Forbush. 
The following table was made by the author's friend, Edward Uehling, as the result of a favorable winter with the birds. The author also had. frequent opportunity for observations at the same place and with practically the same results as recorded in the table.

Birds :

Brown creeper

Blue jay

Chickadee

Downy woodpecker

Hermit thrush Junco

Myrtle warbler White-breasted nuthatch

Tree sparrow White-throated sparrow
Foods eaten:

Suet.

Nuts, sunflower-seeds, bread, suet.

Nuts, sunflower-seeds, hemp-seeds, crumbs, suet.

Suet.

Suet, crumbs.

Crumbs, sunflowerseeds.

Suet.

Same as chickadees.

Crumbs.

Crumbs.

\section{Food preferred.}

Suet.

Nuts, seeds, and suet.

Nuts and sunflowerseeds.

Suet.

Suet.

Crumbs.

Suet.

Same as chickadees. Crumbs.

Crumbs.

The author has found suet to be the best animal food, being especially adapted for use in very cold weather, as it does not freeze readily. Small pieces, which might be otherwise wasted, may be melted together till they unite in one piece, and then allowed to cool. The best kinds of vegetable foods are found among the nuts and seeds. In the author's experience with winter birds, sun- 
flower-seeds have proved a great favorite even with some insectivorous species like the chickadee and white-breasted nuthatch, which often select these seeds in preference to meat.

Birds tamed to eat from the Hand. - The kinds of food which birds have eaten from the hand may also suggest another way of ascertaining the kinds of food preferred, as evidently the birds need some special inducement to alight on the human hand, at least, for the first time. The following table summarizes in brief form the records which the author has been able to find of winter birds which have become so tame as to feed from the hand. In some of these cases the birds took the food from the hand in preference to other kinds lying near.

\section{BIRDS FEEDING FROM THE HAND}

Number
Name of Bird. $\quad$ of Records. $\quad$ Food used.

Chickadee

Red-breasted nuthatch

White-breasted nuthatch Redpoll

Tufted titmouse

Oregon jay

Whiskey Jack

Erening grosbeak

Bluebird

Chipping sparrow
6 Walnut, beechnut, nuts, doughnut-crumbs, bread-crumbs, sunflower-seeds.

3 Beechnuts, doughnut- and bread-crumbs.

Walnuts, nuts.

1 Millet.

1 Nuts.

1 Fat.

1 Bread.

1 Not recorded.

1 Meal-worms (in spring).

1 Bread-crumbs " " 
Best Foods. - A study of these various observations indicates that the following are the best foods to use : suet, nuts, sunflower-seeds, cracked corn, doughnut-crumbs, bread-crumbs, hemp, dogbiscuit, squash-seeds, hay-seed, Japanese millet, bayberry. The fat trimmings from beefsteak may be eaten if hung up in trees. Bones as they are trimmed out, with a few shreds of meat and fat attached, may serve as a substitute for suet, especially if they are cut or broken open so as to expose the marrow.

Other foods which have been reported as being eaten are: raw pork-rinds, meat-scraps, which had better be run through a meat-chopper, chaff from barn-floor or hay-loft, oats, bird-seed, buckwheat, boiled potatoes, and rice.

A piece of carrion hung up in the orchard or edge of the woods may serve as food for the crows and jays. The jays are also fond of chestnuts and corn. When the ground is deeply covered with snow, the grain-eating birds may have difficulty in securing grit which is needed in the gizzard for grinding the food. To supply this need, coal-ashes or sand may be put out.

Time to begin. - It is important that the food should be put out early, even by the latter part of October, before the supply of natural food 
becomes scarce, as the early supply may induce some birds to remain, which might otherwise pass on.

The food should also be supplied with regularity, particularly so during stormy or severe weather, so that the birds may be able to find a supply at all times. Care should be taken, in the use of such foods as decay or sour easily, to see that the spoiled food is removed and a fresh supply provided; at times it may be well to supply water.

Species of Birds feeding.-From the records which have been available to the author, the following table has been compiled showing the kinds of birds which have eaten the food placed on or near buildings, the number of times recorded, and the kinds of food eaten by the species.

The table includes the reports of forty-five $\mathrm{ab}$ servers, representing fourteen states, chiefly in the northeastern section of the country. The birds are arranged in the order of the frequency with which they have been reported. Of the forty-three species here included, eighteen have become sufficiently tame to feed from a window and eight fed from the hand. 


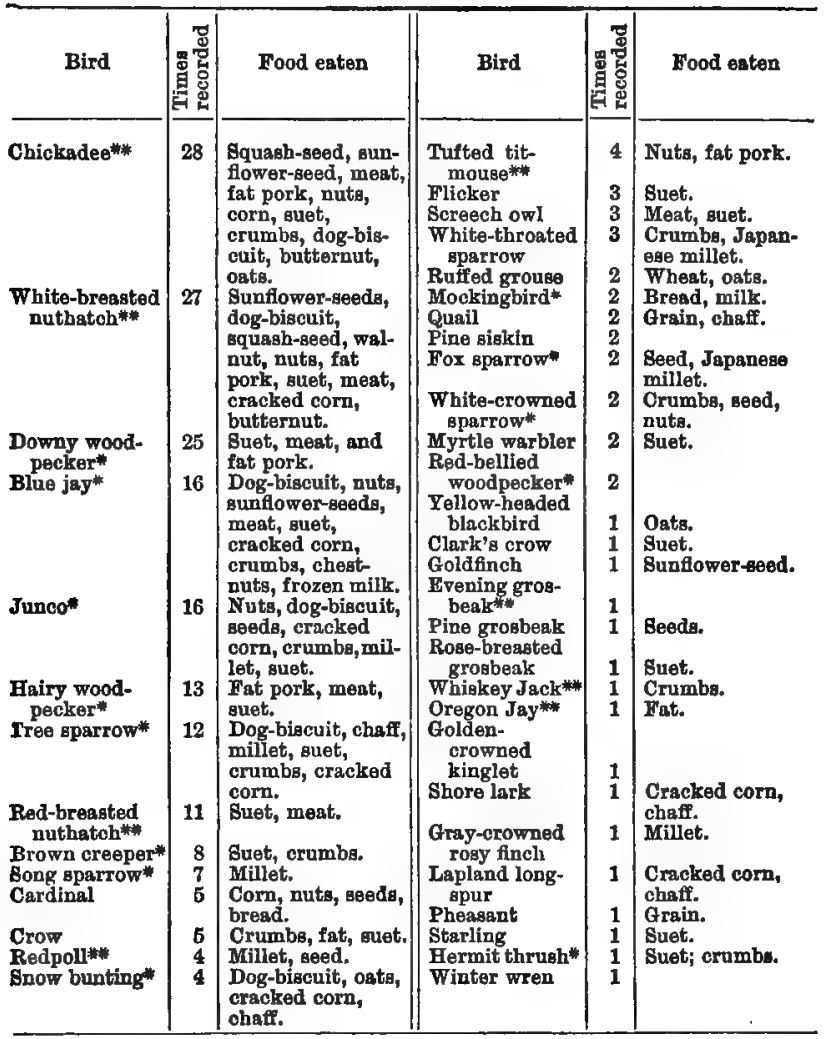

(Single asterisk, fed from window ; double asterisk, fod from hand.)

In the following table is briefly summarized the number of species which have been reported as feeding upon various kinds of foods. From this it will be observed that the four staple articles of 
food are suet and fat, nuts, crumbs, and various kinds of seeds.

\begin{tabular}{l|c||l|c}
\hline \multicolumn{1}{c|}{ Kind of Food } & $\begin{array}{c}\text { No. of Species } \\
\text { Eating }\end{array}$ & Kind of Food & $\begin{array}{c}\text { No. of Species } \\
\text { Fating }\end{array}$ \\
\cline { 1 - 3 } Suet & 15 & Meat & 5 \\
Crumbs & $\mathbf{1 2}$ & Dog-biscuit & 5 \\
Nuts & 10 & Chaff & 4 \\
Corn & 8 & Oats & 3 \\
Millet & 8 & Sunflower-seeds & $\mathbf{3}$ \\
Seeds & 7 & Squash-seed & 2 \\
Fat pork & 7 & Grain & $\mathbf{2}$ \\
\hline
\end{tabular}

From these reports we may conclude that, to attract the downy and hairy woodpeckers and the red-breasted nuthatch, we must depend entirely on animal food, while for the chickadee and whitebreasted nuthatch, a great variety of foods may be provided, both animal and vegetable. For the members of the finch family, we must use vegetable food almost entirely.

Feeding Spring and Summer Birds. - If food is kept out during the early spring, even after the winter birds cease to use it, some of the early spring birds may come to feed on it. The following have been reported as doing so: Pine warbler, blackbird, catbird, purple finch, robin, bluebird, Baltimore oriole. In a number of cases where food was kept out during the late spring, birds which nested in the vicinity carried this food to 
their young, and after the young left the nest they were brought there to feed. This has been noted of the catbird, robin, downy woodpecker, titmouse, and bluebird. A number of observers have found that by keeping out food constantly, birds which have fed during the winter months have remained to nest either in bird-houses or in some neighboring site, such as the chickadee and red-breasted nuthatch. One observer reports that the chickadees feed on suet more or less all the spring, and that the male feeds the female with it while she is on the nest. Another reports that robins, song and chipping sparrows, and catbirds appropriated suet, and catbirds and downy woodpeckers used it to feed their young.

If oats, wheat, or cracked corn are thrown out during the spring on the hard ground in the yard or paths, blackbirds, thrushes, and sparrows may be attracted, and some may remain to nest in the vicinity.

In "Bird-Lore," Dr. Hodge cites an instance in which a pair of bluebirds were induced to nest in a particular bird-house by being fed with mealworms. They became so tame that both fed from the hand and the female would perch upon it. The pair nested in a neighboring house, and came daily to the window-sill for food till the first brood left the nest. A full account of this very 
interesting experience is given in volume $\mathrm{vI}$, number 2 , of " Bird-Lore."

\section{Method of putting out Food}

On Tree-trunks. - There is a great variety of ways in which the food may be put out, depending upon the kind of food and the habits of the bird it is desired to attract. Pieces of suet may simply be nailed to tree-trunks, but as this is easily broken off and lost, it is better to wind a string around it, or place a piece of poultry-wire netting over it. This holds it in place much better and does not interfere with the birds in obtaining it. To the suet thus placed may come the trunk-climbing birds, such as the woodpeckers, nuthatches, brown creepers, and chickadees.

Ground. - To supply seed-eating birds, a bit of ground may be swept clear of the snow, and chaff, crumbs, and the various kinds of grains and other seeds scattered here. To this may come such birds as the sparrow, junco, snow bunting, blue jay, and quail. This food may be protected as shown in the illustration. A large brush-heap covered well with evergreen boughs, with grain thrown under it, does very well.

Tree-shelf. - The plans so far mentioned are very simple and require very little preparation; but 


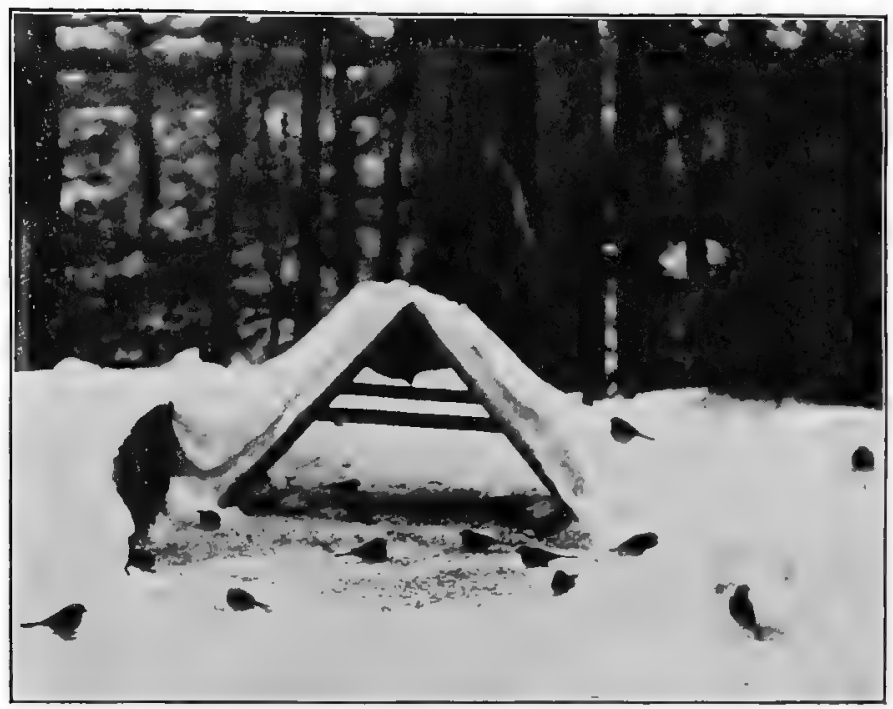

SHELTER FOR BIRDS' FOOD

Fifteen birds feeding, - song sparrows, tree sparrows, juncos

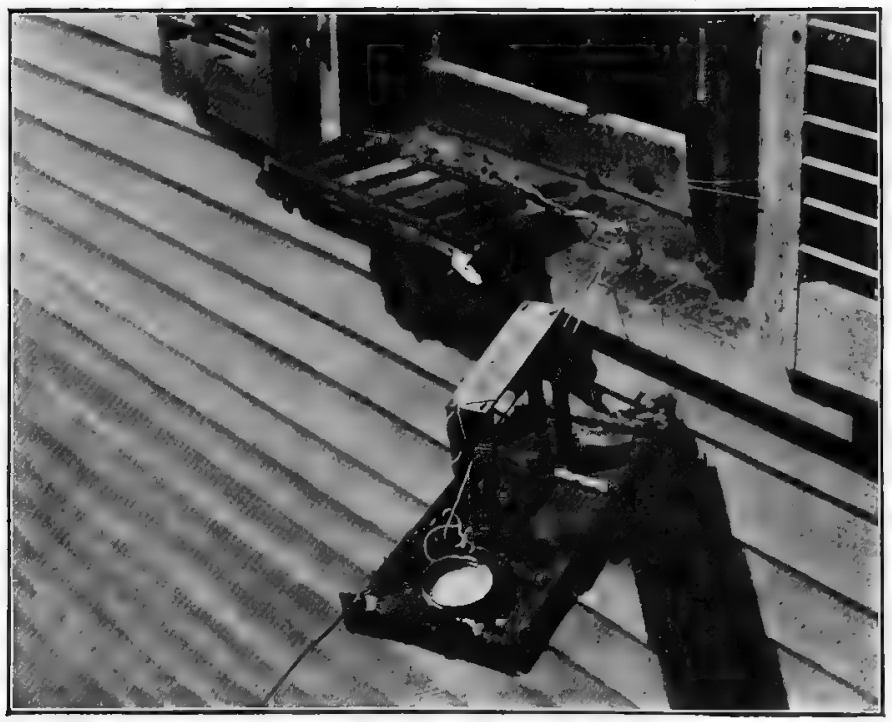

WINDOW AND MOVING FOOD-SHELVES 
it is well worth while to take the little trouble necessary to prepare a special kind of lunch-counter where the birds may be assembled and studied more closely. In its simplest form this may consist of a board attached to a tree, with a narrow strip around the edge to prevent the food from being blown off. Small holes should be bored in this to allow the water to drain out. This may be placed at first at a little distance till the birds become accustomed to coming to it, and then brought gradually nearer the house.

Window Shelf. - The shelf may be placed at a window, and many birds will become so tame that they will feed here even when a person is sitting by the window inside. This shelf should be wide, so as to allow room for a number of birds to dineat once. If covered with burlap, the small seeds and crumbs will blow away less easily. It would doubtless be worth while to arrange some kind of awning or roof over this to keep off the snow, so that the birds might be able to find food during the storms. The combination of food and shelter would evidently offer a stronger inducement to the birds than food alone. An interesting device is to attach a small tree to the shelf. On the branches suet, bones, etc., may be fastened, while any kind of food may be placed on the shelf. 
This arrangement has been used by Mr. Forbush with great success.

$B o x$. - An open box with a strip across the lower side of the opening may be placed on a tree with the back toward the stormy winds. Food may be kept in this box, which will also serve as a shelter.

Cocoanut. - Dr. A. K. Fisher writes of a cocoanut placed in one of the trees near his camp on the banks of the Potomac: "The cavity of the cocoanut is filled with fresh pork and the fresh kernels of the black walnut. Chickadees, tufted titmice, nuthatches, downy woodpeckers, juncos, and possibly one or two more species, take their meals at this restaurant during the winter."

Suet-box. - If suet is placed out loose without protection, it is often wasted by the blue jay and other larger birds.

The description of the following ingenious device for preventing the waste is taken from the account of Mrs. Rebecca H. Kauffman in the Illinois "Arbor and Bird-Day Manual" for 1908: "To remedy this waste of suet, the other members of my family assisted me in devising a suetbox. It is made of half-inch pine, 9 inches long, 6 inches wide, and 3 inches high. The lid is 
hinged on with leather and fastened down with a leather strip in which a slit is cut fitting over a small staple driven in the box. The lid is sawed out, leaving about three quarters of an inch around its outside edge. Into this edge all around, about a half-inch apart, are driven brads an inch long. On these brads from side to opposite side, first across the length and then across the width, cord is stretched. The common cord of the grocer will do, but stronger will last longer. The birds sit anywhere on the box and eat through the interstices made by the cross-cords. A new bird is a little shy in its first visits, but after that shows no hesitancy in eating all it wants. The box is nailed to a six-inch-wide board, and that to a stout strip spiked to the trunk of a tree, near a limb, so that the birds may have a place to wait while another visitor is satisfying its hunger.

"I leave suet in the box all the summer. The Baltimore oriole likes it greatly and likes to swing on a bit if it gets loose on a string. The birds come to eat it while nesting, even the robin, and sometimes bring their young to feed them on it, stuffing a morsel down the throat of their fluffy offspring."

Moving Shelf. - On the whole the most satisfactory plan which the author has tried is a shelf 
moving on a wire. The details of this have been worked out very ingeniously by Master Edward Uehling, who, at the time this work was done, was a boy in the eighth grade of school. The author was closely associated with him in this work and tried a similar device at his own home. Some of the most successful results of which the author has known in this latitude resulted from this plan as worked out by his friend during the winter of 1906 and 1907. A wire was put up, sloping from a second-story window to a tree about forty feet distant. On this wire, by means of two pulleys set in a frame, was suspended the lunch-counter partly covered with bark. In one corner was placed a dish for holding water. To this frame a string was attached and run to the window. The slope of the wire carried the counter toward the tree, so that it could be kept in any desired position along the wire. On this were placed suet, nuts, sunflower-seeds, and other foods. At first this was allowed to remain out at full length of the wire, touching the tree. Tree-climbing birds soon found this and came regularly to feed from it. After the birds had become accustomed to coming to the counter in this position, it was drawn up a little nearer each day, till at the end of about a month it had been pulled to the window. Those birds which at first came to it continued to do so 
even when it was brought up near enough to touch the window. A shelf had meanwhile been fastened to the window, and henceforth most of the food was placed on this, although some food was kept on the ground and on a distant shelf for those birds which would not come to the window. By Christmas-time the chickadees had become so tame as to feed from the hand. On one corner of the window shelf was fastened an apple-tree limb to which suet was nailed. To this the tree-climbing birds came at once. The sides of the moving counter were covered with bark and several partitions were made of bark. This helped give it a natural appearance and also furnished a better means of support to which the tree-climbing birds could cling. The following winter a roof was placed over the trough, which partially prevented the food from being covered over by snow during storms.

Advantages of the Moving Counter.-A moving lunch-counter has several advantages. It is easy to pull in the counter and replace the food, especially during and just after a storm ; it furnishes an opportunity of gradually accustoming the birds to the nearness of buildings and people, till they may feed at the window, where their habits may be studied at close range. It furnishes 
complete protection from the attacks of the crafty cat, and a partial protection from the sparrows, which aroid it unless they are very hungry.

During the winter seven species of birds fed from the counter at the window-sill : the chickadee, white-breasted nuthatch, downy woodpecker, brown creeper, blue jay, hermit thrush, and myrtle warbler. Photographs were secured of all these species.

As an illustration of what happened at these lunch-counters under favorable conditions, may be given the following account of a day with the birds, in which the author and Master Uehling kept watch from before sunrise till after sunset, recording the kinds of birds coming for food, the kinds of food taken, and the counter from which the food was taken. The day (February 9) was cold and clear, and the snow deep. Three kinds of food were used: suet, sunflower-seeds, and bread-crumbs. They were put in four places: bread-crumbs on the ground, suet and breadcrumbs on a shelf attached to a tree about fifteen feet from the house, suet and sunflower-seeds on a shelf at the window, and on the moving counter, which was drawn up close to it. Observations lasted from 6 A. M. to 5 P. M. The first bird came at 6.42 , and the last at 4.33 , making an interval of about 10 hours. 


\section{A WINTER DAY WITH BIRDS}

\begin{tabular}{|c|c|c|c|c|c|c|c|c|}
\hline \multirow{2}{*}{ NAME OF BIRD } & \multirow{2}{*}{ 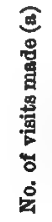 } & \multirow{2}{*}{ 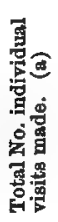 } & \multicolumn{2}{|c|}{$\begin{array}{c}\text { Percentage of } \\
\text { times food } \\
\text { chosen }\end{array}$} & \multicolumn{4}{|c|}{$\begin{array}{c}\text { Location visited, per } \\
\text { cent. }\end{array}$} \\
\hline & & & 泀 & 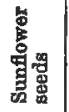 & 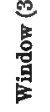 & 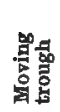 & 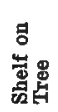 & 莡 \\
\hline Chickadee & 72 & 126 & 31 & 69 & 80 & 19 & 1 & \\
\hline $\begin{array}{l}\text { Junco } \\
\text { White-bregsted nut- }\end{array}$ & 55 & 179 & & (1) & & $\mathbf{2}$ & $\mathbf{5}$ & 93 \\
\hline hatch & 27 & 31 & 28 & 72 & 54 & 46 & & \\
\hline Blue jay & 18 & 24 & 28 & $5(2)$ & & 9 & 27 & 64 \\
\hline Hermit thrush & 16 & 16 & 31 & $(2)^{\prime}$ & & 20 & 30 & 50 \\
\hline Downy woodpecker & 6 & 6 & 100 & & & 100 & & \\
\hline English sparrow & 6 & 9 & & (1) & & & 9 & 91 \\
\hline Brown creeper & 2 & $\mathbf{2}$ & 100 & & & & 100 & \\
\hline Total & 202 & 393 & & & & & & \\
\hline Average per hour & 20 & 39 & & & & & & \\
\hline
\end{tabular}

(a) This distinction between these two columns is made because frequently several individuals of a species came at the same time, and to secure the figures in the second column, the number of individuals which came at each visit was counted.

(1) Only bread-crumbs were eaten.

(2) The remaining food was bread-crumbs.

(3) At some time during the winter all of these birds came to the window except the English sparrow and junco.

The number of different individuals of each species was estimated to be approximately as follows: 1 hermit thrush, 1 or 2 creepers, 2 or 3 woodpeckers, 4 to 6 nuthatches, 6 blue jays, 10 to 12 chickadees, 20 juncos. 
Shelter. - Provision should also be made for a winter shelter. The necessity for this is especially emphasized, particularly in the northern tier of states where the winters are severe. These shelters may prove especially welcome during storms, but may also be used as a roosting-place during the cold winter nights.

Mrs. Wright writes in "Bird-Lore": "As an experiment I have tried utilizing boxes, the size that holds one hundred pounds of laundry soap. On the front of the box a rough hood is fastened, with a drop equal to half the height of the box, and perches are placed across, three fourths of the way up, with pegs like stairs placed at intervals from the bottom upward. These boxes were placed in sheltered places, under the eaves of low buildings. ... .

"The first season they were unoccupied, but for two years, feathers and droppings show how well they have been appreciated by birds of many kinds and sizes, and this season I am thatching two of them with straw to make the shelter more snug and attractive."

Houses which are intended for nesting may serve as places of shelter if put out in the fall, and may possibly be the means of inducing some birds to remain and nest in them.

Some kinds prefer the shelter furnished by a 
tangle of vines and bushes, and if there are none of these on the place, piles of brush or cornstalks may serve as a shelter.

\section{Experiments in Germany}

Baron von Berlepsch, who has experimented for eleven years in Germany, says that three conditions are necessary for effective feeding of winter birds. "The sensible and effective method of feeding birds must (1) be readily accepted by those for whom it is intended ; (2) be carried out in all weathers: that is to say, the food must always be accessible to all birds, especially in the sudden changes of the weather, blizzards, winds, rain, and frost, and must always be in the best condition ; (3) it must be comparatively cheap : that is, the money spent on the food must really serve its purpose. The food must not be wasted or spoiled, but must be used by the birds to the last crumb."

Perhaps the chief lesson which we in America have to learn from this experiment in Germany is to make more adequate provision for protecting the food put out, instead of allowing it to be open and exposed to all kinds of weather.

Four devices for feeding birds have been used by Baron von Berlepsch: the "food-tree," "foodstick," "food-house," and "food-bell." 
Food-tree. - The food-tree consists of a coniferous tree on whose branches a mixture of hot liquid food is poured, which hardens as it cools. The chief constituents of this mixture are suet, hemp, white bread (dried and ground), meat, millet; the first two being the most important. Small quantities of other materials may be added, such as poppy-flour, oats, dried elder-berries, sunflower-seeds, and ants' eggs. The quantity of suet used is about one and a half times that of the total dry food. The suet is melted, and the other ingredients stirred in with it. While this mixture is boiling it is poured on the leaves and branches of the evergreen tree, the aim being to imitate a twig covered with insects' eggs and larvæ.

Food-house. - The food-house is a device which might well be adopted in this country. The main points of its construction are shown in the cut. This may serve as a shelter as well as a foodstation. There is a narrow strip of glass just under the roof on three sides. The purpose of the glass is to protect the food and throw light on the table, whose upper edge is on a level with the support which holds the glass. The purpose of the lower table is simply to attract the birds till they have discovered the upper table, on which the food is kept after the birds once begin to come. 
The dimensions of the food-house, as manufactured in Germany, and which experience has proved to be the best, are: width from post to

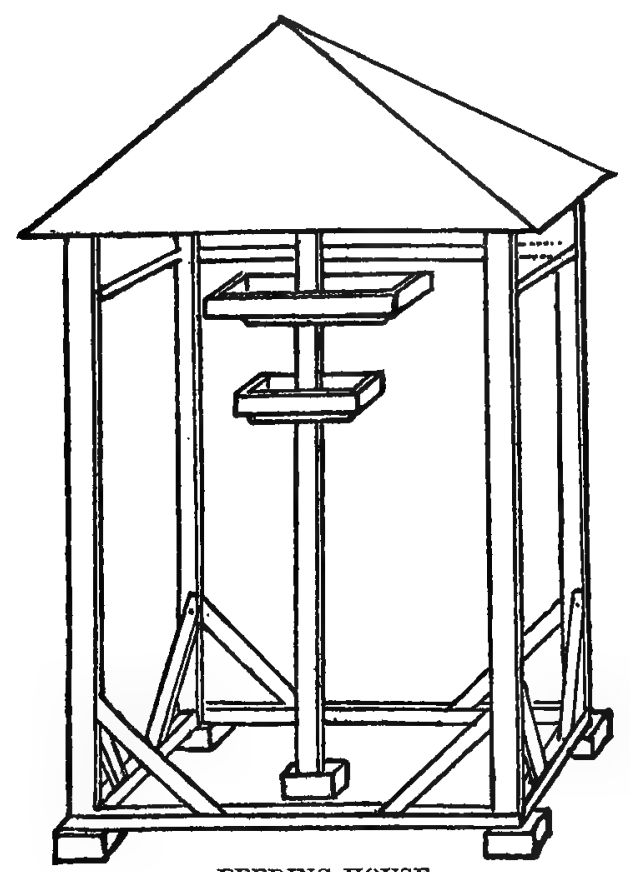

FEEDING-HOUSE

(From Berlepsch's " Der Gesamte Vogelschutz ")

post, four feet and three inches; height from ground to glass strip and upper edge of foodtable, four feet seven inches; width of upper food-table, two feet ; the space between the food- 
table and the glass strip, fourteen inches. This house will present a more natural appearance if several evergreen trees are placed near it. If some of the branches project under the house they may serve as sleeping-places.

Food-bell. - The dimensions of the food-bell shown in the cut are as follows: food-dish at

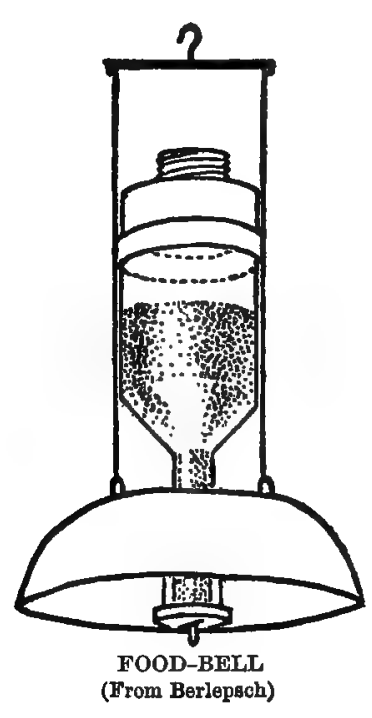
bottom, diameter two and a quarter inches, depth half an inch; tube, width one and a quarter inches; foodreceptacle, contents three and a half pints; and the metal bell, diameter one foot. The lower edge of the tube should be one sixteenth inch below the upper edge of the fooddish, and the upper edge of the dish one sixteenth inch higher than the edge of the bell. This works automatically as long as there are any seeds in the receptacle, which is made of glass, thus allowing its contents to be easily watched. It is filled by means of a lid which unscrews from the top. It is recommended 
that only hemp-seed be used in this, which Baron von Berlepsch considers is one of the best foods for seed-eating birds. In order first to attract the attention of the birds to this, two small nets filled with nuts or other food are hung from the inside of the bell, one projecting below the bell and one hanging just above the food-dish. One especially valuable feature about this is that it is generally avoided by sparrows.

\section{Difficulties}

The same two difficulties confront us here as in providing nesting-houses, the cat and the English sparrow. The birds may be easily protected from cats, by wrapping a piece of tin or zinc around the tree below the food; by putting the window-shelf at a second-story window; or by suspending the counter from a wire as explained on page 94 .

English Sparrow. - The sparrow problem, however, is not so easily solved. In one way the difficulty is not so acute as with the nestinghouses, where two birds cannot occupy the same apartment; for it is possible to furnish food for both the sparrows and other birds, but as a matter of fact experience shows that, where the sparrows congregate in large flocks, as is their custom, the other birds keep away. 
Suet on Branches. - A simple and somewhat effective device for keeping the sparrows away from suet is to fasten it on the under side of a limb, so large that the sparrows cannot stand on the upper side and reach it. If the limb does not slope more than forty-five degrees from the vertical, the tree-climbing birds will have little trouble in getting at it, while the sparrows will be quite nonplussed.

Moving Counter. - For other kinds of birds, some kind of moving counter seems to offer the best protection. Three winters ago the author's yard was so monopolized with a flock of English sparrows, that practically no other birds came to the food kept out. About the middle of the winter a lunch-counter was attached to a wire and suspended from a tree. The result was immediate and gratifying. The sparrows left at once and were hardly seen around again during the winter, while several of our native birds came freely to it. The author rejoiced, thinking that at last he had solved the sparrow problem; but the experiences of the following winter showed that no such simple device would long outwit such a crafty pest as the sparrow. By this time the sparrows had become accustomed to it and came quite freely to it. On another side of the house a 
counter was suspended from a wire running from a tree to a second-story window. About halfway between these two was placed a stationary counter; the author thought that, by supplying the sparrows with sufficient food at this counter, they might be tempted to leave the moving counters alone and allow the other birds to come to them. This surmise, however, proved only partly correct; for while the sparrows would eat from the stationary counter, in preference to the others, they would eat and waste such an enormous quantity of food, that even if the counter were heaped up with food in the morning, in a few hours it would be all gone, and then they would turn their attention to the other counters.

But during the first part of the season they did not often come in large numbers to the counter suspended from the wire. This was hung on only a single pulley, so that it was easily moved, being in almost constant motion; and when the wind blew strongly, the motion was accompanied by a creaking of the wire. When this was out at some distance from the house, a few sparrows came to it, but as it was brought nearer it was less frequented by them during the first part of the winter; but when the heavy snows covered most of their ordinary supply of food, they came in large numbers to both moving counter and window. 
Even to the stationary counter some of our more common native birds came quite regularly, but not often when the sparrows were there, although occasionally sparrows and other birds were seen feeding together.

Several observers have reported that the following kind of shelf is visited by our native birds, but not by the sparrows: A board is hinged to the window-sill and from the outer edge a string is run to the top of the window with a light spring between. Other observers have reported that the sparrows use it, and such has been the author's experience. Thus, while the moving counter is not entirely successful, it seems to offer a partial solution of the difficulty.

Trapping the Sparrows. - But probably the only permanent solution lies in destroying the sparrows, by trapping, poisoning, or shooting. Mrs. Bonner reports in "Bird-Lore" that the following device for trapping has proved very successful. A large wire rat-trap was secured, the kind that has the funnel-shaped entrance, the small end of the funnel pointing inward. On the floor of the trap were sprinkled grain or crumbs or any suitable bird-food, and a little more was sprinkled on the ground leading to the trap. In this the sparrows were caught and then drowned. 
Under a later date Mrs. Bonner writes that this method can be used successfully only at intervals, as the birds soon " catch on."

In a recent Farmers' Bulletin is given the following suggestion: To trap the sparrows a large shallow box is made open on one side and covered on the other with woven netting. The dimensions may be about 4 feet square and 6 inches deep. On a board a little larger than the box is placed grain to serve as a bait. Over this is placed the box tipped up on one edge and held up by a stick 18 inches long, to the upper end of which is attached a long string. The birds are fed here till they become accustomed to it and then are trapped by pulling out the support by means of the string. Through a small trap-door in the floor the sparrows may be allowed to fall into a pail containing sufficient water to drown them. In place of the box, some heary object may be used, such as an old door, to serve as a deadfall.

Poisoning the Sparrows. - During the winter the sparrows may be poisoned, if care is taken to see that no other birds eat the poisoned food. That they can be kept in check by systematic poisoning is shown by the experience of $\mathrm{Mr}$. Frank Bond, while a resident of Cheyenne, Wyoming. Each winter a regular campaign was waged 
and the numbers of the sparrows were so reduced that they did not interfere with the breeding of the native birds, which increased greatly in numbers with the growth of trees and parks. At the close of the winter's work there were never left more than thirty or forty sparrows, and sometimes even fewer. Mr. Bond has kindly contributed the following note regarding his experiences:

"I used whole wheat, well poisoned, as follows: Take one dram of strychnine crystals (usually sold in one-dram bottles) and thoroughly dissolve in one quart of water by boiling, using boiling water to begin with. A much more expeditious way would be to first dissolve the strychnine in an ounce or two of boiling vinegar, then add to the boiling water and boil well. Then add the wheat, enough to have the same just covered by the 'hell-broth,' set away until the water is entirely absorbed. The wheat will swell greatly. Then take out and dry carefully. I put the grain into a large dripping-pan, preparing several quarts at a time, and put into a warm oven stirring constantly to prevent scorching until perfectly dry. The grain will return to normal size and color, and one grain will kill an English sparrow in three minutes, often before it gets even into the crop.

"I scattered this grain sparingly where the 
birds fed, about stables where there were no chickens or pigeons, and especially about the grain-cars in the railroad yards which continually leaked wheat, oats, etc. On days, especially early mornings, after a fresh fall of snow I gathered in the little pests by the hundred.

"Of course I was authorized by the city government to carry on this work as I wished, but in the larger cities difficulty will be experienced in getting permission to use the poisoned grain. I believe, however, that care in its distribution would render its use in the large cities perfectly harmless to every bird, except the English sparrow, because the well-known habit of the species suggests the method. Every person who sees the sparrow at all, sees it at work upon the scattered piles of excrement distributed everywhere by the horse, sorting out and devouring with great relish the undigested grain, chiefly oats. A thimbleful of poisoned wheat dropped upon each small manure-pile in both the business and suburban sections, during the winter when forage is scarce, would probably in the large cities like Washington, kill from five to twenty birds. In studying the matter here, I am sanguine that with a few careful men to help, at least 90 per cent of the pests in this city could be killed within a month and at the rate of somewhere between 10,000 and 
25,000 per day, until their numbers became greatly reduced. But, alas! we are not allowed to use the grain, and there is no other way.

"I left Cheyenne six years ago, and I understand no one has carried on the work I handled alone for many years, and the sparrows have become a nuisance there as elsewhere. But while the English sparrows were killed off, the mountain bluebird and the house finch were among the most common bird-box occupants."

In Worcester, Massachusetts, Dr. Hodge has been able to keep the number of sparrows reduced during the winter, by using poisoned wheat.

The following directions are taken from his "Nature Study and Life": "My own formula is as follows: Dissolve one eighth of an ounce of powdered strychnine sulphate in one half pint of boiling water. Pour this while hot over two quarts of wheat (or cracked corn), stir well, and continue stirring, from time to time, till the liquid is absorbed. Dry thoroughly, without scorching, and put away in some safe receptacle, labeled, 'Poisoned Grain, Strychnine.'

"It requires but one kernel to kill a sparrow. A quart of wheat contains about 23,000 kernels, and the sparrows seldom take more than two or three. Expose the grain where poultry and tame 
pigeons cannot get it, and by operating only during the winter there will be no danger of poisoning seed-eating wild birds, at least for all Northern towns and cities. By taking advantage of the sparrow's gregarious habits and the fact that they drive off other birds from localities where they are numerous, much might be done even in the South.

"Sparrows are such suspicious and cunning birds, that, if the strychninized grain be exposed at first, they will probably roll each kernel in their bills, taste it, reject it, and possibly refuse to touch it again that winter. The best way is to select a place where the wind is not likely to scatter it away, a walk, a driveway, or porch-roof with a smooth surface, so that the grain may be swept up after each trial. Accustom them to feeding there daily with grain exactly like that which is medicated ( $\mathrm{I}$ often do this for a week, or even a month, until all the sparrows in the neighborhood are wont to come regularly), study the times when they come for their meals, and then on a cold, dry morning after a heavy snowstorm, having swept up all the good grain the morning before, wait until they have gathered, and then put down enough strychninized grain to feed the whole flock. You have about ten minutes before any begin to drop, and those 
that have not partaken of the grain by this time will probably be frightened off; but by timing it properly I have repeatedly caught every sparrow in the flock. I have found morning the best time, as they all come then; and it is essential to success to select a dry day, since in wet weather they taste the strychnine too easily; I have seen them actually throw it out of the crop.

"With this simple method at command, by concerted action a few friends of our native birds can rid any Northern city of the sparrow-pest in a single winter. This is no more than parents ought to do for the sake of the native birds, and if not for their sake, at least to clear the way for the children to do effective work in their behalf."

In a Farmers' Bulletin on "How to Destroy the English Sparrow," an even stronger solution of poison is recommended: "Put one eighth ounce of strychnia sulphate into three fourths of a gill of hot water and boil until dissolved. Moisten $1 \frac{1}{2}$ teaspoonfuls of starch with a few drops of cold water, add it to the poison solution, and heat till the starch thickens. Pour the hot poisoned starch solution over 1 quart of wheat and stir till every kernel is coated. Small-kerneled wheat sold as poultry-food is preferable to first quality grain, being cheaper and more easily eaten by the spar rows." 
Feeding the Shy Birds. - The directions given so far provide for the feeding of birds which may be attracted around our homes, but those which remain at a distance are just as much in need of protection. But while the first method of attracting birds may be carried on by an individual, in order that the second method may be at all effective it is necessary that there shall be coöperation of a large number of people.

Organization. - The following method of organization, as reported in "Bird-Lore" by E. H. Baynes, has been successfully used in several towns. A meeting is called by some enthusiasts for those interested in this line of work, effort being made to interest the school-children and those engaged in school work. At this meeting the need of feeding the birds should be explained and then committees appointed to look after the various details. One committee may look after the matter of securing food by direct contributions of food, or money to buy it, in which feature of the work the school-children may prove a great help. Another committee may be appointed to find volunteers to distribute the food. Boys from the upper grades or high school may prove good helpers. After the first heavy snowstorm the volunteers meet and divide 
into squads and assign the territory to be covered by each. Besides the grain and suet to be used for food, there will be need of snow-shovels and string. In localities selected for feeding-places the snow is cleared from spaces 10 to 20 feet square and the grain scattered here. The suet is tied to the branches of trees and the string is wound around it several times. In this way a number of feeding-stations may be established and kept supplied with food. The best feedingplaces may be found in the open fields where they will be easily seen. After every storm the snow should be cleared from these stations and a new store of food provided. And it may be necessary to distribute a fresh supply between the storms in case these are separated by more than a week. 


\section{CHAPTER IV}

\section{DRINKING- AND BATHING-FOUNTAINS}

Need of Water. - Water in large quantities is a necessity for bird life. Especially during hot weather do the birds require a large and constant supply, at a time when frequently the small pools or other common sources of supply may be entirely dry. In winter, snow may serve as a substitute; and in summer, dew and juicy food may furnish some of the necessary water; but these at best only partially provide the needed supply, which can be adequately furnished only by pools or streams, and more especially when the birds use the water for bathing as well as drinking.

During the dry part of the summer birds must often find it difficult to secure sufficient water, and this must be particularly true of young birds just learning to fly and unable to go on long journeys in search of water. To just what extent this is a factor in the mortality of birds, it is impossible to say, but that at times it may be a contributing factor there can be no doubt. The unusual places to which the birds have been 
observed to come for water indicate the straits to which they are at times driven.

In case one has a brook or pond near, there will not exist the need of furnishing drinkingfountains to save the birds from thirst; but these natural drinking-places are often surrounded with shrubs or tall grasses which furnish a lurking-place for cats, so that a fountain may be so arranged as to be better protected from the birds' enemies, and this will furnish opportunity for watching more closely the birds that come to it.

Essentials of Fountains. - The two essentials to be considered in providing fountains are the depth of water and the location of the fountain. The water should be very shallow. In most ornamental fountains the water is deep, and the sides so slippery that the birds are afraid to enter. The proper depth is about two inches in the deepest part, in the centre; and from there it should gradually slope to about a half-inch at the edge. Care should also be taken that the edge of the fountain is of roughened material so that the birds will not slip.

Location. - In deciding upon the location, the important matter to consider is protection from cats. When the birds' feathers are wet they 
fly with difficulty, and are easily caught. The fountain may be constructed in the ground, but if so, there should be no bushes near, from which skulking cats can jump out at the birds while they are bathing.

Fountains on Lawn. - In the illustration is shown the drinking-fountain on the lawn of Mr. C. D. Brown, of Rutherford, N. J. Mr. Brown writes of it: "All of the vegetation is contained in a portable wooden box six inches deep, and consists of hardy marsh perennials secured from the Hackensack Meadows. In spring the robins sometimes steal the mud for their nests so fast that the roots of the cat-tail, marsh-mallows, iris, foxtails, etc., are often exposed." Of a similar one on his own place, Mr. Chapman says, in "BirdLore," that it met with the approval of most of the birds in the vicinity of his house and was patronized even by screech-owls. "It is made of bricks and cement, and in cross-section resembles the appended diagram.

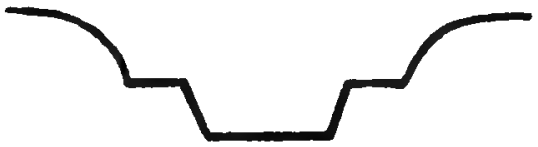

"Boards may be used to form partitions, which should be filled with earth. The plants introduced were sagittaria, iris, yellow pond-lily, wild 
rice, duckweed, and water-hyacinth. The pond is filled with a hose and is replenished as evaporation requires."

A bird-bath on the grounds of Mrs. W. M. R. French, of Beverly Hills, Illinois, is described as follows by Mr. Robert W. Hegner in "Bird-Lore": "A shallow hole was dug, two feet wide, three feet long, and eight inches deep. This was lined with small cobblestones laid in cement. The end away from the water-tap was made lower than the upper end, and the superfluous water ran down a slight incline to the roots of a large oak tree. Every day throughout the summer a swift stream of water was turned on from the garden-hose, which effectually cleaned the tub and left a clear, cool supply for thirsty birds. Blue jays, catbirds, bluebirds, robins, and wrens at once took possession, and not only were visitors but built their nests in the trees and bushes about the yard."

A large garden urn which stood on Mrs. French's lawn also served as a bathing- and feeding-place for birds.

The following description of a bird-bath is furnished by Orpheus M. Schantz of Illinois :-

"I dug a circular hole 20 inches deep by 33 inches in diameter in a corner of the lawn. I filled the hole to within about 8 inches of the top with cinders; next I put in a couple of inches of 


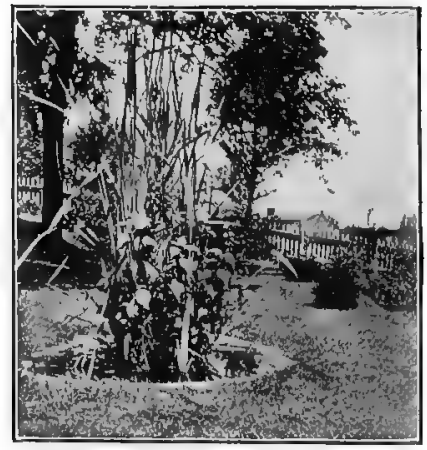

BIRD FOUNTAIN

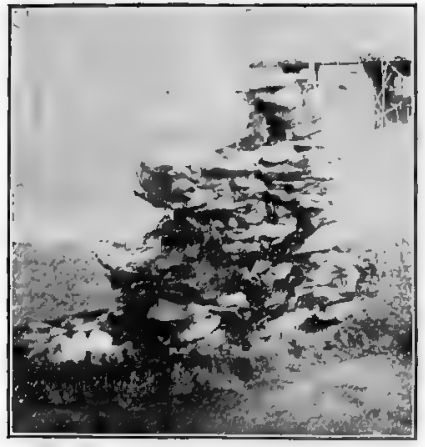

SCHOOL-YARD BIRD FOUNTAIN

Passaic, N. J.

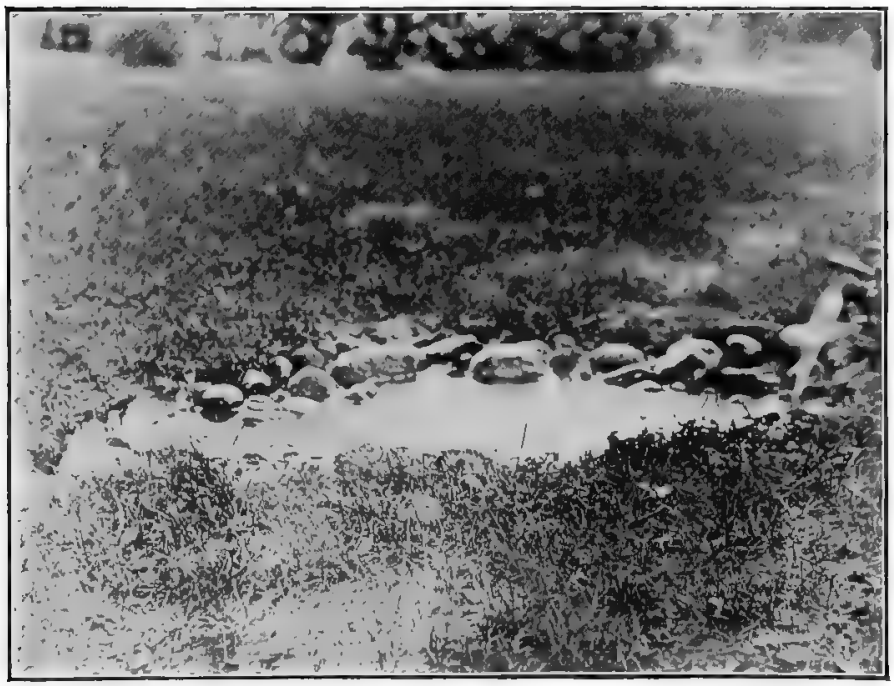

A BIRDS' BATH ON A LAWN 


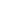


coarse sand and cement, and on top of that another layer of fine sand and cement, which, in the absence of a trowel, I smoothed out with my hands. The finished bath is about 33 inches across, with a rim about 2 inches wide and about one inch below the level of the surrounding sod.

"When the bath is filled, the water in the centre is about three inches deep and slopes gradually to the rim."

Pans for Fountains. - If one has the use of running water, there will be little trouble in providing a constant fresh supply. But simple and effective bird-baths may be made of almost any shallow receptacle, such as large flower-pot saucers, pans of various kinds, wash-boiler covers, etc. Sand and gravel should be placed in these, so as to give a range of depth of water from about a half-inch at the edge to about two in the centre. Or shelving rocks may be placed in the basin; these would render easier the change of water, which should be renewed each day, and would furnish a standing place for the birds which is better than the smooth edge of the pan. These pans may be fastened in the crotch of a tree, or placed on a post or window-sill, high enough to be out of the reach of cats. It is preferable to place 
it where it will be somewhat shaded to prevent the water from getting too warm.

Dr. Hodge's Fountain. - Dr. Hodge contributes the following description of his very successful and artistic fountain at Worcester. The fountain in the school-yard shown in the illustration is of the same type.

"The bird-fountain is the one great and perennial source of pleasure to ourselves and the birds. It draws all the birds within a radius of several blocks to our garden. Sometimes there will be 30 or 40 of several different species about the fountain, bathing or drinking or awaiting their turns. I have photographs which caught 8 within range of the focus at the same snap. If there was room for but one thing in my yard, it would have to be a bird-fountain. My fountain is constructed of the roughest rocks obtainable, laid up in Portland cement so as to give deep chinks and holes wherever possible for the mosses, lichens, liverworts, sundews, ferns, and all manner of wild flowers on and planted around it ; that is, a columnar heap of weathered rocks, held firmly by cement, which either does not show, or is blackened by mixing with lampblack so as to be inconspicuous. It has a bowl, about six inches in diameter and an inch deep, into which the water leaps in a purl- 
ing stream. This is about four feet from the ground. From this the water falls about a foot into the main bathing-bowl, about eighteen inches in diameter, built up with thin flat stones around the edge of a large flat stone. It is shallow at the edges all around and six inches deep in the centre, but is filled with sand and fine gravel, crushed stone, etc., so as not to be more than four inches deep in the centre. The water falls from this into a still larger pool which partially encircles the base of the fountain, and which is a foot deep in the middle and shallow at the edges. It can contain water-lilies, pitcher-plant, cat-tails, and arrowwort, and is overhung by gentians and cardinal flower, ferns and iris, jack-in-the-pulpit and bloodroot. It can all be arranged to have the music of running water with a very small stream.

"The idea as it has taken shape in my mind is to have a pile of natural rocks which hold pools of musical water, the whole set in a bosky dell of natural wild flowers to make the birds feel at home. A woodland spring is the type, in rocky ledges. True to nature throughout. Nothing produces the complete harmony - birds, wild flowers, mosses, ferns, rocks, trees - like the bosky-dell, woodland-spring idea. It is restful and beautiful enough to be the reason of its own being in and of itself, even if the birds do not add their charms." 
Floating Bath. - The author has seen the suggestion that floating basins may be placed in ponds where the conditions around the edge are such that the birds do not frequent them. This basin should be shallow and may be kept afloat by a wide wooden rim. No record has been found of the trial of a basin of this kind, so the author does not know how effective this would be.

As food kept out in the spring may be a means of inducing birds to nest in the neighborhood, so, too, drinking-fountains may help in bringing about the same results.

Visitors at Fountains. - The number of birds that visit a fountain during a season is very large. The number which will occupy bird-houses is comparatively small, limited by the natural nesting-habits of the birds; the number that may be attracted by winter feeding is larger, but still limited to those birds which have the ability to withstand our cold weather; the number that may be attracted by fountains is still larger, there being the possibility of enticing birds from the three great groups of migrants, summer residents, and permanent residents. One observer reports that 69 different species of birds, many rare warblers and migrants among them, came in one season to drink from a basin on a suburban lawn. 


\section{CHAPTER V}

PLANTING TREeS, SHRUBS, AND VINES

For one who owns a farm, or a place with fairsized grounds, on which he expects to live for a number of years, perhaps no greater returns in bird-life will be given than from a proper planting of trees, shrubs, and vines. A treeless and shrubless locality means a more or less birdless locality. These are essential to furnish nestingsites and shelter for most of our common birds. These plantings may serve a threefold purposeto furnish shelter, nesting-sites, and food for the birds - in addition to serving their purpose of ornamentation.

Plants for Shelter. - While all trees furnish some shelter for birds, the coniferous trees are specially valuable for this purpose on account of the retention of their foliage during the cold months, which furnishes some protection against the winter storms, and serves as a favorite roosting-place during the long cold nights. Windbreaks of any kind of trees may also serve as shelter. And the smaller plants, too, such as 
tangles of shrubs and vines, furnish retreats for many of the smaller birds when pursued by hawks; and serve as shelter for winter birds.

Plants for Nesting-sites. - While occasionally some birds seem to show a preference for some particular kind of tree or shrub in which to place their nests, usually it is a question of the general locality, with its surroundings and the food and protection given, which decides the bird in its selection of a nesting-site. So that those plants which will best serve the purpose of food and shelter will also furnish nesting-sites. A number of trees and tangles of shrubbery, thickly overgrown with vines, furnish the needed conditions for nesting-sites, provided the other factors are favorable.

In selecting trees we should not forget the elm, from whose graceful limbs the oriole so often hangs its swinging nest. If hedges are substituted for fences they may furnish nestingsites, and at the same time serve as a means of ornamentation.

Experiments in Germany.-Baron von Berlepsch has carried on some very successful experiments in Germany in planting shrubs and trees to serve especially as nesting-sites. In his shelter 
PLANTING TREES, SHRUBS, AND VINES 125

woods the area is first planted to shrubs, with trees scattered through them. These are allowed to grow for a few years, and then cut back and pruned so as to make whorls of branches to furnish foundations for nests. In the wood at Seebach, this treatment has proved eminently successful, as large numbers of birds nest in these growths, locating their nests chiefly in these whorls. In a similar way evergreens and avenues of trees are pruned to form whorl-shaped ramifications. Bushes with small stems are tied together to form crotches, and out of fifty bushes thus tied, forty-seven were occupied the first year. The Baron's experiences all indicate that the number of nesting birds may be largely increased by furnishing suitable crotches and nesting-places in shrubs and trees. It is certainly worth while to experiment along these lines in tangles of shrubbery, by pruning the bushes or tying them together so as to form crotches available for nesting-sites.

Plants for Foods. - In selecting our plants the question of food should receive first consideration. Some of our birds feed quite largely on fruits in their season, and a large number of them select fruits as a small part, at least, of their diet. The essential features regarding the 
fruit diet of birds are condensed into the accompanying table. This shows the kind of fruit eaten and the birds which feed upon the various kinds.

The table has been compiled largely from the studies on the food of birds made by the Biological Survey of the United States Department of Agriculture, but any other reliable records to which the author has had access have also been used, as Weed and Dearborn's "Birds in Their Relation to Man," and Dr. Hodge's "Food Chart of Our Common Birds." Messrs. E. H. Forbush and F. E. L. Beal have both contributed to the chart. A letter $F$ placed in a column signifies that this food is eaten by the bird in question. A double $F F^{\prime}$ indicates that the fruit forms an important article of food. As far as data have been available, the total percentage of the entire food which the wild and cultivated fruits form has been given.

In the table the birds and fruits are arranged alphabetically. Following that, is a list of fruits arranged according to the number of species of birds which eat them, and then a list of birds according to the numbers of species of fruit upon which they are known to feed. 

Chart of Fruits Eaten by Birds

\section{$\mathbf{F}=$ An ltem of Food \\ EF = An Important. Item of Food}

The flgures Indicate per cent of food

Blackbird, Crow

Blackbird, Red-winged

Bluebird

Bobolink

Cardinal

Catbird

Cedarbird

Chickadee

Crow

Cuckoo, Black-billed

Cuckoo, Yellow-billed

Finch, Purple

Flicker

Grosbeak,"Pine

Grosbeak, Rose-breasted

Grouse, Ruffed

Jay, Blue

Junco

Kingbird

Oriole, Baltimore

Oriole, Orchard

Phoebe

Quail

Robin

Sparrow, Fox

Song

\begin{tabular}{ll}
\hline " Tree \\
\hline " & White-crowned
\end{tabular}

"White-throated

Swallow, Bank

" Tree

Tanager, Scarlet

Thrasher, Brown

Thrush, Wood

Vireo, Red-eyed

"White-eyed

Warbler, Myrtle

Woodpecker, Downy

“ Halry

16

Yellow-bellied

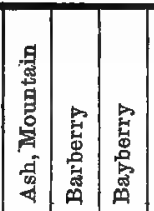

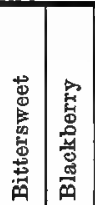

点

D

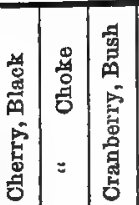

量

\begin{tabular}{|l|l|}
\hline$F$ & $F$ \\
\hline$F$ & $F$ \\
\hline$F$ &
\end{tabular}

$\mathrm{F}$

\begin{tabular}{|l|l|l}
\hline & & $F$ \\
\hline$F$ & & \\
\hline & & \\
\hline & &
\end{tabular}

$F$

\begin{tabular}{|l|l|l|}
\hline$F$ & $F$ & \\
\hline & &
\end{tabular}

$\mathbf{F}$

\begin{tabular}{|l|l|l|l|l|l|} 
FF & F & F & F & F & F \\
\hline
\end{tabular}

\begin{tabular}{|c|c|c|c|}
\hline & & & \\
\hline FF & F & & \\
\hline & & FF & \\
\hline & F & F &
\end{tabular}

\begin{tabular}{|l|l|l|}
\hline$F$ & $F$ & $F$ \\
\hline
\end{tabular}

\begin{tabular}{|l|l|}
\hline$F$ & $F$ \\
\hline$F$ & $F$
\end{tabular}

$\mathrm{F}$

\begin{tabular}{ll|l|l|l|l|l}
$F$ & $\hat{F}$ & $F$ & $F$ & $F$ & $F$ \\
\end{tabular}

\begin{tabular}{l|l|l|}
\hline$F$ & $F$
\end{tabular}

\begin{tabular}{l|l|l|}
\hline F & F & F \\
\hline
\end{tabular}

\begin{tabular}{l|l|l}
\hline$F$ & $F$ & $F$ \\
\hline
\end{tabular}

FF

\begin{tabular}{|c|c|c|}
\hline FF & & \\
\hline$F$ & $F$ & FF \\
\hline$F$ & & \\
\hline$F$ & & \\
\hline
\end{tabular}

$-+$

$+-1-1$

\begin{tabular}{lllll|l|l|l|l|l|l} 
& & & $F$ & & & & & & \\
\hline F & $F$ & F & F & $F$ & FF & & $F$ & $F$ & $F$ \\
\hline
\end{tabular}

\begin{tabular}{|c|c|c|c|c|c|c|c|c|c|}
\hline$F F$ & & $F$ & & $F$ & $F$ & & & $F$ & $F I$ \\
\hline$F$ & $F$ & & & $F$ & $F$ & $F$ & $F$ & $F$ & $F$ \\
\hline$F$ & $F$ & $F$ & & $F$ & $F$ & & & $F$ & $F$ \\
\hline
\end{tabular}

\begin{tabular}{l|l|l|l|l}
$F$ & $F$ & $F$ & $F$ & \\
& & & &
\end{tabular}

\begin{tabular}{l|l|l|}
\hline$F$ & $F$ & $F$ \\
\hline$F$ & & $F$
\end{tabular}

\begin{tabular}{|l|l|}
\hline$F$ & $F$ \\
\hline
\end{tabular}

\begin{tabular}{|c|c|c|c|c|c|c|}
\hline F & F & F & F & F & F & \\
\hline F & & & & F & F & \\
\hline F & & & & F & &
\end{tabular}

\begin{tabular}{ll|l|l|l|}
\hline$F$ & & & & $F$ \\
\hline
\end{tabular}

\begin{tabular}{l|l|l|l|l}
\hline & F & F & F & F \\
\hline F & F & F & F &
\end{tabular}

$F$

$+$

\begin{tabular}{|c|c|c|c}
\hline & & & $F$ \\
\hline & & & $F$ \\
\hline & $F$ & $F$ & $F$ \\
\hline & & & $F$ \\
\hline & $F$ & & $F$ \\
\hline & & & \\
\hline & & & $F$ \\
\hline$F$ & & $F$ & $F$ \\
\hline
\end{tabular}




\begin{tabular}{|c|c|c|c|c|c|c|c|c|c|c|c|c|c|c|c|c|c|c|c|}
\hline 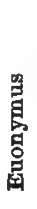 & 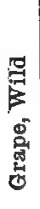 & 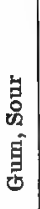 & 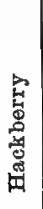 & 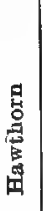 & $\begin{array}{l}\text { 룰 } \\
\text { 車 }\end{array}$ & 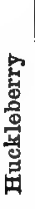 & 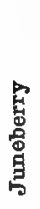 & 兽 & $\begin{array}{l}\text { 总 } \\
\text { 总 } \\
\text { 啹 }\end{array}$ & 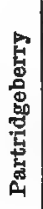 & 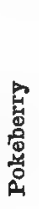 & 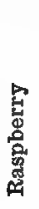 & 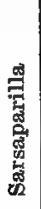 & 总 & 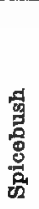 & 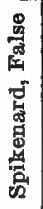 & 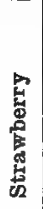 & $\begin{array}{l}0 \\
\text { 亶 } \\
\text { 员 }\end{array}$ & $\begin{array}{l}\text { 貝 } \\
\text { 晋 } \\
\text { 总 }\end{array}$ \\
\hline & $F$ & & $F$ & & & $F$ & $F$ & & $F$ & & $F$ & $F$ & & $F$ & & & & $F$ & \\
\hline & & & $F$ & & & & & & $F$ & & & & & & & & $F$ & & \\
\hline$F$ & & & $\mathrm{~F}$ & & $F$ & $F$ & $F$ & $F$ & $F$ & $F$ & $\mathrm{~F}$ & $F$ & & $F$ & & $\mathrm{~F}$ & $F$ & $\mathrm{FF}$ & $\mathrm{F}$ \\
\hline & & & & & & & & & $\dot{\mathrm{F}}$ & & & & & & & & & & \\
\hline & 12 & & $F F$ & & $F$ & & $F$ & & $F F$ & & $\vec{F}$ & FF & & $\mathbf{F}$ & $F$ & & $F$ & $F$ & $F$ \\
\hline & & $\mathrm{F}$ & & & & & & & $F$ & & $F$ & $F$ & & $F$ & & & $F$ & $F$ & \\
\hline & $F$ & & $F$ & & & $F$ & $F$ & $F$ & $F$ & & $\mathrm{~F}$ & $F$ & & $F$ & & & & & $F$ \\
\hline & & & & & & & & & & & & & & & & & & 4 & \\
\hline & $F$ & $F$ & $\mathrm{~F}$ & $F$ & $F$ & $F$ & $F$ & $F$ & $F$ & & $F$ & $\mathbf{F}$ & & $F$ & & & $F$ & $F$ & $F$ \\
\hline . & & & & & & & & & $F$ & & & & & & & & & & \\
\hline & & & & & & & & & $F$ & & & & & & & & & & \\
\hline & & & & & & & & $F$ & & & & & & & & & & & \\
\hline & $F$ & FF & $\mathbf{F}$ & $\mathbf{F}$ & $F$ & $F$ & $\mathbf{F}$ & $F$ & $F$ & & $F$ & $\vec{F}$ & $F$ & $F$ & $F$ & & $F$ & $F$ & \\
\hline & & & & & & & & $F$ & & & & & & & & & & & \\
\hline & & & & & . & & $F$ & & $F$ & & $F$ & $\mathrm{FF}$ & & & & & $F$ & & \\
\hline & 3 & $F$ & & $\mathrm{FF}$ & & $F$ & & & $\mathrm{~F}$ & $\mathrm{FF}$ & & $F$ & $\mathrm{~F}$ & $\mathrm{~F}$ & & & & FF & $F$ \\
\hline & $F$ & $\mathrm{~F}$ & & $\mathrm{~F}$ & & $F$ & $F$ & & $\mathrm{~F}$ & & $F$ & & & & & & $F$ & $F$ & \\
\hline & & & & & & & & & & & & & & & & & $F$ & & \\
\hline & $F$ & & & & & & & $F$ & $F$ & & $F$ & $F$ & & & $F$ & & & $F$ & \\
\hline & & & & & & $F$ & $F$ & & $F$ & & & $\mathrm{~F}$ & & & & & & & \\
\hline & & & & & & & & & $F$ & & & $F$ & & & & & & & \\
\hline & & & & & & & & $F$ & $\vec{F}$ & & & & & & & & & & \\
\hline & $F$ & & & & $F$ & $F$ & & & $F$ & $\mathrm{~F}$ & & $F$ & & $F$ & & & $F$ & 1.6 & $F$ \\
\hline$F$ & $F$ & $F F$ & $F$ & $\mathbf{F}$ & $F$ & $\mathrm{~F}$ & $F$ & $F$ & $\bar{F}$ & & $\mathrm{~F}$ & $\mathrm{~F}$ & & $F$ & $F$ & $F$ & $F$ & $F$ & $F$ \\
\hline$F$ & & & & & & & & & & & $\vec{F}$ & & & & & & & & \\
\hline & $F$ & & & & & & & & $F$ & & $F$ & $\mathrm{~F}$ & & & & & $F$ & & \\
\hline & $F$ & & & & & & & & & & & & & & & & & & \\
\hline & & & & & & & & & & & & & & & & & & & \\
\hline & & & & & & & & & & & & & $F$ & $\mathrm{~F}$ & $F$ & & $\mathrm{~F}$ & & \\
\hline & & & & & & & & & & & & & & & & & & & \\
\hline & & & & & & & & & & & & & & & & & & $\mathrm{FF}$ & \\
\hline & & & & & & & $F$ & & $\mathbf{F}$ & & & $\mathbf{F}$ & & & & & & & \\
\hline & $F$ & $F$ & & & & & & & $F$ & & $\bar{F}$ & $\mathrm{~F}$ & & & & & $F$ & & \\
\hline & & & & & & & & $F$ & $F$ & & & & & & & & $\mathrm{~F}$ & & $F$ \\
\hline & & & & & & & & & $F$ & & & $F$ & & & & & & & \\
\hline & & & & & & & & & $F$ & & & & & & & & & & \\
\hline & & & & & & & & $\mathrm{F}$ & & & & & & & & & & & \\
\hline & & $\vec{F}$ & & & & & $F$ & & $F$ & & $F$ & $\mathrm{~F}$ & & $F$ & & & $F$ & $F$ & $F$ \\
\hline & $\mathbf{F}$ & $\bar{F}$ & & & & & $\mathrm{~F}$ & & $\mathrm{~F}$ & & $\mathrm{~F}$ & & & & $F$ & & $F$ & $F$ & $F$ \\
\hline$\dot{\boldsymbol{F}}$ & $F$ & $F$ & $\mathrm{~F}$ & & $F$ & & $F$ & $F$ & & & $F$ & $\mathbf{F}$ & & $F$ & & & & & \\
\hline
\end{tabular}





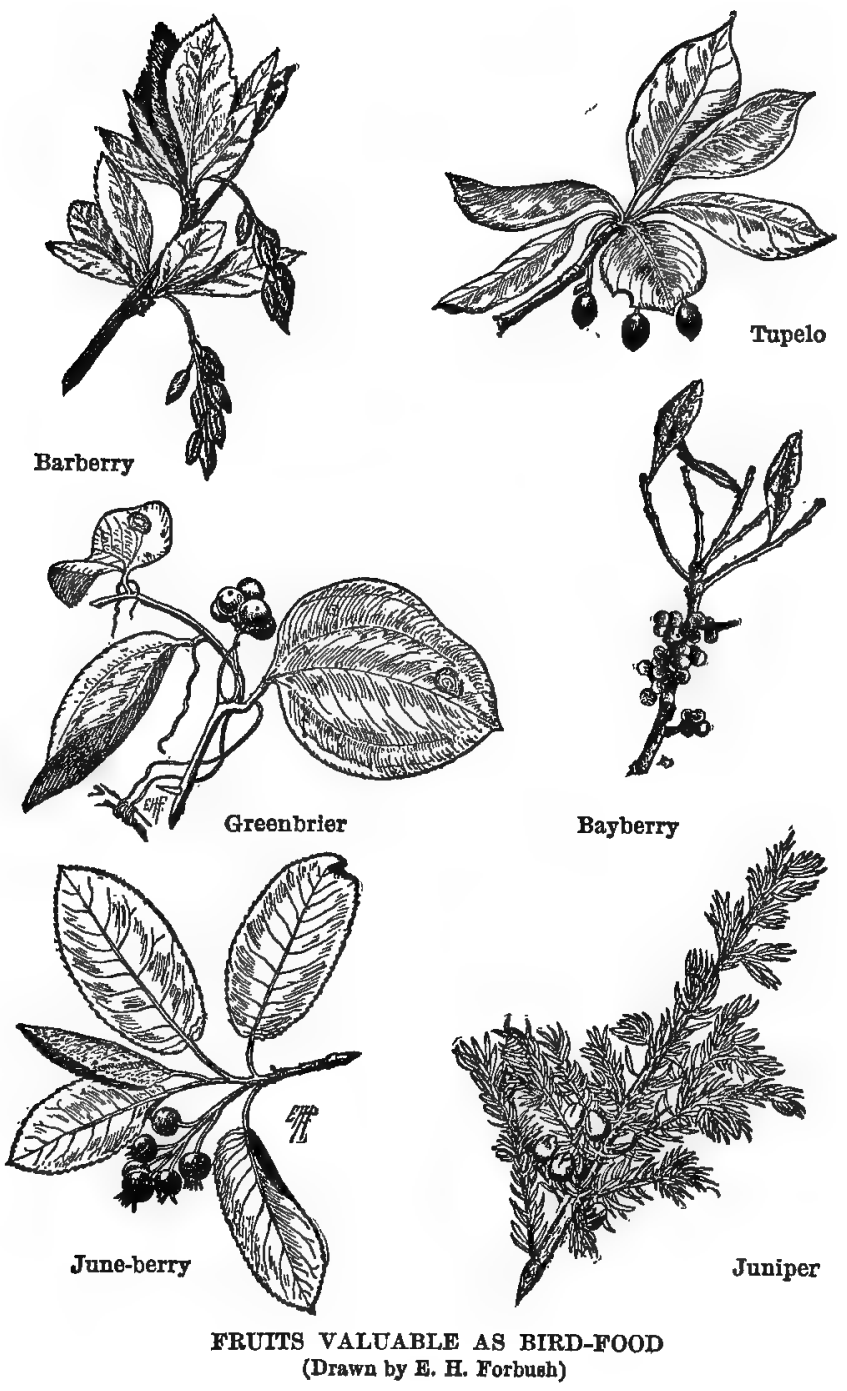


LIST OF FRUITS EATEN BY BIRDS

\begin{tabular}{|c|c|c|}
\hline Name & $\begin{array}{l}\text { No. of species } \\
\text { of birds eating }\end{array}$ & Date in fruit \\
\hline Blackberry & 30 & July \\
\hline Mulberry & 28 & June and July \\
\hline Elderberry & 27 & August and September \\
\hline Black cherry & 21 & August and September \\
\hline Raspberry & 20 & July \\
\hline Blueberry & 19 & July and August \\
\hline Dogwood & 19 & August and September \\
\hline Pokeberry & 17 & September \\
\hline Strawberry & 17 & June and July \\
\hline Red cedar & 16 & October - all winter \\
\hline Sumac & 16 & August - all winter \\
\hline Bayberry & 15 & All winter \\
\hline Wild grape & 15 & September to November \\
\hline Juneberry & 15 & June \\
\hline Choke cherry & 14 & July and August \\
\hline Smilax & 13 & September \\
\hline Virginia creeper & 12 & October \\
\hline Juniper & 12 & October \\
\hline Huckleberry & 11 & July \\
\hline Mountain-ash & 10 & September - all winter \\
\hline Buckthorn & 10 & August \\
\hline Sour gum & 10 & October \\
\hline Hackberry & 10 & September and Oetober \\
\hline Viburnum & 10 & September and October \\
\hline Barberry & $\mathbf{9}$ & September - all winter \\
\hline Holly & 7 & All winter \\
\hline Spice-bush & 6 & September \\
\hline Bittersweet & $\mathbf{5}$ & July \\
\hline Hawthorn & $\mathbf{5}$ & September \\
\hline Bush-cranberry & 4 & September and October \\
\hline Euonymus & 4 & Oetober \\
\hline Partridgeberry & $\mathbf{3}$ & October \\
\hline Sarsaparilla & $\mathbf{3}$ & July and August \\
\hline False spikenard & 2 & September \\
\hline
\end{tabular}




\section{LIST OF BIRDS ARRANGED ACCORDING TO THE NUM- BER OF SPECIES OF FRUIT EATEN}

(Figures indicale per cent of total food)

\begin{tabular}{|c|c|c|c|c|}
\hline \multirow[b]{2}{*}{ Name } & \multirow{2}{*}{$\begin{array}{l}\text { No. of spe- } \\
\text { cies of fruit } \\
\text { eaten }\end{array}$} & \multicolumn{3}{|c|}{ Percentage of food } \\
\hline & & $\begin{array}{l}\text { Vegetable } \\
\text { food }\end{array}$ & $\begin{array}{l}\text { Wild } \\
\text { fruit }\end{array}$ & $\begin{array}{c}\text { Cultivated } \\
\text { fruit }\end{array}$ \\
\hline 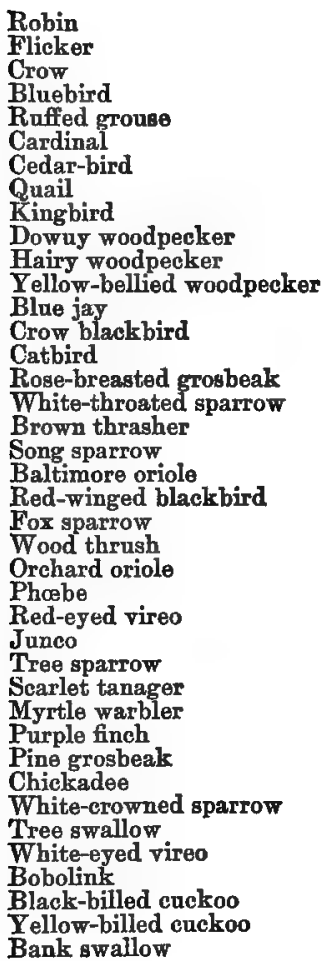 & $\begin{aligned} 32 \\
28 \\
25 \\
23 \\
23 \\
20 \\
20 \\
20 \\
18 \\
18 \\
18 \\
17 \\
16 \\
15 \\
15 \\
12 \\
12 \\
12 \\
11 \\
8 \\
6 \\
6 \\
6 \\
5 \\
5 \\
5 \\
4 \\
4 \\
4 \\
4 \\
3 \\
3 \\
2 \\
2 \\
2 \\
1 \\
1 \\
1\end{aligned}$ & $\begin{array}{l}58 \% \\
30 \\
57 \\
24 \\
89 \\
71 \\
87 \\
84 \\
10 \\
25 \\
31 \\
50 \\
76 \\
70 \\
56 \\
48 \\
81 \\
36 \\
66 \\
16 \\
73 \\
86 \\
\\
7 \\
78 \\
98\end{array}$ & $\begin{array}{l}47 \% \\
20 \\
12 \\
18 \\
28 \\
24 \\
74 \\
47 \\
10 \\
10 \\
11 \\
26 \\
11 \\
2 \\
33 \\
19 \\
\mathbf{2 5}\end{array}$ & $\begin{array}{l}4 \% \\
1 \\
4\end{array}$ \\
\hline
\end{tabular}


These tables, of course, are incomplete and do not tell the whole truth regarding the fruit diet of the birds, but simply summarize the results of observations and investigations as far as the records have been available. The records could be extended and the author would gladly welcome any additional data so as to make them as complete as possible.

A complete list of fruits eaten by some of the birds would probably include nearly the whole range of wild fruits; but in addition to the list already given, there are some other fruits which birds have been known to eat: sweet gum, rose, poison ivy, nightshade, sassafras, dewberry, bearberry, crow-berry, black alder, wintergreen, gray birch, oaks, pines, and moonseed.

Relation of Birds and Fruits. - The brilliant colors of the wild fruits which warm the autumn and winter landscapes, and the extent to which birds feed upon these, suggest one of nature's great economies. In somewhat the same way that insects are attracted to flowers by their bright colors and strong odors, to secure their nectar and pollen for food, and then distribute the pollen to other flowers, so there is something of the same relation between birds and fruits. The birds are attracted to the shrubs by the bright colors of 
PLANTING TREES, SHRUBS, AND VINES 131

the fruits, to secure the fleshy mass as food; and in many cases the seeds are carried a considerable distance and then left in various ways; either by being dropped accidentally or ejected from the mouth or crop, or by being unaffected by the digestive juices as they pass through the alimentary canal, so that they still retain their vitality after being ejected. Opportunity is thus given the plant to germinate its seeds under favorable conditions at a distance from the parent plant, and thus its range is extended. There is undoubtedly much to be learned along this line from a field study of the food-habits of birds during the autumn and winter.

An examination of these lists of birds and fruits gives some idea of the variety of fruit eaten by various birds; and the columns in the table showing the percentage of wild and cultivated fruit give an idea of the quantity of fruit eaten. In general those birds which eat the greatest variety of fruit are the ones which eat the largest quantities. Thus a comparison of these two features may give one a fairly good idea regarding the birds that will be attracted by various fruits.

Most Desirable Fruits. - It is a matter of quite common observation that on the whole the best single tree to plant is the mulberry, either the 
white or Russian, although the variety seems to make but little difference. It begins to bear early, and its fruit-bearing season is well prolonged. Among the vines it is noted that the Virginia creeper is a favorite. Prof. H. A. Surface writes : "If we should be obliged to make a selection of only four of these, it would be as follows: (1) an early sweet cherry, (2) the service-(June-)berry, (3) the mulberry, (4) the Virginia creeper."

From a study of the column showing when the various fruits ripen, one may select such a series as to give a succession of fruits through the whole season, beginning in the spring and extending even through the winter.

Plants for Ornamentation. - The plants which we set out to attract the birds may also serve the purpose of ornamentation. Among our vines the Virginia creeper, which is a favorite with the birds, is one of the most beautiful of all the vines for decorative effects. Shrubs may be chosen which hold their berries during the winter, thus furnishing the birds with food when it is specially welcome and also adding greatly to the winter landscape by their bright and attractive colors. Some of the shrubs which carry their fruits through a part or the whole of the winter are holly, barberry, bayberry, mountain-ash, black 
PLANTING TREES, SHRUBS, AND VINES 133

alder, greenbrier, red cedar, sumac, hackberry, bittersweet, burning bush.

Protection of Cultivated Fruits. - For the fruit-grower the planting of the proper trees and bushes for food may fulfill a very practical purpose, because these wild fruits will serve as a protection for the cultivated fruits, as the birds which sometimes eat cultivated fruit will usually take the wild in preference; and furthermore while the birds are eating this fruit they will also feed upon the injurious insects which may be near. It is important therefore to the fruit-grower that he should make a selection of those fruits which will begin to ripen a little before the cultivated fruit he wishes to protect, and remain in fruit till these have all been picked.

The larger fruits, such as apples, pears, and peaches, are not injured to any great extent by the birds. The smaller fruits, such as cherries, strawberries, raspberries, and blackberries, are the ones which may sometimes be destroyed by them. To protect cherries and strawberries, one may plant Russian mulberry and June-berry. Mr. Forbush thinks that the Charles Downing mulberry is even better than the Russian, as a tree to attract birds and keep them away from the cherries. It is a quick grower. The fruit is bighly colored, 
large, very early, and edible for man. He writes that where the harder varieties of cherries are grown near these trees, the birds do not seem to trouble the cherries at all.

As another method of protecting fruit, on the side of the orchard or strawberry-patch one may plant a row of some soft, sweet, early variety, to be left unpicked purposely for the birds, which seem to prefer those varieties to those which man deems more valuable.

Mr. G. T. Powell planted a row of Governor Wood cherries along one side of his orchard, especially for the birds, and notes the following results: "I have now bird-cherries by the bushels to spare, and the birds are working on them, but leaving untouched my choice varieties, such as the Montmorency and Richmond. These I am now selling at an extra price, because they are entirely uninjured, while my neighbors, who have not provided for the birds, are forced to sell their cherries at a discount because they are injured."

Toprotect raspberries and blackberries, one may plant mulberry, choke cherry, and elder. Some early, sweet variety of these berries may also be left as suggested for cherries and strawberries. Grapes may be protected by planting elder, Virginia creeper, and black cherry. 
Annuals. - There are also some annuals which may be grown to attract birds. A row of sunflowers at the back of the garden may be visited by goldfinches or others of the finch family. Goldfinches may also eat the seeds of the blue cornflowers. The hummingbird may be attracted by bright flowers with deep tubes. The bird prefers either red or orange flowers. Some of its favorite flowers among wild plants are coral honeysuckle, painted-cup, columbine, jewel-weed, Oswego tea, cardinal-flower; and among cultivated plants, columbine, scarlet salvia, trumpet-creeper, beebalm, nasturtium, gladiolus, horse-chestnut.

The following interesting account is given in "Bird-Lore," by Caroline G. Soule : Hummingbirds were frequent visitors to the flowers of a trumpet-creeper situated near a house. An imitation flower was made by painting a piece of paper and bending it into the required shape. Inside of this was placed a small bottle filled with sugar and water. This artificial flower was tied to the vine and was visited at once by the birds, and indeed such preference was shown for it that it was necessary to fill the bottle twice a day. On one occasion the bird came to this artificial flower while it was held in the hand. 


\section{CHAPTER VI}

\section{BIRD-PROTECTION IN SCHOOLS}

Values of Bird-study. - The values of birdstudy in its influence on child-life are many. It has a practical value in showing the great economic service which birds render man, as a result of which knowledge the child will become a more serviceable citizen; it has a training-value in teaching the child to become an accurate observer, as a result of which his later mental development will be more complete; it has a very distinct æsthetic value, as a means of arousing an interest in nature, which may form a life-long source of enjoyment, in which respect it is excelled, perhaps, by no other subject in its possibilities; and finally the study of bird-life has a moral value in broadening the sympathies of the child and developing a spirit of kindness and thoughtfulness toward all living things. A subject full of such possibilities is certainly worthy of more than passing notice in our school system.

Bird-protection. - To interest the children in birds is also the most permanent way of fur- 
thering bird-protection. One may almost say that only through instruction in the schools will eventually come that enlightened public opinion which will insure permanent and effective bird-protection. The necessity of having bird-study generally introduced into the schools, as a part of nature-study, cannot be too strongly emphasized. The importance of this is recognized by such organizations as the Audubon Societies, which are doing a splendid educational work. The protection of our native birds is an economic question of such importance that our school system must be utilized to solve the problems which arise in this connection. In the hands of the school teacher lies the solution of this and other economic problems of the day. The children should be taught the value of birds and encouraged to protect them. This may be accomplished in a positive, not a negative way ; that is, the children are to be taught not merely that they must not injure the birds and rob their nests, but also that they are to do something for the birds, - protect them, feed them, build houses for them, and be kind to them.

The Child's Activities.-One of the most effective phases of nature-study is that which calls into play the manual activities of the child in 
providing for himself opportunities for making studies of the life around him. This principle of utilizing the child's activities is one that is well understood and applied in the kindergarten, but too little employed in later years. It will prove a most effective instrument to be used with the children when circumstances allow. Bird-study is specially well adapted to make use of these activities in building bird-houses for winter protection and spring nesting, and lunch-tables for feeding the winter birds, and in providing drinking fountains. The very fact that the child is doing something for the birds is a means of developing that helpful sympathy with nature which may prove such an important factor in all his subsequent life. And, furthermore, an excellent opportunity is offered for training the perceptive powers of children by watching the birds that may come in response to the attractions offered. These observations will be carried on with much greater ardor and thoroughness because the child has himself helped to furnish the conditions which make his observations possible.

\section{Building Nesting-houses}

Manual Training. - The construction of these houses and lunch-counters may be carried on at the home, or it may naturally be correlated 


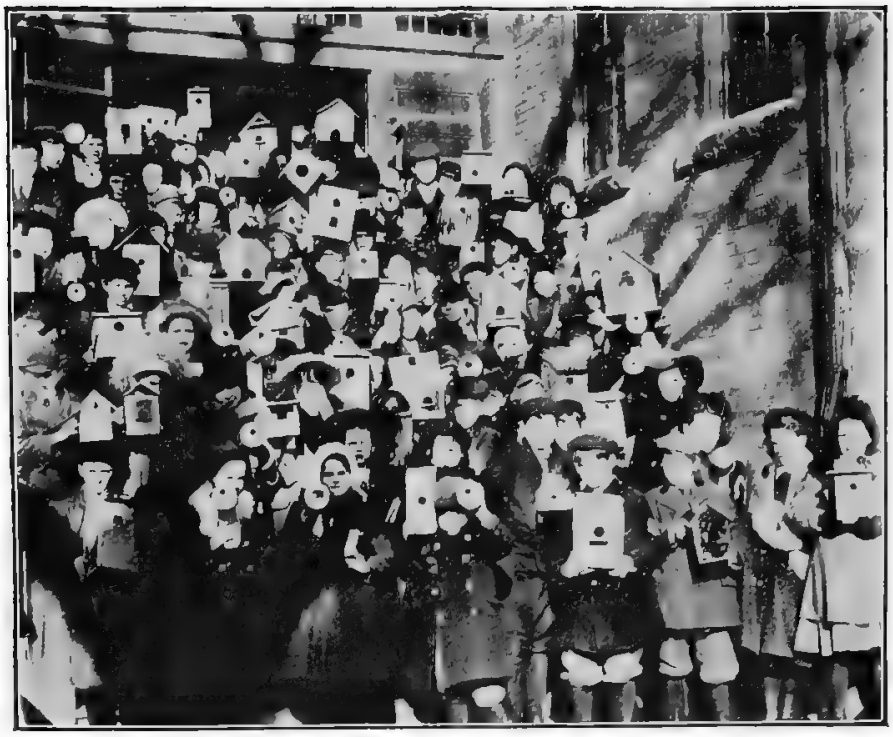

CHILDREN OF LINCOLN SCHOOL, PASSAIC, N. J, WITH BIRD-HOUSES

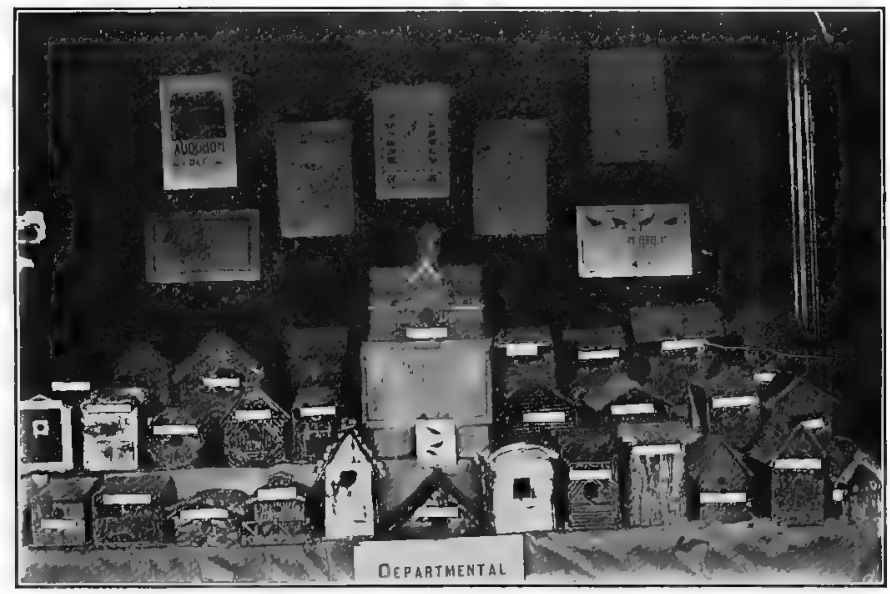

BIRD-HOUSES MADE BY CHILDREN OF PUBLIC SCHOOL No. 5, BRONX, NEW YORK CITY 

with the work in manual training, as is being done in some cities. Mr. Finley, a field-agent of the Audubon Societies, writes from Oregon: "We have a great deal of interest in bird-study worked up in various schools about the state. Wherever there is a manual-training school they are making many bird-houses." Superintendent Alderman, of Eugene, Oregon, writes that while he was county school superintendent of Gamhill County he encouraged the children of the manualtraining department to build bird-houses, which they did to the extent of over one thousand. With reference to the work in Eugene be writes: "As a result of a little encouragement, the children brought in for inspection 334 birdhouses. They filled three rooms of the Eugene High School. Almost every yard has a birdhouse in it now. Birds build in most of the houses. The notes the children kept of the selection of the house, etc., were made the basis of the language work. The children were warned not to let the English sparrow build in the houses. The following birds built in the children's houses: violet-green swallow, bluebird, wren, chickadee. The civilizing effect of birdstudy upon the children is at once evident. It is the finest training in observation that I know of." 
In the School of Education of Chicago University, a new method was adopted in the claywork department, of modeling bird-houses from clay, the work being done by the children in the sixth grade. (See description, page 22, and illustration opposite page 22.)

But whether the work is done in the manualtraining department or not, there will be little difficulty in arousing the interest of the children sufficiently so that they will build bird-houses and bring them to school for inspection. The matter may be brought to the attention of the children early in the winter, because the houses may serve as a shelter for the winter birds; but the children will probably be more enthusiastic in the early spring, when there is a more immediate prospect that the houses will be occupied.

Method in the Schoolroom. - The subject should be introduced by a general discussion of those birds which nest in hollow trees or other cavities. The children should be asked to search the neighborhood to ascertain to what extent those natural nesting-sites can be found. In many localities these have been entirely cleared away in the development of the land for real-estate purposes, and thus may be urged the necessity of building bird-houses if we would keep up the 
numbers of these birds. The problems which arise in connection with the construction and location of bird-houses should be talked over with the children and the important precautions to be observed explained as discussed in Chapter II. The really essential features having been made clear, the children should be allowed to use their ingenuity and individuality about arranging other details.

Difficulties. - The children should understand the difficulties to be met, so as to avoid undue disappointment, and should be prepared to overcome them so far as possible. The greatest obstacle of all will be the English sparrow. Some devices which may assist in keeping this bird away have been discussed in Chapter II, the most effective one of which is to make the hole so small that the sparrows cannot enter, but large enough for the wren and chickadee. With bluebirds' and tree swallows' houses probably the most effective thing which the children can do is to make the houses so that the top may be easily lifted, and then to remove the eggs of the sparrow once a week or as fast as they are laid. But in no event should the sparrow be allowed to rear young. If nothing else can be done, the entrance holes should be covered, or the house 
taken down, as soon as it is evident that no other bird is going to use the house. Of course killing the sparrows cannot be recommended to the children. Whatever is done in this line must be left to the adults.

If the school building is favorably located, houses should be put up in the school-yard. These should be of types adapted to the different species of birds, so as to attract as many kinds as possible. If these are occupied, opportunity will be furnished the whole school for bird-study.

It would be well worth while to see if the park boards would not coöperate with the schools, so that the children might make a large number of houses and place them in the parks. In the spring of 1906 such a plan was tried in Jackson and Washington parks, Chicago, the children making several hundred bluebird and wren houses.

If the children's bird-houses at home are occupied, they should be encouraged to make frequent reports on what they observe. The children should be strongly cautioned not to examine the houses closely after the birds once begin to build, because they are easily frightened away. The teacher should not ask for any observations which require a close examination of the house during this period. After the young are hatched, the box may be inspected more closely, but the young should 
not be handled. The children will be so anxious to report that they will not need much encouragement, but some directions may be given to guide their observations. The following suggestions for studying bird-tenants are given in "Bird-Lore," by Mr. T. Gilbert Pearson, who has charge of the department "For Young Observers": -

"If those young observers who put out birdboxes this spring will watch closely, they may see many new and delightful things happen when the birds come to make their nests in them. Let me suggest that each of you have a note-book and keep a diary of what takes place about the birdbox. When you once begin this, there will be so many things to write down that you will find it hard to know just what to include in your notes. In order to guide those who may be interested in keeping a note-book, I am going to ask some questions, which, if you can answer correctly at the end of the summer, will show that you have made a good study of the birds you have been watching. With this information all carefully preserved in your note-book, you will be able to write an article for the 'Young Observers' department, and thus let us all share something of the pleasure which has been yours during the days when you so carefully watched the pair of bright birds flying daily about your home. 
"POINTS TO BE NOTED

"1. What date did the birds first appear in your box?

"2. What kind of birds chose the box for their home? Did any other species attempt to drive them away?

"3. When did they first begin to bring material for the nest, and how many days before they ceased to perform their work?

"4. What time of the day did the birds work most at their task, and how early in the morning and late in the evening did you see them thus engaged?

"5. Did the male and female both build the home? if not, which one appeared to be the most active in the work?

"6. How many days passed after the birds stopped carrying nesting-material before the eggs hatched?

“7. How often were the young fed between eight and nine o'clock in the morning and four and five o'clock in the afternoon on two different days? Did both birds feed the young, and could you tell what they fed them?

"8. How many days after the eggs hatched before the young left the nest?

"9. Did the young know how to fly at once 
upon leaving the nest, and do you think the old ones taught them to fly?

"10. When the birds have left the nest not to return again, take out the nesting-material and see of what it is composed. How many feathers, twigs, strings, pieces of grass, or other articles did it contain?"

As an illustration of the constant and accurate observations made possible by having the birds nest at one's door are given the following records kept by Master Edward Uehling, of the Passaic, N. J., Schools : -

\begin{tabular}{|c|c|c|}
\hline \multirow{3}{*}{$\begin{array}{l}\text { Began to build } \\
\text { 1st egg laid }\end{array}$} & \multirow{2}{*}{$\begin{array}{c}\text { Bluebird } \\
\text { April } 17\end{array}$} & House Wren \\
\hline & & May 8 \\
\hline & " 24 & “ 16 \\
\hline $2 d " 4$ & “ 25 & 17 \\
\hline $3 d " 6$ & " 26 & 18 \\
\hline 4th " " & & 19 \\
\hline 5th " & & 20 \\
\hline 6th " " & & 21 \\
\hline 7th " " & & " 22 \\
\hline Young hatched & May 11 & June 4 \\
\hline “ left nest & & “ 21 \\
\hline
\end{tabular}

\section{Feeding Winter Birds}

The introductory work to feeding the winter birds should be done in the late fall, as it is important that food should be provided early to secure the greatest returns in attracting the birds. A talk on the food of birds may be given so as to bring out the two classes of foods for birds, the 
animal and vegetable. The purpose of this talk should be, first, to show the children the kind of food to be provided; second, to show that much of the food of the birds is covered by snow and ice. Suggestions should be given regarding the best kinds of food to be used and the best ways of putting it out (for a discussion of which see Chapter III). The necessity of providing a constant supply of food should be emphasized, and also of seeing that there is a food-supply immediately following snowstorms. It will be well to remind the children each week about the foodsupply, so that they will not forget it. The children will become enthusiastic over the prospect of taming the birds sufficiently to feed from the hand. The construction of moving lunch-counters, as suggested on page 94 , may be made a part of the manual-training work, as well as the building of bird-houses. This kind of counter is especially recommended to the children for its conveviences, as being easily kept provided with food, as being a partial protection against the English sparrow, and as furnishing a means of gradually taming the birds.

Shelter. - And not only should the children be encouraged to provide food, but some places of shelter as well. The bird-houses intended for 
nesting-sites may serve this purpose, or a more open box with back toward the storms may be placed in some sheltered spot.

And while the children are being encouraged to feed the birds at home, a lunch-counter should be provided in the school-yard if the conditions will allow it. The following suggestions regarding such a table are given by Mrs. M. O. Wright in "A Year With the Birds": -

\section{"A SCHOOL-YARD RESTAURANT}

"As you have already learned, some birds eat insects and others seed-foods; or, to put it in another way, some birds prefer meat and some bread; so if you wish to suit all kinds you must feed them with sandwiches, made of both bread and meat.

"'Sandwiches for birds!-how foolish!' I hear some one say. Stop and think a moment, and you will see that it is merely a way of expressing, a figure of speech, as it is called.

"Give the birds the material, crumbs, cracked corn, hayloft sweepings, bits of bacon, suet, or bones that have some rags of meat attached, and they will make their own sandwiches, each one to his taste.

"If this food is merely scattered upon the 
ground it will attract mice, rats, and other rodents, but if a regular lunch-counter is prepared for the food, you will find that the birds will appreciate the courtesy, become liberal customers and run up a long bill; this, however, they will pay with music when spring comes.

"A SUGGESTION FOR THE LUNCH-COUNTER

"Every school has its flag-pole, and, while some are fastened to the building itself, many stand free and are planted in the yard.

"Around this pole a square or circular shelf about eight inches wide can be fastened, four feet from the ground, and edged with a strip of beading, barrel-hoops, or the like. A dozen tenpenny nails should be driven on the outside edge at intervals, like the spokes to a wheel, and the whole neatly painted to match the pole.

"Then each week one child should be appointed as Bird Steward, his or her duties being to collect the scraps after the noon dinner-hour and place them neatly on the counter, the crusts and crumbs on the shelf and the meat to be hung on the spikes.

"Nothing will come amiss - pine-cones, beechnuts, the shells of hard-boiled eggs, broken fine, apple-cores, half-cleaned nuts; and if the children will tell their parents of the counter, they 
will often put an extra scrap or so in the dinnerpail to help the feast. Or the fortunate children whose fathers keep the market, the grocery-store, or the mill, may be able to obtain enough of the wastage to leave an extra supply on Friday, so that the pensioners need not go hungry over Sunday.

"All the while the flag will wave gayly over the little Citizen Bird, as under its protection it feeds on its human brother's bounty."

In case any efforts are made by adults in the neighborhood to feed systematically those birds which do not come close to buildings, such as the quail and partridge, the older boys of the school should become enthusiastic assistants in helping to clear away the snow at the feeding-stations, and provide fresh supplies of food.

The following suggestions are given to direct the children's observations of the winter birds :-

1. Try a variety of foods and note what kind of food is eaten by each species and what kind each seems to prefer. Does each kind of bird eat both vegetable and animal food, or confine itself to one kind? What birds eat the greatest variety of foods? Which birds will eat suet from a treetrunk? 
2. How do the various birds approach the counter? Do they give any warning of their coming by giving any call-notes?

3. After reaching the counter, note their actions. Do they stay on the trough and eat the food, or do they fly away with it first?

4. Do the birds all crack seeds in the same manner?

5. At what time in the morning are the first visits made, and at what time in the afternoon the last?

6. Which birds seem to visit the counter most frequently during the day? Which least frequently?

7. Make a list of birds in accordance with the degree of tameness which they show, placing the tamest first. Which ones will come to the windowsill? Do any become so tame as to feed out of the hand?

8. How early in the season do the birds begin to feed? Which come first? How late in the spring do the birds continue to come? Which remain the longest?

9. Do any of the migrating birds in the spring come to feed?

10. Make a list of the birds in the order of fear shown toward other birds, placing first those which are not driven from the trough by the 
approach of other birds and last those most easily driven away.

11. Occasionally an individual bird has some peculiar marking by which it may be recognized. If you find any of this kind, make a special study of that individual, noting in what ways he differs from other individuals of the same species.

12. In what kind of weather do the largest number of birds come to feed?

13. Toward night, watch the bird-houses or shelters that you may have provided and see what birds use them.

The observations made both on the winter birds and on those that nest in houses may well serve as the foundation for much of the language-work. The children will take hold of the work with much more zest and interest because it is based upon something which they have actually seen and done.

English Sparrow. - The great difficulty to be met here, as with bird-houses, is the English sparrow. But the ill results may be less noticeable here than with the bird-houses, for only one pair can nest in a house, while many birds may do their feeding at a counter, if not at the same time, then at different times during the day. But the gen- 
eral effect of the sparrows is to drive other birds away, for they congregate in flocks even when they are not feeding. Some suggestions as to how this difficulty may be partly met in the construction and location of the counters have been given in Chapter III, but of course the children should not attempt the methods of poisoning or trapping explained there. This should be left for adults.

While the two methods of attracting birds discussed in this chapter are the ones best adapted for school use, something may also be done in the line of encouraging the children to provide drinking-fountains and of instructing them how to make the fountains. The planting of trees and shrubs requires so long before the returns come in, that this method of attracting the birds will not appeal strongly to the children, but they may be encouraged to plant a row of hemp, Japanese millet, or sunflowers, to attract the goldfinches, and to furnish a supply for the winter lunchtable.

Bird-fountain in a School-yard. - In some cases it may be practicable to construct a birdfountain in the school-yard, which may thus provide an opportunity for the children to study the habits of the birds which visit it, and may furnish 
an incentive and object-lesson for the children to construct a fountain at home. Such a fountain was constructed a few years ago in a school-yard at Worcester, Massachusetts, under the supervision of Miss Edna R. Thayer. The money was raised by the children in various ways, the entire cost of the fountain being twenty-two dollars and fifty cents. The fountain was made on the same plan as that described by Dr. Hodge (pages 120, 121). Wild flowers were planted in the crevices of the fountain and at its base, and clumps of shrubbery were set near so that their fruit might furnish food for the birds. Connections were made so that running water dripped into the basin, and a drain carried off the surplus water. The first year that the fountain was built it was visited by twenty-five species of birds before school closed in June.

Some of the results of this fountain are thus set forth by Miss Thayer in "Primary Education":-

"Without a suggestion from any one several of the older boys and girls copied the birdfountain idea at their homes. Some placed pans of water in the midst of a pile of stones, with plants filling the spaces between them, the pan to be emptied each day; while one boy connected a length of old rubber hose to his pan, thus securing a constant supply of cool, fresh water. 
"And so the bird-fountain seems to have been a happy thought for our school. The children have learned to know the birds and their habits with a sympathetic and protective interest which could never have been aroused had they not had a personal share in helping and caring for their little feathered neighbors."

A fountain on the same plan has recently been constructed in the yard of Franklin School, Passaic, New Jersey. The children were given a talk on bird-fountains and shown pictures of the one at Worcester, and asked if they would like to have a similar one in their own yard. Under the enthusiastic guidance of Miss Lees, the principal, the children contributed liberally, so that, after paying for the fountain and the shrubs and other plants set around it, there was a small surplus left. The stones used in the construction of the fountain were rough pieces of red sandstone, obtained from neighboring excavations, and matching the foundation and trimmings of the school building. The fountain has been finished so recently that there has not been sufficient time to report any results. (See illustration, page 118.) 


\section{CHAPTER VII}

\section{BIRD-PHOTOGRAPHY}

THe purpose of this chapter is to call the attention of the reader to the splendid opportunity offered for taking pictures of those birds which may be attracted around our homes, and to give a few general suggestions regarding the equipment needed and the method of using it. No attempt will be made to treat this subject from a professional standpoint, for the author is but an amateur in this work and does not anticipate that he will be able to contribute much to those who have already had experience in bird-photography, except as another's experience may prove of interest; but to those who have never taken the first step in the fascinating art of bird-photography, perhaps these experiences may prove suggestive.

From the time when the author first became interested in bird-life he looked forward with much anticipation of pleasure to the time when his bird-studies might be pursued with a camera, but the great expense which he had understood was involved in securing the proper equipment 
seemed to postpone for some time the fulfillment of these desires. It was, therefore, with much gratification that the following statement was found in Job's "Among the Water-Fowl": "An expensive outfit is entirely unnecessary. In case my own experience may prove an encouragement, let me say that all my pictures in this book were taken with an ordinary 4 × 5 focusing camera, rapid rectilinear lens, and bellows of 12 inches draw, that cost me less than $\$ 20 . "$

Thus encouraged at the possibility of securing the necessary outfit at a small expense, inquiries were made, and through a friend, attention was called to a second-hand outfit adapted to birdphotography, which was secured for about twenty dollars, and which proved fairly well fitted for the purpose. It was a $5 \times 7$ camera, which is too large and heavy for field work. In this has been used a kit and $4 \times 5$ plates altogether. A $4 \times 5$ camera is better adapted to bird-photography, as it is very seldom that one needs a larger plate, and in tramping through the country the larger size is quite a burden on a hot summer day.

Kind of Camera. - As birds are comparatively small objects, it is necessary for the camera to be placed quite near the object to be photographed in order to secure a sufficiently large 
image; for this a long draw of bellows and a long focus lens are needed. They are the only absolute requisites. Other improvements which can be secured without much additional expense are the reversible back and the swing back, the first of which will come into frequent use and the second into occasional use in photographing nests; but they are not essential.

Another device which the author has found such a constant convenience and time-saver as to be almost indispensable is a ball-and-socket attachment to go on the tripod to which the camera is to be attached. This allows the camera to be pointed almost instantly in any direction, and frequently when quick work is demanded may be the means of securing a picture which might otherwise be lost, and in all cases it is a wonderful convenience.

Incidentals. - Another device, which under certain conditions may be so essential that without it no photographs can be secured, is a steel rod about a foot long and three eighths of an inch in diameter. At one end it tapers and is provided with threads so that it can be screwed into any tree or post. Near the other end is a plate three inches in diameter, with a hole in the centre, allowing the camera and ball-and-socket 
attachment to be securely fastened to the plate. To illustrate the uses to which this may be put, two instances which happened last summer may be cited. A nest of a song sparrow was found on the ground. An attempt was made to spread out the legs of the tripod so as to get the camera down low enough, but it could not be arranged. So a post was driven into the ground near the nest, and then the screw was turned into the post and the camera attached. A little later in the season, an oriole's nest was found so high up in an old apple tree that it was almost impossible to attach the camera; so the screw was fastened to the largest limb and the camera attached to this. And many other cases will arise where this will be of great service.

Method of working Shutter. - While the birds will soon become accustomed to the nearness of the camera, some device is needed so that the operator may stand at a distance and work the shutter. This may be done by means of long rubber tubing, attached to the shutter, and through which air is forced with a bicycle pump, at the other end. As still another means, a piece of metal may be attached to the lever of the shutter, to lengthen it so that it will snap more easily; and to this may. be tied a piece of linen 
thread which may be passed around the focusing screw and then carried to any distance. The author uses a spool of ordinary linen thread, which enables him to retire to any distance desired. Each method has its advantages, the chief ones of the latter being perhaps the slight expense involved, the small weight to carry on field-trips, and the easy adaptability to any desired length. The advantages of the rubber tubing are that it is not disturbed by the wind and there is not the risk of the shutter's being operated accidentally that there is with the thread. The author has used the thread entirely in his work, and has found it on the whole quite satisfactory, though perhaps, everything considered, the tubing may be superior.

Time to photograph. - In order to approach a bird closely enough to photograph it, one must take advantage of some strong instinct, or feeling, which will offset the fear caused by the nearness of the camera. The two feelings which may be used to the best advantage are the parental instinct shown in rearing the young, and the feeling of hunger. Opportunity for using the former means is furnished by those birds which nest in houses; and for using the latter means by those which will come to the winter feast. 
Photographing Birds at Nesting-houses. It has been the author's experience that the birds which nest around buildings or come there for food have become so tame and accustomed to the proximity of human beings that they can be photographed with great ease. With both bluebirds and house wrens, almost as soon as the camera was in position the birds came to the nest, and it was necessary for the operator to retire only a short distance, and in some cases probably he might have remained at the camera. The opportunity offered of securing photographs with but little trouble is an excellent one. If the house is in a position difficult of access for setting up the camera, it may easily be lowered without alarming the birds, and then replaced in its first position after the pictures have been secured. The author has tried this with both bluebirds and wrens, and the feeding of the young went on as usual after the house had been changed, although in one case the male bluebird came much less frequently to the nest.

As a convenience in moving the house, the reader is referred to the method of putting up houses explained on pages 78 and 79. An observation box, made as suggested on pages 20 and 21, allows opportunity for photographing the young as well as the old birds. 
Photographing Winter Birds. - The pictures of most of the winter birds taken by the author were secured by placing the camera just inside the window, only a few feet from the lunchcounter, while the operator sat just back of the camera. There is a special degree of satisfaction in photographing winter birds, because one is not in any way interfering with the life of the bird or disturbing it in any way, and there is absolutely no possibility of accident, of which there is always danger in working with young birds; though this is more than compensated by the trust which the birds usually come to show in the operator.

During the winter of 1906-1907, the author had good opportunities for photographing the birds. His friend Master Uehling had arranged a moving counter as explained on page 94 , and soon most of the birds came to the window to feed. To secure pictures of those which would not come, or which came only occasionally, to the sill, food was scattered on the ground in a spot from which the snow had been removed. The camera was focused on the food and the thread run to the second-story window. The blue jays came occasionally to the window, but no good photograph of these birds was obtained here. Most of the work, however, was done at the win- 
dow, the camera being set up just inside, and incidentally it may be worth mentioning that during the bitter cold days it was most gratifying to be able to sit in a warm room while securing pictures. At first the window was kept open; but it was found that the double click of the shutter used frightened the birds sufficiently, so that most of the pictures were blurred. Accordingly the window was closed and pictures were secured with less difficulty, as the birds could not hear the noise of the shutter, and sometimes it was possible to change the plates and secure two pictures of the same bird before it left the counter.

During the winter photographs were secured of nine species: the chickadee, white-breasted nuthatch, downy woodpecker, brown creeper, blue jay, hermit thrush, myrtle warbler, junco, and song sparrow. This list includes all the birds that came to feed excepting the tree and white-throated sparrows, but these were both very rare visitors at this particular lunch-counter. Pictures of all these, with the exception of the junco, were secured at the window-sill. The chickadees became so tame as to feed from the hand.

Actions of the Different Species. - The various species of birds showed considerable differences in the way in which they seemed to regard 
the camera at first. After a little they became so accustomed to it that they came and went when it was present as when it was absent. The chickadees from the start paid no attention to it, nor did the thrush, creepers, juncos, or myrtle warblers; the nuthatches and blue jays showed quite a degree of caution, but the backwardness of the former was removed by closing the window, while the latter seemed willing to trust themselves within the range of the mysterious-looking object, only when driven by hunger. The downy woodpecker was the most obstinate of all, always eying the outfit suspiciously, with a swinging motion of his body from side to side; and even when he was within range of the camera he was so quickmotioned that the pictures were nearly all spoiled. It was only during the latter part of the winter that he became sufficiently reconciled to the presence of the camera so that a respectable picture was obtained.

The hardest chase of all was given by the brown creeper, not because he was alarmed at all at the camera, but on account of his peculiar habits. He seldom came more than two or three times a day to the trough, and when he did come it was in such a quiet, unobtrusive way, giving absolutely no warning of his approach, that unless one kept constant and close watch on the trough, he might 
come and go before his presence was detected. It was only by keeping the camera set up for hours at a time and keeping unremitting watch of the shelf that any pictures were secured. The author would hardly dare to tell the number of hours spent in securing pictures of the creeper and downy woodpecker.

As a means of securing pictures of tree-trunk birds in their natural position, a branch of an old apple tree was attached vertically to one side of the window and a piece of suet nailed to the branch, all other food being removed from the trough. In this way pictures were secured of the downy and the creeper, the white-breasted nuthatch and the chickadee. The first two sidled their way up the branch to the suet, and just as the shutter was pulled, the former dodged his head into his own shadow, and the creeper zigzagged at the last moment away from the suet instead of toward it, thus blurring the picture a little. The nuthatch climbed up above the suet, and then, turning around in his characteristic position, head downward, pecked at it; while the chickadee alighted with both feet on the suet, and partook of the feast in any position that pleased his fancy at the moment. 


\section{APPENDIX}

Ligt of those to whose Contributiong the Adthor has had Access or who have fornighed Information throdgh Pergonal Correspondence.

Alderman, L. R., Eugene, Oregon.

Allen, J. C., Hackettstown, N. J.

Ayers, M. A., Fitzwilliam, N. H.

Ayres, Mary A., Medford, Mass.

Ball, Jennie C., Oakville, Conn.

Baynes, Ernest Harold, Meriden, N. H.

Beal, F. E. L., Washington, D. C.

Bergtold, Dr. W. H., Denver, Col.

Bixby, H. S., Plattsburg, N. Y.

Black, Isabel C., York, Pa.

Blanchan, Neltje (Mrs. F. N. Doubleday, New York).

Bole, Marion.

Bond, Frank, Washington, D. C.

Bonner, Mrs. Paul R., Stamford, Conn.

Bowdish, B. S., Demarest, N. J.

Bowen, Mrs. Carroll E., Rochester, N. Y.

Brewster, William, Cambridge, Mass.

Brown, Clarence D., Rutherford, N. J.

Brown, Edwin C., Minneapolis, Minn.

Bruen, Frank, Bristol, Conn.

Burns, Frank L., Oberlin, Ohio.

Cairns, F., Washington, D. C.

Case, Bert F., Middle Haddam, Conn.

Chapman, Frank M., Englewood, N. J.

Clark, Josiah. 
Cleaves, Howard H., Prince's Bay, N. Y.

Davenport, Mrs. Elizabeth B., Brattleboro, Vt.

Dike, A. C., Bristol, Vt.

Dolbear, Mary E., Tufts College, Mass.

Embody, G. C., Ithaca, N. Y.

Evans, Allen, Jr., Haverford, Pa.

Evans, Rowland, Jr., Haverford, Pa.

Finley, W. L., Portland, Oregon.

Fisher, Dr. A. K., Washington, D. C.

Forbush, Edward H., Westboro, Mass.

Francis, Sarah M., Elkhorn, Wis.

French, Mrs. W. M. R., Beverly Hills, Ill.

Gault, B. T., Glen Ellyn, Ill.

Grant, W. W., Summit, N. J.

Hansinger, Lelia E., St. Albans, Vt.

Hegner, Robert W., Ann Arbor, Mich.

Henshaw, H. W., Washington, D. C.

Hodge, Prof. C. F., Worcester, Mass.

Holmes, Mrs. Georgiana K., Summit, N. J.

Holtz, Fred L., Brook]yn, N. Y.

Horton, Wm. C., Brattleboro, Vt.

Hunt, Richard M., Winchester, Mass.

Ives, Ella G., Brookline, Mass.

Jackson, Anne W., Jacksonville, Ill.

Jackson, William M., Campbellsville, Ky.

Jacobs, J. Warren, Waynesburg, Pa.

Kauffman, Rebecca H., Oregon, Ill.

Lacey, Lottie A., Southport, Conn.

Lange, D., St. Paul, Minn.

Lord, Rev. William R., Dover, Mass.

Luther, Ella, Lake George, N. Y.

McLemon, Isabel, Englewood, N. J.

Mead, E. M., New York City.

Menke, H. W., Aurora, Wyo. 
Merriam, Florence A. (Mrs. Vernon Bailey, Washington, D. C.)

Oberholser, Harry C., Washington, D. C. Pearson, T. Gilbert, Greensboro, N. C.

Pellett, Frank C., Atlantic, Iowa.

Pennell, Elizabeth A., Brunswick, Me.

Robbins, Samuel D., Belmont, Mass.

Robinson, Daniel C., Manchester, Me.

Rogers, Ruth, Sherman, Conn.

Savage, W. G., Monteer, Mo.

Schantz, Orpheus M., Chicago, Ill.

Seton, Ernest Thompson, Cos Cob, Conn.

Shattuck, Gertrude A., Dorchester, Mass.

Sherman, Althea R., National, Iowa.

Sinnott, Edmund W., Bridgewater, Mass.

Smith, Harriet S., Berlin, Conn.

Soule, Caroline G., Brookline, Mass.

Stanley, Mrs. Mary R., North Attleboro, Mass.

Surface, H. A., Harrisburg, Pa.

Taylor, John W., St. Paul, Minn.

Ten Eyck, Elizabeth F., Lansing, Mich.

Torrey, Bradford, Newton Lower Falls, Mass.

Treat, Mrs. Mary, Vineland, N. J.

Uehling, Edward, Passaic, N. J.

Van Sant, F. A., Jay, N. Y.

Vredenburgh, Abbie, Curran, Ill.

Warren, E. R., Colorado Springs, Col.

Watkins, John, Calumet, Mich.

Webster, Laurence J., Holderness, N. H.

Welty, Dr. E. J, Portland, Oregon.

Widmann, Otto, St. Louis, Mo.

Woodcock, J., Minnedosa, Manitoba.

Wright, Mrs. Mabel Osgood, Fairfield, Conn. 



\section{INDEX}

Adaptability of birds, 13.

Blackbird, Crow, eating fruit, 129.

Blackbird, Red-winged, eating fruit, 129.

Blackbird, Yellow-headed, feeding in winter, 87.

Bluebird, nesting-house for, 26; tamed to eat from hand, 84.

Box, observation, 19 . See also Houses.

Camera for bird photography, 156.

Cardinal, eating fruit, 129; feeding in winter, 87 .

Cat, fences to keep out the, 63; outwitting the, 61 ; traps for the, 63.

Catbird, eating fruit, 129.

Ceảdr-bird, eating fruit, 129.

Chickadee, eating fruit, 129 ; feeding in winter, 87; nesting-house for, 26 ; tamed to feed from hand, 84.

Chickadee, Carolina, 28.

Covers for nesting-houses, 23.

Creeper, Brown, feeding in winter, 87.

Crow, eating fruit, 129; feeding in winter, 87.

Crow, Clark's, feeding in winter, 87.

Cuckoo, eating fruit, 129.

Duck, Wood, nesting-houses for, 28.

Farm, value of birds on, 6 .

Feeding birds, effect of, 5 .

Fence, cat-proof, 63.

Finch, Gray-crowned Rosy, feed $\mathrm{ng}$ in winter, 87.

Finch, House, nesting-hasses for, 20.
Finch, Purple, eating fruit, 129.

Flicker, eating truit, 129; feeding in winter, 87; nesting-houses for, 30.

Flycatcher, Crested, nesting-houses for, 31 .

Food, in box, 92; in cocoanut, 92; on ground, 90 ; on tree shelf, 90 ; on tree trunk, 90; on window shelf,91; on moving shelf, 93 ; plants for, 125 ; for winter birds, $80,88$.

Food-bell, 102.

Food house, 100 .

Food tree, 100 .

Fountain, essentials of, 116; Dr. Hodge's, 120; location of, 116; on lawn, 117; pans for, 119 ; in schoolyard, 152; visitors at, 122.

Fruits, eaten by birds, 128; birds that eat, 129; to plant, 132; protection of cultivated, 133.

Germany, experiments in, 7, 49, 99, 124.

Goldfinch, feeding in winter, 87.

Gourds, for nesting-houses, 22.

Grosbeak, Evening, feeding in winter, 87; tamed to feed trom hand, 84.

Grosbeak, Pine, eating fruit, 129; feeding in winter, 87 .

Grosbeak, Rose-breasted, eating fruit, 129; feeding in winter, 87.

Grouse, Ruffed, eating fruit, 129; feeding in winter, 87.

Tawk, Sparrow, in nesting-house, 32.

Nouses, bark, 16 ; board, 18 ; clay, 22 ; swinging, 68; time to put out, 24 ; in, 21 . 
Jack, Whiskey, feeding in winter, 87; tamed to feed from hand, 84.

Jay, Blue, eating fruit, 129 ; feeding in winter, 87.

Jay, Oregon, feeding in winter, 87; tamed to feed from hand, 84 .

Junco, eating fruit, 129; feeding in winter, 87.

Kingbird, eating fruit, 129.

Kinglet, Golden-crowned, feeding in winter, 87.

Lark, Shore, feeding in winter, 87.

Limbs, hollow, for nesting-houses, 15.

Longspur, Lapland, feeding in winter, 87.

Martin, attempts to reëstablish, 34; nesting-houses for, 37 .

Mockingbird, feeding in winter, 87.

Mortality among winter birds, 4 .

Mud for nests, 56 .

Nesting-houses, birds nsing, 14. See also Houses.

Nesting-material, kinds to expose, 65.

Nesting-sites, destruction of natural, 2; plants for, 124.

Nuthatch, Red-breasted, feeding in winter, 87; tamed to feed from hand, 84 .

Nuthatch, White-breasted, feeding in winter, 87 ; tamed to feed from hand, 84 .

Observations on bird tenants, 143.

Oriole, Baltimore, eating fruit, 129; nesting-material for, 56 .

Oriole, Orchard, eating fruit, 129.

Owl, Screech, feeding in winter, 87; in nesting-house, 40.

Pheasant, feeding in winter, 87. Phobe, eating fruit, 129; nestingshelf for, 54 .
Photographing, at nesting-houses, 160; winter birds, 161.

Plants, for food, 125; for ornamentation, 132; for shelter, 123.

Problems of bird-life, 11.

Protection of birds in schools, 136.

Quail, eating fruit, 129; feeding in winter, 87 .

Redpoll, feeding in winter, 87; tamed to feed from hand, 84 .

Restaurant, school-yard, 147.

Robin, eating fruit, 129 ; in nesting. house, 41 ; nesting-trays for, 53.

Schools, building nesting-houses in, 138

School-yard, feeding birds in, 147; fountain in, 152; nesting-houses in, 142.

Shelf on tree, 90 ; moving, 93 ; window, 91.

Shelter, for winter birds, 92; plants for, 98.

Siskin, Pine, feeding in winter, 87.

Sparrow, Chipping, nesting-material for, 66; tamed to feed from hand, 84.

Sparrow, English, poisoning, 107; protecting food from, 104; removing eggs of, 71 ; shooting, 76 ; trapping, 77, 106; in winter, 103.

Sparrow, Fox, eating fruit, 129; feeding in winter, 87.

Sparrow, Song, eating fruit, 129; feeding in winter, 87 .

Sparrow, Tree, eating fruit, 129; feeding in winter, 87.

Sparrow, White-crowned, eating fruit, 129; feeding in winter, 87.

Sparrow, White-throated, eating fruit, 129 ; feeding in winter, 87.

Starling, feeding in winter, 87 ; in nesting-houses, 42.

Suet-box, 92.

Swallow, Bank, eating fruit, 129.

Swallow, Barn, nesting-shelf for, 54.

Swallow, Eave, nesting-shelf for, 55 . 
Swallow, Tree, eating fruit, 129; | Winter birds, value of, 9 ; observanesting-houses for, 43 .

Swallow, Violet-green, nestinghouses for, 43 .

Swift, Chimney, artificial chimney for, 55 . tions on, 149.

Winter day with birds, 97.

Woodpecker, Downy, eating fruit, 129; feeding in winter, 87.

Woodpecker, Hairy, eating fruit, 129; feeding in winter, 87.

Taming birds to feed from hand, 84.

Tanager, Scarlet, eating fruit, 129.

Thrasher, Brown, eating fruit, 129.

Thrush, Hermit, feeding in winter, 87.

Thrush, Wood, eating fruit, 129.

Titmouse, Tufted, feeding in winter, 87; in nesting-houses, 44; tamed to feed from hand, 84.

Training, manual, 138.

Tree-trunk, food on, 90 .

Value of birds on farm, 6,9 .

Ventilation for nesting-houses, 22.

Vireos, nesting-material for, 56 .

Vireo, Red-eyed, eating fruit, 129.

Vireo, White-eyed, eating fruit, 129.

Warbler, Myrtle, eating fruit, 129; feeding in winter, 87 .

Woodpecker, Red-bellied, feeding in winter, 87.

Woodpecker, Red-headed, in nesting-house, 45 .

Woodpecker, Yellow-bellied, eating fruit, 129.

Woodpeckers, experiments with, in Germany, 49.

Wren, Bewick's, in nesting-house, 47.

Wren, Carolina, 62.

Wren, House, nesting-houses for, 45.

Wren, Parkman's, nesting-houses for, 47.

Wren, Vigors's, in nesting-house, 47.

Wren, Winter, feeding in winter, 87.

Young birds, feeding, 57. 




